
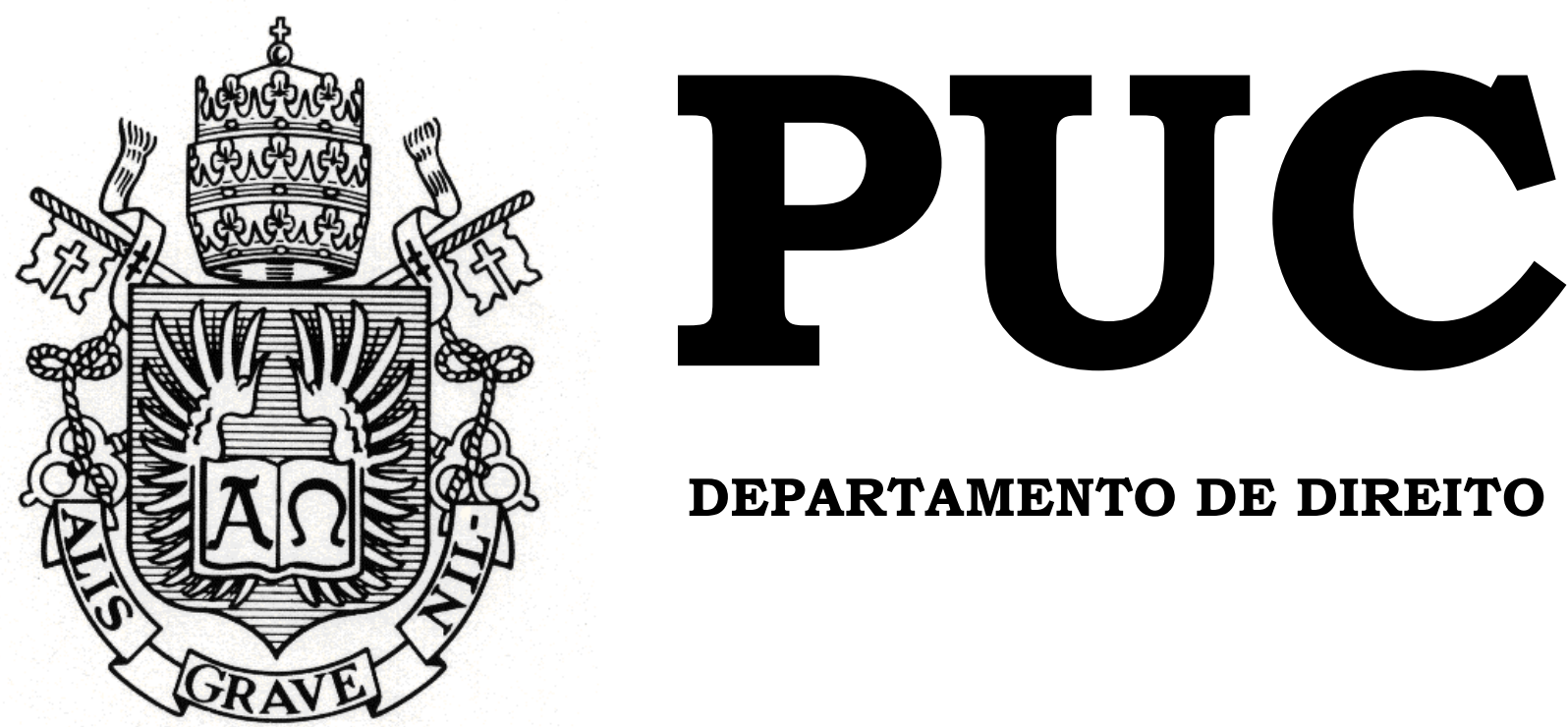

DEPARTAMENTO DE DIREITO

\title{
RESPONSABILIDADE CIVIL PELA PERDA DE UMA CHANCE
}

por

BRUNNA GABRIELLE MARONI REZENDE

ORIENTADOR: Marcelo Calixto

2014.2

PONTIFÍCIA UNIVERSIDADE CATÓLICA DO RIO DE JANEIRO

RUA MARQUÊS DE SÃO VICENTE, 225 - CEP 22453-900

RIO DE JANEIRO - BRASIL 


\title{
RESPONSABILIDADE CIVIL PELA PERDA DE UMA CHANCE
}

\author{
Por \\ BRUNNA GABRIELLE MARONI REZENDE
}

Monografia apresentada ao Departamento de Direito da Pontificia Universidade

Católica do Rio de Janeiro (PUC-Rio) para a obtenção do Título de Bacharel em Direito.

Orientador:

Marcelo

Calixto 
Sinceros agradecimentos a todos que me ajudaram, em especial, minha família, meus professores e meu orientador Marcelo Calixto, tornando possivel a realização deste trabalho. 


\section{RESUMO}

A presente monografia pretende elaborar uma análise acerca da responsabilidade civil pela perda de uma chance, com o intuito de explorar seus aspectos gerais e peculiaridades, além de sua aplicação no Direito brasileiro. A teoria, que teve origem na França, e foi também desenvolvida na Itália e nos países da Common Law, não possui previsão legal específica no Brasil. Recentes são também os estudos mais aprofundados sobre o tema realizados pela doutrina pátria. Examina-se, nesse passo, a manifestação da doutrina e da jurisprudência nacional, à luz de um novo paradigma solidarista, em que os danos injustos devem ser reparados. Analisa-se ainda a natureza jurídica da chance perdida, a sua relevância e seriedade, bem como a quantificação de sua indenização. Observa-se as modalidades de chances perdidas: em uma tem-se um dano autônomo e independente, e na outra, aplica-se a causalidade parcial, por meio de uma visão menos ortodoxa do nexo de causalidade. A chance séria e real, portanto, configura interesse jurídico, que deve ser indenizável.

\section{Palavras-chave}

Causalidade parcial.

Dano autônomo.

Dano emergente.

Dano extrapatrimonial.

Lucro cessante.

Nexo de causalidade.

Perda de uma chance.

Responsabilidade civil. 


\section{Sumário}

Introduçã̃o ......................................................................................................................... 7

Capítulo 1 - Pressupostos da Responsabilidade Civil .................................10

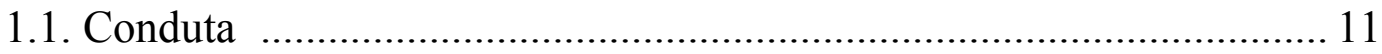

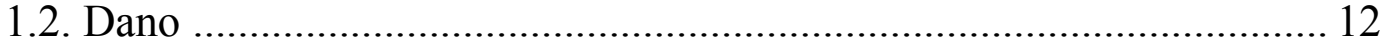

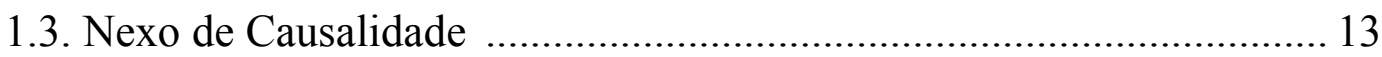

1.4. Teorias aplicáveis ao Nexo de Causalidade ......................................... 14

1.4.1. Teoria da Equivalência das Condições .............................................. 15

1.4.2. Teoria da Causalidade Adequada ..................................................... 16

1.4.3. Teoria do Dano Direto e Imediato ...................................................... 17

1.5. Outras Considerações ....................................................................... 18

Capítulo 2. Teoria da Perda de uma Chance ................................................... 18

2.1. Origem e Evolução Doutrinária............................................................ 18

2.2. A Perda de uma Chance e suas Modalidades …………………........ 23

2.3. A Perda de uma Chance como um Dano Autônomo ............................. 27

2.3.1. A diferença entre dano da chance perdida e os lucros cessantes ....30

2.3.2. Dano da chance patrimonial perdida e o dano moral ........................ 31

2.3.3. A Perda de uma Chance embasada na teoria da causalidade parcial 33

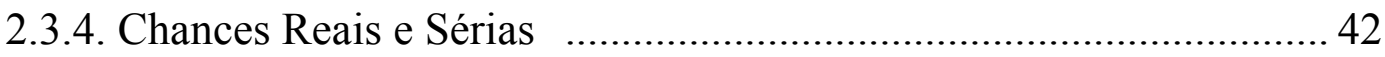

2.3.5. A quantificação da indenização decorrente da perda de uma chance

Capítulo 3. A Teoria da Perda de uma Chance no Direito Brasileiro .48

3.1. Manifestação da Doutrina .................................................................. 48

3.2. Compatibilidade da Teoria com o Ordenamento Jurídico Brasileiro... 52

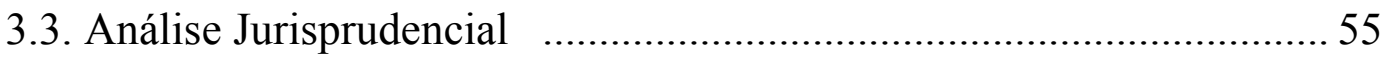

3.3.1. A identificação do prejuízo a ser reparado como dano moral ...........58

3.3.2. Equívocos na quantificação do dano a ser reparado ........................... 60

3.3.3. A mera possibilidade não pode ser indenizada .................................. 63

3.3.4. A Teoria da Perda de uma Chance no STJ ....................................... 72 
3.3.4.1. Os primeiros casos no STJ

3.3.4.2. O acolhimento da teoria - Leading Case Show do Milhão 75

3.3.4.3. A Consolidação da Teoria

Conclusão 


\title{
ABREVIAÇÕES
}

\author{
Art. - Artigo \\ Ag - Agravo de Instrumento \\ AgRg - Agravo Regimental \\ BTN - Bônus do Tesouro Nacional \\ Câm. - Câmara \\ CC - Código Civil \\ CF - Constituição Federal \\ Ed. - Edição \\ EDcl - Embargos de Declaração \\ Min. - Ministro \\ Rel.- Relator \\ REsp - Recurso Especial \\ STJ - Superior Tribunal de Justiça \\ TJ - Tribunal de Justiça \\ V. - Volume
}




\section{Introdução}

Vive-se em uma nova era cercada de incertezas e instabilidades. A evolução e progresso científico trouxeram novas tecnologias, novos valores, novas relações sociais e com isso, novas controvérsias jurídicas. Encontra-se portanto, em um novo paradigma ${ }^{1}$.

Nesse contexto, é possível perceber uma defasagem entre a rapidez na qual ocorrem as mudanças sociais e tecnológicas e a capacidade do Direito de acompanhá-las. Não são raras as vezes nas quais o Direito se encontra obsoleto perante uma nova situação jurídica.

O Direito Civil, desse modo, também é afetado pelo novo paradigma da pós-modernidade e com ele o instituto da responsabilidade civil. Portanto, teve o Direito Civil que passar também por uma evolução. Nessa vereda, cumpre aqui abordar a sua recente constitucionalização, após a promulgação da Constituição Federal em 1988.

Com o advento do novo texto constitucional, deixou-se de lado uma lógica individual e patrimonialista, fundada somente na tutela da propriedade e da autonomia privada, para predominar as situações jurídicas existenciais² ${ }^{2}$.

Destaca-se, nesse diapasão, o artigo $3^{\circ}$, inciso I, da Constituição Federal, que consagra o solidarismo e o artigo $1^{\circ}$, incisos III e IV, que promovem a dignidade da pessoa humana e os valores sociais do trabalho e da livre iniciativa, como fundamentos do Estado Democrático de Direito.

No instituto da responsabilidade civil, o princípio da dignidade da pessoa humana, a solidariedade social e a justiça distributiva, fizeram com

\footnotetext{
${ }^{1}$ MORAES, Maria Celina Bodin de. Danos à pessoa huamana:uma leitura civil-constitucional dos danos morais. Rio de Janeiro: Renovar, 2009. p. 60.

${ }^{2}$ MORAES, Maria Celina Bodin de. A constitucionalização do Direito Civil e seus efeitos sobre a Responsabilidade Civil. In: SOUZA NETO, Cláudio Pereira de; SARMENTO, Daniel (orgs). A constitucionalização do direito. Fundamentos Teóricos e aplicações especificas. Rio de Janeiro: Lumen Juris, 2007. Disponível em < http://www.estig.ipbeja.pt/ ac_direito/Bodin_n29.pdf>: p. 234
} 
que a tutela da vítima vigorasse, em detrimento do objetivo anterior de punição do responsável ${ }^{3}$, alterando toda a sistemática de reparação.

"O foco que tradicionalmente recaía sobre a pessoa do causador do dano, que por seu ato reprovável deveria ser punido, deslocou-se no sentido da tutela especial garantida à vítima do dano injusto, que merece ser reparada. A punição do agente pelo dano causado, preocupação pertinente ao direito penal, perde a importância no âmbito cível para a reparação da vítima pelos danos sofridos"4.

Posta assim a questão, assinala-se que, durante muito tempo, o dano decorrente de uma chance perdida, na qual a vítima teve retirada uma chance de auferir uma vantagem ou de evitar um prejuízo, por conta da conduta de outrem, não foi tutelado pelo Direito.

Diante da incerteza, da probabilidade, da álea, da chance, não sabia o Direito como lidar com tal situação. No entanto, com o progresso da ciência e do estudo das estatísticas, aliado ao já mencionado novo paradigma solidarista, foi possível enxergar um dano autônomo e independente na chance perdida, passível de reparação. Trata-se da teoria da responsabilidade civil pela perda de uma chance.

Primeiramente, essa foi discutida em países como França e Itália, pela doutrina e pelos tribunais, e também enfrentada pelos países da Common Law. Hoje, a teoria vem cada vez mais sendo estudada no país e aplicada pelas cortes brasileiras.

À vista de sua contemporaneidade e relevância social, optou-se por abordar o tema, sendo isso feito sob o seguinte enfoque: no Capítulo 1, será demonstrado os pressupostos da responsabilidade civil, dentre eles a conduta, o dano, o nexo de causalidade e suas teorias, de suma importância para melhor compreensão dos diferentes prismas da perda de uma chance.

No Capítulo 2, tratar-se-á da origem e evolução doutrinária do tema. Além disso, será estudado os principais aspectos da teoria da perda de uma chance, como suas modalidades, sua natureza jurídica, o reconhecimento da

\footnotetext{
${ }^{3}$ Ibid., p. 238.

${ }^{4}$ Ibid., p. 245.
} 
perda de uma chance como dano autônomo, a aplicação da causalidade parcial no tema e a quantificação do dano decorrente da chance perdida.

Por fim, no Capítulo 3, será enfrentada a teoria da perda de uma chance no Direito brasileiro, analisando-se a compatibilidade da teoria com o ordenamento jurídico pátrio e como os tribunais do país vêm a aplicando, por meio de extensa apreciação de sua jurisprudência. 


\section{Capítulo 1. Pressupostos da Responsabilidade Civil}

Antes de se adentrar o tema da responsabilidade civil pela perda de uma chance, escopo do presente ensaio, imperioso fazer um breve estudo acerca dos pressupostos básicos da responsabilidade civil.

Sobre o dever de reparar, assim afirma Sérgio Cavalieri Filho, em Programa de Responsabilidade Civil: "A violação de um dever jurídico configura o ilícito que, quase sempre, acarreta dano para outrem, gerando um novo dever jurídico, qual seja, o de reparar o dano." 5

A noção de responsabilidade civil está atrelada ao dever que alguém tem de reparar o dano causado diante de uma violação de um dever jurídico. Para Sérgio Cavalieri Filho, duas são as premissas basilares da responsabilidade civil:

"Primeira: não há responsabilidade, em qualquer modalidade, sem violação do dever jurídico preexistente, uma vez que a responsabilidade pressupõe o direito de uma obrigação. Segunda: para se identificar o responsável é necessário precisar o dever jurídico violado e quem o descumpriu"6.

O Código Civil de 2002, em seu art. 927, assim dispõe: Aquele que, por ato ilícito (arts. 186 e 187), causar dano a outrem, fica obrigado a repará-lo. Trata-se, cumulado com o artigo 186 do Código Civil ${ }^{7}$, da cláusula geral da responsabilidade subjetiva, aquela com culpa.

No entanto, o Código Civil de 2002 consagrou também a chamada responsabilidade objetiva, na qual haverá obrigação de reparar o dano, independentemente de culpa, nos casos previstos em lei ou quando se estiver diante de uma atividade de risco desenvolvida pelo Autor. A responsabilidade

\footnotetext{
${ }^{5}$ CAVALIERI FILHO, Sérgio. Programa de Responsabilidade Civil. p. 1.

${ }^{6}$ Ibid, p.5.

${ }^{7}$ Art. 186 CC. Aquele que, por ação ou omissão voluntária, negligência ou imprudência, violar direito e causar dano a outrem, ainda que exclusivamente moral, comete ato ilícito.
} 
objetiva encontra embasamento no parágrafo único do art. $927^{8}$, além do artigo $931{ }^{9}$ do Código Civil.

Dos dispositivos acima mencionados, pode-se inferir os pressupostos necessários para que ocorra a obrigação de reparação de danos. Para Silvio Rodrigues, os pressupostos da responsabilidade civil são a ação ou omissão do agente, a culpa, a relação de causalidade e o dano experimentado pela vítima. $^{10}$

Já Sérgio Cavalieri Filho entende como pressupostos da responsabilidade civil a conduta culposa, o nexo de causalidade e um dano, dispensando-se o elemento culpa quando se tratar de responsabilidade objetiva $^{11}$.

Para Fernando de Noronha, em Direito das Obrigações: Fundamentos do Direito das Obrigações: Introdução à Responsabilidade Civil, os pressupostos seriam o fato antijurídico, nexo de imputação, dano, nexo de causalidade e lesão do bem protegido. ${ }^{12}$

No presente ensaio, a despeito da divergência que se encontra na doutrina acima exposta, serão analisados os seguintes elementos: conduta, dano e o nexo de causalidade.

\subsection{Conduta}

Entende-se por conduta, "o comportamento humano voluntário que se exterioriza através de uma ação ou omissão, produzindo consequências jurídicas." $" 13$

\footnotetext{
8 Art. 927 parágrafo único. Haverá obrigação de reparar o dano, independentemente de culpa, nos casos especificados em lei, ou quando a atividade normalmente desenvolvida pelo autor do dano implicar, por sua natureza, risco para os direitos de outrem.

9 Art. 931 CC. Ressalvados outros casos previstos em lei especial, os empresários individuais e as empresas respondem independentemente de culpa pelos danos causados pelos produtos postos em circulação.

${ }^{10}$ RODRIGUES, Silvio. Direito Civil v.4, 17a edição, São Paulo: Saraiva, 1999, p.14.

${ }^{11}$ CAVALIERI FILHO, Sérgio. Op. Cit., p.5.

${ }_{12}$ NORONHA, Fernando. Direito das Obrigações: fundamentos do direito das obrigações: introdução à responsabilidade civil. v.1, São Paulo: Saraiva, 2003. p. 468/469.

${ }^{13}$ CAVALIERI FILHO, Sérgio. Op. Cit., p. 24.
} 
O supramencionado artigo 186 do Código Civil estabelece que qualquer pessoa que, por ação ou omissão, cause dano a outrem comete ato ilícito. Tem-se, dessa forma, a conduta caracterizada por uma ação comissiva ou omissiva, essa última ocorrendo quando havia um dever de praticar a ação e essa foi inexecutada.

Para Maria Helena Diniz:

"A ação, elemento constitutivo da responsabilidade, vem a ser o ato humano, comissivo ou omissivo, ilícito ou lícito, voluntário e objetivamente imputável do próprio agente ou de terceiro, ou o fato de animal ou coisa inanimada, que cause dano a outrem, gerando o dever de satisfazer os direitos do lesado." 14

Conduta, portanto, é o ato humano, a ação ou omissão, de que decorre o dano.

\subsection{Dano}

Dano é o prejuízo sofrido pela vítima decorrente da conduta praticada pelo ofensor, sendo essa comissiva ou omissiva.

Para Sérgio Cavalieri Filho, “o dano é, sem dúvida, o grande vilão da responsabilidade civil. Não haveria que se falar em indenização, nem em ressarcimento, se não houvesse o dano"15.

Continua ainda o Autor:

"Conceitua-se, então, o dano como sendo a subtração ou diminuição do bem jurídico, qualquer que seja a sua natureza, quer se trate de um bem patrimonial, quer se trate de um bem integrante da própria personalidade da vítima, como a sua honra, a sua imagem, a liberdade, etc. Em suma, dano é lesão de um bem jurídico, tanto patrimonial como moral, vindo daí a conhecida divisão do dano em patrimonial e moral" 16 .

Dessa monta, subtrai-se que o dano pode ser patrimonial ou extrapatrimonial. $\mathrm{O}$ dano patrimonial é aquele que acarreta à vítima prejuízo

\footnotetext{
${ }^{14}$ DINIZ, Maria Helena. Curso de Direito Civil Brasileiro - Responsabilidade Civil. 17 ed. São Paulo: Saraiva, 2003. VII p. 39.

${ }^{15}$ CAVALIERI FILHO, Sérgio. Op. Cit. p. 73.

${ }^{16}$ Idem.
} 
de cunho econômico, dividindo-se em danos emergentes e lucros cessantes. O dano emergente consiste na "efetiva e imediata diminuição no patrimônio da vítima, em razão do ato ilícito" ${ }^{17}$. Os lucros cessantes, por sua vez, se identificam como a expectativa de um ganho futuro, uma perda de um ganho que era esperável.

Já o dano extrapatrimonial importa em uma lesão à vítima sem valor econômico, mas que ainda assim deve ser compensado. Trata-se dos danos morais, danos estéticos, danos à honra, à imagem, à reputação, ao nome, entre outros.

\subsection{Nexo de Causalidade}

Por fim, para que haja o dever de indenizar não basta estarem presentes a conduta e o dano, mas deverá haver entre ambos uma relação de causalidade. É preciso que a conduta tenha dado causa ao dano.

Nas palavras de Sérgio Cavalieri Filho:

“... não basta, portanto, que o agente tenha praticado uma conduta ilícita; tampouco que a vítima tenha sofrido um dano. É preciso que esse dano tenha sido causado pela conduta ilícita do agente, que exista entre ambos uma necessária relação de causa e efeito. Em síntese, é necessário que o ato ilícito seja a causa do dano, que o prejuízo sofrido pela vítima seja resultado desse ato, sem o que a responsabilidade não ocorrerá a cargo do autor material do fato. Daí a relevância do nexo causal"18

Cabe ainda mencionar que o nexo de causalidade pode ser rompido diante de caso fortuito, força maior, fato exclusivo da vítima ou de terceiro, o que afasta a responsabilização do agente.

O estudo sobre o nexo de causalidade merece aqui ser aprofundado, diante da maior relevância para a responsabilidade civil pela perda de uma chance, conforme será demonstrado nos capítulos posteriores.

\footnotetext{
${ }^{17}$ CAVALIERI FILHO, Sérgio. Op. Cit. p. 74.

${ }^{18}$ Idem.
} 


\subsection{Teorias Aplicáveis ao Nexo de Causalidade}

O nexo de causalidade, embora aparente ser a simples ligação entre a conduta do agente ao dano, é, conforme Caio Mário da Silva Pereira:

"O mais delicado dos elementos da responsabilidade civil e o mais difícil de ser determinado. Aliás, sempre que um problema jurídico vai ter na indagação ou na pesquisa da causa, desponta a sua complexidade maior" ${ }^{\prime 19}$.

Quando o caso apresentado é simples, o nexo causal não enfrenta maiores problemas, sendo a relação de causalidade estabelecida de maneira direta entre o dano e o fato. $\mathrm{O}$ mesmo não ocorre naqueles casos de causalidade múltipla, quando há uma cadeia de condições e várias causas, ou concausas, concorrendo para o evento danoso. Aqui se deve precisar qual das causas de fato é a causa real do resultado.

Ou seja, o fato de a coincidência entre ação ou omissão e o dano não ser suficiente para configurar a causalidade faz com que se assegure que determinado ato ou omissão somente será considerado como causa se apresentar uma conditio sine qua non. ${ }^{20}$

São diversas as teorias que tentam solucionar o problema da causalidade múltipla, sendo apresentadas a seguir as três teorias com mais destaque na doutrina, levando em consideração o escopo do presente ensaio.

\subsubsection{Teoria da Equivalência das Condições}

A teoria da equivalência de condições é originária da doutrina alemã do século XIX e tem como percursor Von Buri. Pela teoria, todos os eventos que foram necessários para a ocorrência do dano são considerados como causas equivalentes. ${ }^{21}$ Não se indaga qual causa foi a mais ou a menos eficaz ou a mais ou a menos adequada, dado que todas são equivalentes.

\footnotetext{
${ }^{19}$ PEREIRA, Caio Mário da Silva. Responsabilidade Civil. Rio de Janeiro; Forense 2002 p. 76.

${ }^{20}$ SILVA, Rafael Peteffi da. Responsabilidade Civil Pela Perda de uma Chance: uma análise do direito comparado e brasileiro. $3^{\text {a }}$ ed. São Paulo: Atlas, 2013. p. 22.

${ }^{21}$ Idem.
} 
Sergio Cavalieri Filho explica que:

"Para saber se uma determinada condição é causa, elimina-se mentalmente essa condição, através de um processo hipotético. Se o resultado desaparecer, a condição é causa, mas, se persistir, não a será. Destarte, condição é todo antecedente que não pode ser eliminado mentalmente sem que venha a ausentar-se o efeito" 22 .

Dessa forma, todas as causas, antecedentes necessários do resultado, se equivalem. Essa teoria vem sendo criticada, dada a possibilidade de se atribuir ao dano uma infinita quantidade de causas, algumas delas demasiadamente remotas. Por tal razão, a doutrina e jurisprudência vêm deixando de adotar tal teoria.

\subsubsection{Teoria da Causalidade Adequada}

A teoria da causalidade adequada teve como percursores os alemães Von Kries e Rumelin ainda no final do século XIX e é de grande influência na doutrina e jurisprudência brasileira. Nessa teoria, a condição deve ser adequada e determinante na ocorrência do dano ${ }^{23}$.

Nessa teoria, a causa é:

“O antecedente não só o necessário mas também, o adequado à produção do resultado. Logo, se várias condições concorreram para determinado resultado, nem todas serão causas, mas somente aquela que for a mais adequada à produção do evento." 24

Segundo Aguiar Dias, o agente que deve reparar o dano não é aquele que teve a última chance de evitá-lo, mas aquele que teve a melhor e mais eficiente oportunidade de fazê-lo ${ }^{25}$. Denota-se a preponderância do caráter qualitativo da conditio sine qua non em detrimento do caráter puramente

\footnotetext{
${ }^{22}$ CAVALIERI FILHO, Sérgio. Op. Cit., p. 48.

${ }^{23}$ SILVA, Rafael Peteffi da. Op. Cit. p.23.

${ }^{24}$ CAVALIERI FILHO, Sérgio. Op. Cit. p. 49.

${ }^{25}$ AGUIAR DIAS, José de. Da Responsabilidade Civil. 12a Ed. Rio de Janeiro: Lumen Juris, 2012, p.695.
} 
temporal. Em outras palavras, o que importa não é a proximidade temporal que identifica a causa do dano, mas a proximidade lógica. ${ }^{26}$

\subsubsection{Teoria do Dano Direto e Imediato}

A teoria do dano direto e imediato estabelece que entre a conduta e o dano haja uma relação de causa e efeito direta e imediata.

Dessa feita, para a teoria aqui narrada o agente responde pelos danos que resultarem direta e proximamente de sua conduta. A causa jurídica, portanto, será apenas a condição que se vincula diretamente ao dano, sem interferência de outra condição sucessiva ${ }^{27}$.

Alguns doutrinadores acreditam que a teoria do dano direto e imediato é a teoria adotada por nosso ordenamento jurídico, estando essa positivada no art. 1060 do Código Civil de 1916, norma repetida no art. 403 do Código Civil de 2002.

O art. 403 do Código Civil afirma que:

"Ainda que a inexecução resulte do dolo do devedor, as perdas e danos só incluem os prejuízos efetivos e os lucros cessantes por efeito dela direto e imediato, sem prejuízo do disposta na lei processual."

No entanto, cumpre salientar que o referido dispositivo pertence ao título que trata do inadimplemento das obrigações no Código Civil de 2002, ou seja, possui relação expressa com a seara negocial. Não obstante, aqueles que são adeptos da teoria do dano direto e imediato consideram que o artigo em questão traça os fundamentos do nexo de causalidade para todo o sistema de responsabilidade civil, seja negocial ou extranegocial ${ }^{28}$.

Apesar da jurisprudência também já ter acolhido tal teoria, essa não é a posição majoritária. Caio Mário da Silva Pereira, Fernando Noronha, Sérgio Cavalieri Filho e Rafael Peteffi da Silva são apenas alguns

\footnotetext{
$\mathrm{E}^{26}$ SILVA, Rafael Peteffi da. Op. Cit. p.25.

${ }^{27}$ CAVALIERI FILHO, Sérgio. Op. Cit. p. 52.

${ }^{28}$ SILVA, Rafael Peteffi da. Op. Cit. p.26.
} 
doutrinadores que se filiam ao entendimento de que o nosso ordenamento jurídico adota a teoria da causalidade adequada e rechaçam a interpretação literal do dispositivo supramencionado.

Rafael Pettefi da Silva apresenta sua crítica à teoria do dano direto e imediato quando afirma que a interpretação gramatical da locução "direto e imediato" seria a negação da possibilidade de reparação de danos indiretos ou remotos como, por exemplo, o "dano por ricochete", adotado amplamente pela doutrina e jurisprudência ${ }^{29}$, e com previsão expressa na lei, no art. 948 , inciso II, do Código Civil de 2002. ${ }^{30}$

\subsection{Outras Considerações}

Traçadas tais considerações preliminares, imperioso notar ainda que, em alguns casos, se faz necessário uma flexibilização na aplicação dos elementos tradicionais da responsabilidade civil a fim de proteger a vítima, para que essa não se encontre injustamente sem reparação.

Nessa trilha, caminha a responsabilidade civil pela perda de uma chance, já que comporta uma forma especial de responsabilidade que, em certos casos, necessitará relativizar o nexo causal, além de outras especificidades que serão analisadas adiante.

\footnotetext{
${ }^{29}$ SILVA, Rafael Peteffi da. Op. Cit. p. 31

30 art. 948 CC: No caso de homicídio, a indenização consiste, sem excluir outras reparações:

I - no pagamento das despesas com o tratamento da vítima, seu funeral e o luto da família;

II - na prestação de alimentos às pessoas a quem o morto os devia, levando-se em conta a duração provável da vida da vítima. (grifo nosso)
} 


\section{Capítulo 2. Teoria da Perda de uma Chance}

\subsection{Origem e Evolução Doutrinária}

A problemática da responsabilidade pela perda de uma chance (perte d'une chance) teve sua origem na França na década de 60 do século XX. Importante caso na origem da teoria se deu em 1965, em uma decisão da Corte de Cassação Francesa. A teoria foi discutida no caso de responsabilidade de um médico que teria proferido diagnóstico equivocado, retirando, dessa forma, as chances de cura de seu paciente.

Tratava-se do caso de um menino de oito anos que havia sofrido um acidente e machucado o braço. Ele foi atendido por um médico que constatou uma fratura no braço e passou a tomar as medidas coerentes para curá-lo. Todavia, um tempo depois, o garoto continuava a sentir dores fortes, e foi constatado por outros médicos que ele apresentava um problema no cotovelo, tendo ficado com certas deficiências permanentes nos movimentos dos braços. Os peritos concluíram que o primeiro médico havia falhado em seu diagnóstico, causando sequelas na vítima. Entretanto, a Corte de Cassação francesa entendeu que a falha do médico não apresentava uma relação de causalidade absoluta com o dano final, afirmando que o erro no diagnóstico apenas havia subtraído algumas chances de cura. ${ }^{31}$

Em Responsabilidade Civil pela Perda de uma Chance: a álea e a técnica, Daniel Amaral Carnaúba cita outro caso emblemático do direito francês, que se deu em 1951. Trata-se do caso de um escritor francês chamado Sr. Jean-Gerard Chauffeteau, que recebeu proposta da Editora Flammarion para concorrer ao prêmio literário da revista Gazette des Lettres. O concurso previa como condição em seu edital uma tiragem mínima de mil exemplares da obra apresentada pelo candidato. Chauffeteau aceitou o convite da editora para participar no concurso e enviou seu manuscrito. Em uma primeira etapa eliminatória, sua obra foi uma das selecionadas. No

\footnotetext{
${ }^{31}$ SILVA, Rafael Peteffi da. Op. Cit. p.84.
} 
entanto, a Editora Flammarion declarou que não tinha a capacidade de imprimir o manuscrito de Chauffeteau no prazo e condições exigidas, e então o escritor se viu fora do concurso. Indignado, Chauffeteau procurou a Corte francesa visando à reparação por seus direitos violados ${ }^{32}$.

O tribunal francês viu-se com difícil caso em suas mãos, pois não havia como afirmar que Chauffeteau, caso continuasse no concurso, iria ganhá-lo. Todavia, não restavam dúvidas de que o ato culposo da editora havia acarretado grande prejuízo ao escritor. A solução encontrada pela Corte foi se valer de um método que já estava sendo aplicado na jurisprudência e condenou a editora a reparar as chances perdidas pela vítima. A obra de Chauffeteau já havia sido selecionada na primeira etapa do concurso, dentre outros muitos manuscritos, então a chance dele sair vitorioso do concurso era real. O tribunal condenou, portanto, a editora a pagar cem mil francos ao escritor. Note que o valor da reparação foi inferior ao prêmio prometido ao vencedor do concurso, de quinhentos mil francos.

Pode-se dizer que o tribunal francês para a solução do caso analisado aplicou a teoria da perda de uma chance. Conforme explica Daniel Carnaúba, houve um deslocamento do prejuízo, da perda do prêmio para a perda da chance de ganhar o prêmio. Além disso, outro elemento da responsabilidade civil foi deslocado: o nexo de causalidade.

\footnotetext{
"Para justificar a reparação, o tribunal afirma que há uma relação entre o ato culposo da editora e a perda da chance, e não mais entre aquele fato e a perda do prêmio." 33
}

Os tribunais franceses, em diversos casos, passaram a aplicar a técnica de reparação pela perda de chances. Casos clássicos, como o do advogado que perde o prazo para interpor recurso, privando o seu cliente de poder ter reformada a sentença e do candidato a concurso que, por culpa de outrem, é impedido de realizar as provas. A teoria foi aplicada também na França em

\footnotetext{
${ }^{32}$ CARNAÚBA, Daniel Amaral. Responsabilidade Civil pela Perda de uma Chance: a álea e a técnica. p.19.

${ }^{33}$ Ibid., p.20.
} 
casos de vítima de acidente que perde sua capacidade de trabalho, privando essa de evoluir e progredir na sua profissão ou no caso em que, em razão da morte de seu amado, a noiva perde a chance de casar. ${ }^{34}$

Em 1960, as vítimas de erro de tratamento médico na França passaram a ser reparadas pela perda de uma chance de sobrevida ou cura. Alguns anos depois, também passou-se a admitir a perda de uma chance na hipótese do dever de informar do médico, que se estendeu posteriormente a outras áreas.

Dessa forma, é possível depreender que o conceito de perda de uma chance foi "forjado pela jurisprudência francesa para exercer um papel preciso, a saber, pôr fim aos dilemas provocados pela incerteza nos casos de lesão a interesses sobre eventos aleatórios" ${ }^{35}$. Conforme aponta Carnaúba, trata-se de técnica decisória que favorece não apenas as vítimas, mas a própria coesão do sistema de reparação.

$\mathrm{Na}$ Itália, o tema da responsabilidade civil por perda de uma chance foi objeto de estudo em 1940, por Giovanni Pacchioni, professor da Universitá di Milano. ${ }^{36}$ Pacchioni também analisa o caso do advogado que perde o prazo do seu cliente, o caso do jóquei que deve montar cavalo de corrida, mas, por sua culpa, não consegue participar da corrida ou o caso do pintor que envia pelo correio seu quadro para participar de uma exposição, mas, por culpa do correio, o quadro não chega a tempo.

Para Pacchioni, em todos esses casos, as vítimas sofreram prejuízos. No entanto, se tais vítimas de fato possuem interesse jurídico para buscar reparação no judiciário, seria controverso, já que não há dano certo.

Dessa maneira, os atos culposos acima narrados fizeram com que as vítimas perdessem uma possibilidade de lucro, uma possibilidade aleatória, incerta. Não há um valor efetivo, certo e presente. Os casos citados acima, portanto, não passariam de meros aborrecimentos para Pacchioni, incapazes de gerar uma reparação civil, dada a ausência de um dano patrimonial certo ${ }^{37}$.

\footnotetext{
${ }^{34}$ Ibid., p.22.

${ }^{35}$ Ibid., p. 18

${ }^{36}$ SAVI, Sérgio. Responsabilidade Civil pela Perda de uma Chance. $3^{\text {a }}$ ed. São Paulo: Atlas, 2012. p. 7.

${ }^{37}$ SAVI, Sérgio. Op. Cit., p. 8.
} 
Nas palavras de Pacchioni, trata-se de "uma simples possibilidade, uma chance, tem sim valor social notável, mas não um valor de mercado". ${ }^{38}$

Contrário à posição de Pacchioni, foi Adriano De Cupis que, em 1966, publicou "Il Danno: Teoria Generale Della Responsabilitá Civile", em que reconheceu a possibilidade de indenização nos casos citados por Pacchioni. $\mathrm{O}$ autor afirma existir, nas hipóteses narradas acima, dano jurídico passível de indenização. De Cupis considerou o valor patrimonial da chance de vitória e foi além, enquadrando-a como espécie de dano emergente, o que eliminou as dúvidas acerca da certeza do dano. ${ }^{39}$

Outros autores enxergavam a chance de vitória como lucro cessante, o que dificultava a possibilidade de indenização. De Cupis considerou como dano emergente a perda da chance de vitória, e não da vitória em si. Com isso, afastou as objeções à incerteza do dano.

Quanto à quantificação do dano, o autor reconheceu que essa deveria ser feita de forma equitativa pelo juiz, mas não definiu qualquer método ou critério para tal. Ressaltou, no entanto, que o valor da chance da vitória deve ser sempre menor do que da vitória em si, o que reflete no valor da indenização. Além disso, nem todos os casos de perda de uma chance poderão ser indenizados ${ }^{40}$.

Em 1976, Mauricio Bocchiola, também professor da Universitá di Milano, publicou o artigo "Perdita di una chance e certeza del danno", aprofundando o tema ${ }^{41}$. A seguinte indagação é colocada pelo autor: "Mas, se não é possível determinar qual teria sido o resultado dos eventos, dos quais dependia a realização da chance, pode-se falar ainda, de dano certo e, portanto, ressarcível?" 42

A problemática do dano certo e o do enquadramento da chance da vitória como dano emergente ou lucro cessante também foi enfrentada por

\footnotetext{
${ }^{38}$ PACHIONNI, Giovanni. Direito Civile Italiano. apud SAVI, Sérgio. Op. Cit., p. 8.

${ }^{39}$ SAVI, Sérgio. Op. Cit., p. 11.

${ }^{40}$ DE CUPIS, Adriano. Il Danno: teoria generale dela responsabilite civile, 2. Ed, 2v. Milano: Giuffre, 1966 apud SAVI, Sérgio.Op cit. p. 10

${ }^{41}$ CARNAÚBA, Daniel Amaral. Op. Cit., p.14.

${ }^{42}$ BOCCHIOLA, Mauricio. Perddita di una chance e certeza del danno. In Rivista Trimestrale di Diritto e Procedura Civile. Anno XXX, p.55/101, 1976 apud Savi, Sérgio. Op. Cit., p.14.
} 
Bocchiola. $\mathrm{O}$ autor reconhece que existem características comuns entre a chance e o lucro cessante, principalmente no que tange a prova do dano. Em ambos os casos, a prova da certeza não poderá ser mais do que uma prova de verossimilhança. ${ }^{43}$ No entanto, em um ponto crucial se diferenciam: na certeza dos danos.

No lucro cessante, estamos tratando somente de uma perda de probabilidade favorável, probabilidade essa que representa a certeza. No lucro cessante, o autor não deve fazer prova do lucro em si, mas dos pressupostos e requisitos necessários para verificação desse lucro.

Já na perda de uma chance "o acontecimento do resultado útil é, por definição, de demonstração impossível”44.

Tendo em vista os seguintes apontamentos, Bocchiola chega à conclusão de que a perda de uma chance não pode ser indenizada como lucro cessante, mas como dano emergente. "Então, se a chance já fazia parte dos bens da vítima, a sua perda deve ser qualificada juridicamente como dano emergente". ${ }^{45}$

Bocchiola faz a ressalva, no entanto, de que não é qualquer perda de chance que será indenizável. Para o autor, a vítima somente será indenizada quando demonstrar que a probabilidade de conseguir a vantagem esperada for superior a $50 \%$. Somente assim se terá o dano certo, passível de indenização.

$\mathrm{Na}$ Argentina, se destacam os estudos de Juan Manuel Prevot acerca da responsabilidade civil pela perda de uma chance na seara médica, que classifica a teoria da perda de uma chance como "um eficiente instrumento jurídico enquanto tende a repartir proporcionalmente o prejuízo entre a vítima e o agente". ${ }^{46}$ Dessa forma, a teoria, segundo o autor, não permite que

\footnotetext{
${ }^{43}$ BOCCHIOLA, Mauricio.Op. Cit. p. 15 .

${ }^{44}$ Ibid., p. 17.

${ }^{45}$ Ibid., p. 22.

46 PREVOT, Juan Manuel. Responsabilidade Civil de los Médicos. Buenos Aires: Abeledo Perrot, 2008. p 87 apud Martins de Casto, Alexandre; Casas Maia, Maurilio. A Responsabilidade Civil pela Perda de uma Chance de Cura ou Sobrevivência na Atividade Médica: Entre a Doutrina e a visão do Superior Tribunal de Justiça. In Revista de Direito do Consumidor. Ano 23. Vol. 95. Coordenação Claudia Lima Marques. p. 295.
} 
a dúvida quanto à causalidade acarrete reparação excessiva ao agente ou deixe a vítima desamparada, sem reparação, pois imprime "solução distribuidora de ônus proporcionais entre paciente e médico, por meio de uma indenização parcial em relação ao dano final do enfermo". ${ }^{47}$

As questões aqui suscitadas que decorrem do estudo da reponsabilidade civil pela perda de uma chance serão adiante aprofundadas.

\title{
2.2. A Perda de uma Chance e suas Modalidades
}

A problemática central que se apresenta no tema em análise se constrói diante das situações em que por conta da conduta de outrem uma chance é retirada, desaparecendo a oportunidade da vítima de vir a obter no futuro uma vantagem ou benefício. Como bem denota Sérgio Cavalieri Filho, deve-se entender por chance "a probabilidade de se obter um lucro ou de se evitar uma perda" ${ }^{48}$. No entanto, há aqueles que entendem que os pressupostos essenciais para a reparação não estariam presentes, por não se poder afirmar com certeza que a conduta do agente foi causadora de dano.

Fernando Noronha assim observa acerca da caracterização da perda da chance:

\begin{abstract}
"Quando se fala em chance, estamos perante situações em que está em curso um processo que propicia a uma pessoa a oportunidade de vir a obter no futuro algo benéfico. Quando se fala em perda de chances, para efeitos de responsabilidade civil, é porque esse processo foi interrompido por um determinado fato antijurídico e, por isso, a oportunidade ficou irremediavelmente destruída. ${ }^{49}$,
\end{abstract}

Posta assim a questão, com o intuito de enfrentar o tema com maior clareza, resolveu-se apresentar a classificação teórica que divide a perda de uma chance em duas categorias: (i) a perda de uma chance de se obter uma vantagem futura e (ii) a perda de uma chance de ter evitado um prejuízo ${ }^{50}$.

\footnotetext{
${ }^{47}$ MARTINS DE CASTRO, Alexandre; CASAS MAIA, Maurilio. A Responsabilidade Civil pela Perda de uma Chance de Cura ou Sobrevivência na Atividade Médica: Entre a Doutrina e a visão do Superior Tribunal de Justiça p. 295.

${ }^{48}$ CAVALIERI FILHO, Sérgio. Op. Cit. p.77.

${ }^{49}$ NORONHA, Fernando. Op. Cit. p. 665.

${ }^{50}$ Ibid., p. 676.
} 
Também conhecida como a perda de uma chance clássica, a perda de uma chance de se obter uma vantagem futura engloba os casos já narrados do advogado que perde o prazo para recorrer e do participante que deixou de prestar concurso por culpa de outrem.

Nesses casos, o processo aleatório foi interrompido antes de chegar ao seu fim, e a vítima teve todas as suas chances esgotadas. Desse modo, não há como saber o resultado do processo aleatório caso transcorresse até o seu término. Apenas resta uma probabilidade do resultado que se esperava ou "uma suposição legítima do futuro" 51 .

Por seu turno, nos casos, por exemplo, de perda de uma chance de cura ou de sobreviver envolvendo paciente que não foi curado devido à conduta culposa do médico, o processo aleatório chega ao seu fim, e se sabe com certeza qual o resultado. As chances perdidas, portanto, são analisadas no passado. Trata-se da perda de uma chance de ter evitado um prejuízo. A única dúvida que paira é em relação à causa do dano: se esse ocorreu por conta de falha médica ou não, ou seja, se há uma relação de causalidade entre a conduta médica e o dano final ${ }^{52}$.

Nessa modalidade, em que o processo aleatório transcorre até o fim, muitos são os exemplos utilizados na seara médica. Isso porque:

\footnotetext{
"A álea clínica e a individualidade de cada organismo humano não permite que a medicina oferte exatidão matemática quanto aos resultados aguardados para os pacientes. Por isso, a relação de causalidade entre o dano suportado pelo enfermo e a conduta médica nem sempre é passível de prova contundente e clara, embora seja altamente possível. ${ }^{53}$
}

Fernando Noronha propõe classificação própria para as modalidades de perda de uma chance, sendo estas: "frustração da chance de obter uma vantagem futura" e "frustração da chance de evitar um dano efetivamente acontecido". Essa última categoria comporta ainda uma subdivisão entre a

\footnotetext{
${ }^{51}$ SILVA, Rafael Peteffi da. Op. Cit.. p. 86.

${ }^{52}$ Idem.

${ }^{53}$ MARTINS DE CASTRO Alexandre; CASAS MAIA, Maurilio. Op. Cit. p. 296.
} 
"perda de uma chance de evitar que outrem sofresse um prejuízo" e a "perda de uma chance por falta de informação" 54 .

A modalidade proposta por Noronha da "perda da chance de obter uma vantagem futura" estaria vinculada aos "casos clássicos" da doutrina francesa. Já na categoria "frustração de chances de evitar um dano" estariam os casos em que o processo aleatório vai até o seu final.

Assim, as modalidades apresentadas por Noronha também utilizam como critério o fato do processo aleatório ter transcorrido até o seu final ou não. No seu dizer sempre preciso, o autor assim preconiza:

\begin{abstract}
"Enquanto na perda de chance clássica o fato antijurídico interrompeu um processo em curso e o possível dano resulta desta interrupção, no caso da perda de chance de evitar um prejuízo o dano surge exatamente porque o processo em curso não foi interrompido, quando poderia tê-lo sido. Se o processo tivesse sido interrompido, haveria a possibilidade de o dano não se verificar, mas sem se poder agora se realmente isto teria acontecido" ${ }^{\circ 5}$.
\end{abstract}

Tal diferenciação teórica também é feita pela doutrina francesa, entre a aplicação clássica da perda de uma chance, que são os "casos clássicos", tais como os primeiros descritos acima, em que se reconhece o dano específico, e da perda de uma chance em matéria médica ${ }^{56}$.

No dizer sempre expressivo de René Savatier:

"O escopo dessa doutrina é estabelecer a diferença e denunciar a confusão feita entre a reparação retrospectiva da perda de uma possibilidade pretérita e incerta de causar dano e a reparação de uma perda para o futuro" 57 .

Savatier pondera ainda que, nos "casos clássicos", a chance pode ser isolada como "uma propriedade anterior da vítima, que está incluída no seu patrimônio e se encontra totalmente independente do dano final"58. A conduta do ofensor impossibilita o processo aleatório e retira a álea própria

\footnotetext{
${ }^{54}$ NORONHA, Fernando. Op. Cit. p.668.

${ }^{55}$ Ibid., p. 676.

56 SILVA, Rafael Peteffi da. Op. Cit. p.84.

${ }^{57}$ SAVATIER, Rene. 1970 p.123 apud Silva, Rafael Peteffi da. p. 84

${ }^{58}$ SAVATIER, Rene. 1966, e DOSNER DOLIVET, Annick 1984 p.306 apud Silva, Rafael Peteffi da. p. 84.
} 
da vantagem esperada. Portanto, resta absoluta a relação causal entre o fato danoso e a perda das chances, caracterizando essas chances como um dano específico distinto do dano final ${ }^{59}$.

Já, nos casos médicos, o processo que poderia ter sido aleatório já não o é, pois se sabe com certeza o seu resultado, a morte ou a invalidez do paciente.

Cite-se, à guisa de exemplo, um caso da Corte de Apelação de Paris, julgado em março de 1966: uma mulher que, após parir, faleceu em razão de hemorragia. A Corte entendeu que o médico, nesse caso, foi negligente, pois deixou a paciente sem assistência após realizar o parto. A Corte, no entanto, concluiu não se tratar de condenação integral já que os peritos afirmaram que, mesmo adotando os procedimentos corretos, em torno de $20 \%$ dos pacientes nesse estado falecem. Assim, condenou-se o médico pela perda de $80 \%$ das chances de cura. ${ }^{60}$

René Savatier critica essa decisão, afirmando que julgamentos assim estão em desacordo com os princípios de direito comum sobre a causalidade, divergindo dos "casos clássicos" de responsabilidade pela perda de uma chance.

A doutrina francesa majoritária está de acordo com Savatier, que assevera inclusive que a utilização da teoria da perda de uma chance em matéria médica é "o paraíso do juiz indeciso", devendo ser rechaçada, pois representa um desvirtuamento da causalidade e um risco ao sistema ${ }^{61}$.

Não é mansa e pacífica a questão, todavia, tendo Georges Dury, dentre outros, criticado a classificação exposta, arguindo que não há uma diferenciação nítida entre as hipóteses, dado que os casos nos quais o processo aleatório chega ao fim não se limitam aos casos da seara médica ${ }^{62}$.

Como exemplo, o doutrinador cita caso hipotético de estudante que visa a fazer prova de vestibular, mas sofre acidente por culpa de outrem.

\footnotetext{
59 JOURDAN, Patrice, 1992, p.109 apud Silva, Rafael Peteffi da. p. 88.

${ }^{60}$ SILVA, Rafael Peteffi da. Op. Cit. p.84.

${ }^{61}$ SAVATIER, Rene. 1966, apud Silva, Rafael Peteffi da. p.89.

62 DURRY, Georges. 1967, p.181, em reposta ao comentário de Savatier, JCP, 1966 apud Silva, Rafael Peteffi da p.98.
} 
Mesmo estando extremamente debilitado, o estudante vai realizar o seu exame, com as suas chances reduzidas. Caso ele não logre êxito, o processo aleatório chega ao seu fim. Aqui também se estarão se analisando as chances perdidas no passado, sob uma análise pretérita, já se sabendo o resultado final.

Outro não é o entendimento de Rafael Peteffi da Silva, que, após análise sobre a doutrina francesa, preceitua que a divisão entre os "casos clássicos" e os casos da seara médica não poderiam representar as modalidades de perda de uma chance. Sérgio Savi, em Responsabilidade Civil pela Perda de uma Chance, separa as modalidades em: o processo aleatório que é interrompido, com a perda definitiva da vantagem esperada e o processo aleatório que chega ao final ${ }^{63}$.

\subsection{A Perda de uma Chance como um Dano Autônomo}

Durante muito tempo, o dano representado pela perda de uma chance não era tutelado pelo Direito, deixando as vítimas sem qualquer reparação. Tal entendimento se dava por conta do tradicional princípio da responsabilidade civil que prescreve que os danos, para serem passíveis de indenização, devem ser certos e não hipotéticos ou eventuais.

A doutrina e jurisprudência, então, resolveram voltar os olhos para tal injustiça que, com a ajuda do desenvolvimento da ciência das probabilidades e estatística, tornaram possível uma nova espécie de danos indenizáveis: as chances perdidas ${ }^{64}$.

O que será indenizado é a chance que foi perdida de se alcançar um resultado, devido à conduta danosa de outrem. Nos casos em que o processo aleatório não chega ao seu fim, pode-se identificar um dano autônomo, que é a chance perdida.

Fernando Noronha assim dispõe:

\footnotetext{
${ }^{63}$ SAVI, Sergio. Responsabilidade Civil pela Perda de uma Chance. p. 46.

${ }^{64}$ SILVA, Rafael Peteffi da Op. Cit. p.116.
} 
"Todavia, apesar de ser aleatória a possibilidade de obter o benefício em expectativa, nestes casos existe um dano real, que é constituído pela própria chance perdida, isto é, pela oportunidade, que se dissipou, de obter no futuro a vantagem, ou de evitar o prejuízo que veio a acontecer"65.

No caso do advogado que perde o prazo do recurso ou do participante que deixa de prestar concurso, a vantagem final esperada pela vítima integra o patrimônio dessa.

Dessa feita, a chance perdida também possui natureza patrimonial, assim como a vantagem final que era esperada. Em ambas as modalidades de perda de uma chance apresentadas, tendo o processo aleatório transcorrido até o fim ou não, o objeto da reparação não incide sobre a vantagem final, mas sobre a possibilidade de que a vantagem fosse auferida ("casos clássicos") ou na possibilidade de que o dano final não fosse experimentado pela vítima.

Cai a lanço notar que não é qualquer chance perdida que será indenizada. Para indenização das chances perdidas, enquanto dano autônomo, é necessária a presença do dano e do nexo causal entre a conduta do agente e o evento danoso. Ressalte-se que o nexo de causalidade não se configura entre a conduta do ofensor e a perda da vantagem final, mas sim entre a conduta do ofensor e a perda da oportunidade de obter a vantagem final.

Em virtude dessas considerações, Rafael Peteffi da Silva alerta que não se pode confundir as hipóteses de responsabilidade civil pela perda de uma chance com os casos de simples criação de riscos. O ponto frágil aqui reside na vulgarização dos termos, dado que se pode dizer que as chances perdidas pela vítima fazem com que se aumente o risco de perder a vantagem esperada ${ }^{66}$.

Rafael Peteffi da Silva, acerca do tema, assim avalia:

\footnotetext{
${ }^{65}$ NORONHA, Fernando. Op. Cit. p.667.

${ }^{66}$ SILVA, Rafael Peteffi da. Op. Cit. p.116.
} 
"O ponto nefrálgico para a diferenciação da perda de uma chance da simples criação de um risco é a perda definitiva da vantagem esperada pela vítima, ou seja, a existência do dano final. De fato, em todos os casos de perda de uma chance, a vítima encontra-se em um processo aleatório que, ao final, pode gerar uma vantagem. Entretanto, no momento em que as demandas envolvendo a perda de uma chance são apreciadas, o processo chegou ao seu final, reservando um resultado negativo para a vítima."

"Mesmo nos casos clássicos de perda de uma chance, nos quais o processo aleatório não chega ao seu final, mas é definitivamente interrompido pela conduta do réu, observa-se a perda da vantagem esperada. Assim, por exemplo, o litigante perde definitivamente a causa judicial quando o advogado interpõe um recurso intempestivo. Nesta hipótese, a vantagem esperada pela vítima era a procedência da demanda, a qual restou totalmente prejudicada." ${ }^{\circ 7}$

Continua ainda o Doutrinador:

"Nos casos de simples aumento de riscos, a vítima também se encontra em um processo aleatório que visa alcançar uma vantagem ou evitar um dano. Entretanto, a vítima ainda não sofreu o prejuízo derradeiro, tampouco perdeu a vantagem esperada de forma definitiva, mas, devido à conduta do réu, aumentaram os riscos de ocorrência de uma situação negativa. É impossível saber se em momento futuro a perda definitiva da vantagem esperada pela vítima será efetivamente observada" 68 .

Para exemplificar ao leitor o que se refere por caso de simples aumento de riscos, Peteffi da Silva comenta o caso clássico de pessoa que é exposta a elemento tóxico e seu risco de contrair doença sofre aumento substancial, embora goze esta de saúde perfeita. Não se sabe se a vítima contrairá ou não a doença, já que essa pode ficar em estado de latência por anos ou pode nunca ocorrer. Dessa forma, a vantagem esperada pela vítima, a manutenção da saúde perfeita, ainda pode ser alcançada.

Destarte, depreende-se que conferir a reparação antes da certeza do dano se torna muito difícil. Nos casos de responsabilidade pela perda de uma chance, isso não ocorre, já que o dano se manifesta de forma definitiva: a perda da vantagem esperada. Verifica-se, portanto, o dano da chance perdida, sendo esse independente e autônomo.

\footnotetext{
${ }^{67}$ Ibid., p. 117.

${ }^{68}$ Idem.
} 


\subsubsection{A diferença entre dano da chance perdida e os lucros cessantes}

Conforme já abordado em seção anterior, a doutrina e jurisprudência divergem quanto ao enquadramento da perda da chance de se alcançar a vantagem final esperada como dano emergente ou lucro cessante.

Tal dicotomia, entre danos emergentes e lucros cessantes, foi expressamente abarcada pelo Código Civil de 2002, em seu art. 40269, dispondo que as perdas e danos devidas ao credor abrangem o que ele efetivamente perdeu - os danos emergentes - e o que razoavelmente deixou de lucrar - os lucros cessantes.

O critério distintivo desses conceitos é o impacto da lesão ao status quo ante. $\mathrm{O}$ dano emergente ocorre quando o acidente provoca a depreciação do estado em que se encontrava a vítima. Já os lucros cessantes não representam um decréscimo, mas o “óbice à melhora da situação do lesionado"70, sem uma depreciação do status quo ante. Os lucros cessantes abarcam os valores que a vítima deixou de ganhar em razão do incidente, valores esses que não pertenciam ao seu patrimônio até o momento ${ }^{71}$.

Segundo as regras da responsabilidade civil, para se avaliar o dano toma-se como base a diferença entre a situação real, na qual se encontra a vítima, e a situação contrafatual na qual se encontraria sem a conduta do ofensor.

Daniel Carnaúba pondera nesse ponto que,

"A técnica de reparação de chances subverte esse princípio, propondo-se a recolocar a vítima não mais na situação em que ela estaria sem o evento danoso, mas na situação em que ela se encontrava até o evento em questão".

\footnotetext{
${ }^{69}$ Art. 402 CC: Salvo as exceções expressamente previstas em lei, as perdas e danos devidas ao credor abrangem, além do que ele efetivamente perdeu, o que razoavelmente deixou de lucrar.

${ }^{70}$ CARNAÚBA, Daniel Amaral. Op. Cit., p.166

${ }^{71}$ CARNAÚBA, Daniel Amaral. Op. Cit., p.167.
} 
Assim, a chance que a vítima possuía antes do ato do ofensor desaparece, e deve ser reparada.

A chance, portanto, deve ser tratada como um bem, material ou imaterial, pertencente à vítima, bem esse inserido em seu patrimônio anterior ao evento danoso. Por essa razão, conclui-se que a chance perdida deve ser tratada como dano emergente.

É esse o raciocínio de Mauricio Bocchiola, em "Perdita di una chance e certeza del danno", que afirma que a perda de uma chance não pode ser indenizada como lucro cessante, mas como dano emergente. "Então, se a chance já fazia parte dos bens da vítima, a sua perda deve ser qualificada juridicamente como dano emergente". ${ }^{72}$

\subsubsection{Dano da Chance Patrimonial Perdida e o Dano Moral}

Outra importante classificação na seara da Responsabilidade Civil é aquela que divide os danos entre patrimoniais e morais. Necessário é lembrar que, em síntese, dano patrimonial constitui em uma lesão ao interesse pecuniário da vítima e o dano moral na lesão a bem insuscetível de mensuração em pecúnia, decorrentes na maioria das vezes dos direitos da personalidade. No dano patrimonial, o bem jurídico atingido é o patrimônio, enquanto, no dano moral, o bem prejudicado é extrapatrimonial.

Diante da indagação sobre em qual categoria se enquadraria a chance perdida, tem-se que essa, em realidade, não pertence necessariamente a uma ou outra categoria. A perda de uma chance pode representar um dano patrimonial ou moral à vítima, ou ainda acarretar danos patrimoniais e morais. Tudo vai depender do caso concreto.

A título de exemplo, Daniel Carnaúba cita algumas hipóteses em Responsabilidade Civil pela Perda de uma Chance: a álea e a técnica. A primeira das hipóteses é a do advogado que perde o prazo para interpor recurso contra sentença que condenou seu cliente ao pagamento de uma

${ }^{72}$ BOCCHIOLA, Maurizio. Perddita di una chance. p.97 apud Savi, Sérgio. p.22. 
dívida, causando a esse um dano patrimonial. O interesse lesado é patrimonial, e a indenização da vítima será auferida tomando-se como base as chances de sucesso do recurso caso esse tivesse sido interposto ${ }^{73}$.

Por sua vez, a segunda hipótese trata do cliente que contrata advogado para entrar com ação de reconhecimento de paternidade, sem intuitos pecuniários, e este comete um erro, prejudicando o cliente. Aqui o dano sofrido pelo cliente tem natureza extrapatrimonial, constituindo a chance perdida em dano moral, que deverá ser compensado ${ }^{74}$.

Por fim, na terceira e última hipótese, o Autor menciona caso do paciente que, por conta de tratamento inadequado, perde chances de cura, restando inválido. Nesse caso, a vítima sofre lesões tanto aos seus interesses patrimoniais, como a perda da capacidade laboral, quanto aos seus interesses extrapatrimoniais, tendo sido lesada a sua integridade física. Ambos os danos devem ser indenizados, a partir das perspectivas de cura oferecidas pelo tratamento negligenciado ${ }^{75}$.

Outro não é o entendimento do Superior Tribunal de Justiça que já consolidou que "a perda da chance se aplica tanto aos danos materiais quanto aos danos morais" $" 76$.

Cumpre observar ainda que, em alguns casos de perda de chance, a vítima pode sofrer, além dos danos decorrentes da chance perdida, outros danos de cunho moral. A perda da oportunidade pode ofender também outros interesses da vítima, tais como sua honra, dignidade, abalo psicológico, entre outros, configurando um dano moral autônomo, que deve ser reparado além da chance perdida ${ }^{77}$.

Daniel Carnaúba exemplifica com o caso do esportista impedido de participar de competição decisiva em sua carreira. Lembre-se aqui do lastimável ocorrido com o maratonista Vanderlei Cordeiro de Lima na Olimpíada de Atenas de 2004. O atleta ocupava a primeira posição na corrida

\footnotetext{
${ }^{73}$ CARNAÚBA, Daniel Amaral. Op. Cit., p.170.

${ }^{74}$ Ibid., p. 171.

${ }^{75}$ Idem.

${ }^{76}$ STJ, REsp 1.079.185/MG, Rel. Min. Nancy Andrighi j.11.11.2008.

${ }^{77}$ CARNAÚBA, Daniel Amaral. Op. Cit., p. 172.
} 
quando um espectador invadiu a pista e o retirou nos momentos finais da competição. Não há dúvidas de que tal incidente provocou grandes frustrações no atleta, que vão além da sua chance perdida de vitória. Aqui a vítima teve a sua oportunidade de vitória prejudicada, sob a ótica da reparação de chances. A indenização ocorreria de forma proporcional à probabilidade de vitória do atleta e aos danos materiais e morais que decorrem de uma conquista dessa estirpe. No entanto, não é apenas a simples vitória na corrida que está em jogo, pois dada a grandiosidade do evento, esse representa algo muito estimado para o atleta em sua carreira. Logo, caberia também reparação do dano moral, além da chance perdida indenizada ${ }^{78}$.

\subsubsection{A Perda de uma Chance embasada na Teoria da Causalidade Parcial}

Outra questão relevante enfrentada pela doutrina envolve a causalidade parcial. Conforme já visto neste ensaio, em todas as teorias do nexo causal: a teoria da equivalência das condições, teoria da causalidade adequada, teoria do dano direto e imediato, a conditio sine qua non ou ainda condição necessária era requisito para formar o nexo causal entre a conduta do agente e o dano sofrido pela vítima. E, em regra, essa prova deve ser efetuada pela vítima quando ingressa com a demanda visando à reparação.

Entretanto, em alguns casos, conforme preceitua Vasco Della Giustina, devido às novas realidades sociais, tecnológicas e econômicas, o nexo de causalidade precisa ser "flexibilizado", quando, por exemplo, ocorre o desencadeamento de diversas causas ou o dano se dá de forma muito rápida e sem testemunhas ou, ainda, quando se estiver lidando com casos em que o ofensor exerça atividade poluente ${ }^{79}$.

$\mathrm{Na}$ França, são vários os exemplos de utilização de presunções, uma das formas de relativizar o princípio de que incumbe ao autor provar o nexo

\footnotetext{
${ }^{78}$ Idem.

${ }^{79}$ DELLA GIUSTINA, Vasco, 1991 p. 54 apud Silva, Rafael Pettefi da. p. 47.
} 
causal entre conduta do agente e o dano. São os casos de acidentes nucleares, acidentes de trabalho, acidentes de trânsito, responsabilidade pelo guardião da coisa, responsabilidade dos pais pelos filhos e inadimplemento de uma obrigação de resultado ${ }^{80}$.

Geneviève Viney pondera que existem ainda outros casos nos quais há uma relação de causalidade bastante provável, mas não totalmente certa, sendo esses quando “...o processo causal escapa a uma observação mais direta ou quando a multiplicidade de causas gera grande complexidade" $"$.

Quanto às hipóteses de responsabilidade civil pela perda de uma chance em que o processo aleatório transcorre até o seu fim e não é interrompido, como sói acontecer na seara médica, a flexibilização do nexo causal se dá através da aplicação da teoria da causalidade parcial.

Miguel Kfouri, que realizou aprofundado estudo sobre a responsabilidade civil pela perda de uma chance na seara médica, observa que: "Como visto, a perda de uma chance, no domínio médico, atinge a causalidade, ao passo que nas demais áreas da responsabilidade civil referese ao prejuízo." 82

$\mathrm{O}$ autor, no entanto, atenta para o fato de que a teoria "deve ser interpretada com a máxima cautela" 83 . Trata-se de uma teoria facilitadora do acesso à indenização, em consonância com o novo paradigma civilista em que vigora o princípio da solidariedade.

\footnotetext{
"Desse modo, de fato, há que se impor cautela aos magistrados por ocasião da aplicação da teoria da perda de uma chance na área médica, na medida em que a sua utilização não pode significar mera caridade com o direito alheio" ${ }^{84}$.
}

\footnotetext{
${ }^{80}$ VINNEY Genieve ; JOURDAN, Patrice 1998, p.184 et seq Rafael Pettefi da. p. 47.

${ }^{81}$ VINNEY, Genevieve, JOURDAN, Patrice, 1998, p.191 e Della Giustina, Vasco, 1991 p. 55, 58 apud Rafael Pettefi da. p. 48.

${ }^{82}$ KFOURI NETO, Miguel. Culpa Médica e Ônus da Prova: Presunções, perde de uma Chance, cargas probatórias dinâmicas, inversão do ônus probatório e consentimento informado: responsabilidade civil em pediatria, reponsabilidade civil em gineco-obstetrícia. São Paulo: Revista dos Tribunais, 2002. p.11.

${ }^{83}$ KFOURI NETO, Miguel. Culpa Médica e Ônus da Prova: Presunções, perde de uma Chance, cargas probatórias dinâmicas, inversão do ônus probatório e consentimento informado: responsabilidade civil em pediatria, reponsabilidade civil em gineco- obstetrícia. p.74/75.

${ }^{84}$ MARTINS DE CASTRO, Alexandre; CASAS MAIA, Maurilio. Op. Cit. p.297.
} 
Jacques Boré e John Makdisi defendem a causalidade parcial como solução para todos os casos de perda de uma chance. Se o ato do ofensor não pode ser considerado como a conditio sine qua non, a causalidade parcial pode ser utilizada para reparação de um prejuízo "parcial e relativo, consubstanciada na perda das chances". John Makdisi afirma que a reparação deve ser quantificada de acordo com a probabilidade de causalidade provada $^{85}$.

Dessa forma, se ficar comprovado que existem oitenta por cento $(80 \%)$ de probabilidade de que a conduta do réu tenha causado o dano sofrido pela vítima, o dano será quantificado em oitenta por cento (80\%) do prejuízo total. Já, se apenas uma probabilidade causal de quarenta por cento (40\%) for comprovada, será essa a proporção na qual será calculada a indenização ${ }^{86}$.

Portanto, em vez de considerar as chances perdidas como um dano autônomo, concebem-se as chances perdidas como um meio de quantificar o liame causal entre a ação do agente e o dano final (perda da vantagem esperada) $)^{87}$.

John Makdisi entende que a utilização do padrão "tudo ou nada", ou seja, a condenação do dano se convencido o juiz de que o ofensor o causou ou a não condenação quando não há provas suficientes para apontar o réu como o causador, "gera subcompensações ou ultracompensações". Mas, quando se aplica a teoria da causalidade parcial, o réu responderá na medida em que tiver causado o dano, conforme os estudos das estatísticas demonstrarem no caso concreto ${ }^{88}$.

Jacques Boré obtempera ainda que, quando o juiz não se utiliza das estatísticas no caso concreto, acaba sendo forçado a fazer presunções para comprovar o nexo causal, saltando "do conhecido ao desconhecido" 89 . Essa presunção "está repleta de álea, é mais arbitrária e mais fraca como

\footnotetext{
${ }^{85}$ SILVA, Rafael Peteffi da. Op. Cit. p. 50.

${ }^{86}$ MAKDISI, John, 1989, p. 1065 apud Silva, Rafael Peteffi da. p. 50.

${ }^{87}$ SILVA, Rafael Peteffi da. Op. Cit. p. 50.

${ }^{88}$ MAKDISI, John, 1989, p. 1092-1093. apud Silva, Rafael Peteffi da. p. 52.

${ }^{89}$ BORÉ, Jacques, 1974. apud Peteffi da Silva p. 53.
} 
fundamento do livre convencimento do magistrado, que teria um conteúdo científico mais apreciável se baseado nas estatísticas" ${ }^{\prime 90}$.

$\mathrm{Na}$ França, a doutrina majoritária não aceita a aplicação da responsabilidade civil pela perda de uma chance em que o processo aleatório tenha transcorrido até o fim, como na seara médica. René Savatier e Jean Penneau alertam sobre o "perigo sistemático" concebido pelas chances perdidas após a conclusão do processo aleatório ${ }^{91}$.

Com a aplicação da teoria da perda de uma chance nesses casos, segundo esses autores, não mais seriam observadas as condenações integrais dos danos, pois o juiz deixaria de buscar quem realmente causou o dano para saber qual a porcentagem de chances que o réu retirou da vítima.

A regra do "tudo ou nada" é, por iso, aqui defendida, sendo a aplicação da perda de chances, quando o processo aleatório chega ao seu fim, uma ameaça a tal regra, pois a dúvida acerca do nexo de causalidade já não mais geraria sentenças de improcedência, mas passaria a gerar sempre uma reparação parcial do dano "medida pelo grau de incerteza que cerca o livre convencimento do juiz"92. É por isso que René Savatier declara que a perda de uma chance aplicada à seara médica seria o "paraíso do juiz indeciso"93.

Jacques Boré, portanto, é um dos poucos na doutrina francesa que sustenta a aplicação da causalidade parcial. $\mathrm{O}$ restante parece defender, de forma enérgica, a regra do "tudo ou nada": caso o nexo de causalidade não seja comprovado, não cabe reparação à vítima; caso contrário, aplica-se a presunção de causalidade, tentando alcançar a reparação do dano final.

Geneviève Viney não se mostra adepto da adoção da teoria da perda de uma chance na seara médica, mas, conforme já mencionado acima, acredita que, nesses casos, deve-se adotar uma presunção de causalidade em favor da vítima, facilitando a reparação do dano ${ }^{94}$.

\footnotetext{
${ }^{90}$ SILVA, Rafael Peteffi da Op. Cit. p. 60.

${ }^{91}$ Ibid., p.246.

${ }^{92}$ PENNEAU, Jean. D. 1986, p. 393; SAVATIER, Rene JCP, 1966 II. 14756 e RABUT , A.1970 apud Silva, Rafael Peteffi da. p. 246.

${ }_{93}^{93}$ SAVATIER, Rene. JCP, 1966, II 14756. apud Silva, Rafael Peteffi da p. 246.

${ }^{94}$ VINNEY, Genevieve. Jourdain, Patrice 1998, p.204. apud Silva, Rafael Peteffi da p. 247.
} 
Georges Durry e Yves Chartier vão contra a posição majoritária francesa, sendo favoráveis à aplicação da responsabilidade civil pela perda de uma chance na seara médica, através da caracterização das chances perdidas como uma espécie de dano específico. Não é feita aqui a diferenciação entre os casos nos quais o processo aleatório transcorreu até o fim e os "casos clássicos"

Nessa linha, o norte-americano Joseph King Jr sustenta que as chances perdidas pela vítima, mesmo na seara médica, representam um dano autônomo e "perfeitamente reparável", sendo dispensável a utilização alternativa do nexo de causalidade ${ }^{96}$. $\mathrm{O}$ autor vislumbra que os tribunais têm falhado em identificar a chance perdida como um dano reparável.

\footnotetext{
"Desse modo, algo que é visceralmente probabilístico passa a ser encarado como certeza ou como impossibilidade absoluta. É exatamente devido a esse erro de abordagem que os tribunais, quando se deparam com a evidente injustiça advinda da total improcedência de uma espécie típica de responsabilidade pela perda de uma chance, acabam por tentar modificar o padrão "tudo ou nada" da causalidade, ao invés de reconhecer que a perda da chance, por si só, representa um dano reparável." 97
}

Importante destacar o argumento trazido por Peteffi da Silva em defesa da adoção da teoria da perda de uma chance na seara médica: o caráter pedagógico (deterrence) que essa traz consigo, caráter esse que deve ser exercido pela responsabilidade civil. "O dever de indenizar o dano causado deve desmotivar o agente, bem como toda a sociedade, de cometer novamente o mesmo ato ofensivo" $"$.

A não aplicação da teoria da perda de uma chance na seara médica permitiria que tais profissionais não agissem com o zelo e cautela necessários com os pacientes que possuem poucas chances de vida. Explica o Autor sobre tal afirmativa:

\footnotetext{
95 SILVA, Rafael Peteffi da. Op. Cit. p. 247.

96 KING JR., Joseph H. Causation, valuation and chance in personal injury torts involving preexisting conditions and future consequences. Yale Law Journal, v. 90, 1981, p. 1353, apud Silva, Rafael Peteffi da. p. 77.

${ }^{97}$ KING JR, Joseph H. 1981, p. 1365 apud Silva, Rafael Peteffi da p. 77.

${ }^{98}$ SILVA, Rafael Peteffi da. Op. Cit. p. 248.
} 
“...pois enorme seria a dificuldade de provar o nexo de causalidade certo e direito entre a falha médica ou hospitalar e a morte do paciente, já que este, muito provavelmente, morreria pela evolução endógena da doença, mesmo com uma conduta médica exemplar. Assim, a falha médica não se caracterizaria como uma condição necessária para o surgimento do dano" ${ }^{99}$.

No Brasil, Fernando Noronha, sobre a utilização do padrão "tudo ou nada", analisa que não parece ser essa a melhor solução, assim ponderando:

\begin{abstract}
"Cremos que são apenas parcialmente procedentes as críticas à extensão da teoria clássica aos casos de perda da chance de evitar que outrem sofresse um prejuízo, também nela se poderia ver "um instrumento de equidade que permite ao juiz ter um gesto em favor da vítima, todas as vezes que uma incerteza sobre o nexo de causalidade interdita uma reparação integral", como aliás, é opinião de outro jurista francês mui ilustre, Boris Srarck [1991, p. 60]."100
\end{abstract}

O doutrinador Fernando de Noronha analisa os casos de perda de uma chance na seara médica. Noronha analisa casos em que o paciente sofre agravamento no seu quadro clínico, podendo esse decorrer de tratamento inadequado ou da própria evolução da doença. Quando se conhece a causa do agravamento do paciente, não incide a responsabilidade civil pela perda de uma chance: se for culpa da conduta médica, haverá responsabilidade; caso contrário, se ficar comprovado que a conduta do médico não contribuiu para o dano, esse não responderá.

Contudo, se a causa do agravamento da enfermidade é desconhecida, mas também ocorreu uma falha no tratamento, sem se saber qual ocasionou o dano ao paciente, aqui surge a questão da responsabilidade civil pela perda de uma chance ${ }^{101}$. Aqui o dano ao paciente ocorreu por conta do tratamento inadequado e a evolução da doença, simultaneamente, ou resultou o dano somente de uma dessas causas, sem se saber qual. No primeiro caso, trata-se de situação de causalidade concorrente e, no segundo, de causalidade alternativa.

Noronha afirma que, se a produção do dano se der por conta de concorrência entre caso fortuito ou força maior, só irá responder o ofensor na

\footnotetext{
${ }^{99}$ Idem.

${ }^{100}$ NORONHA, Fernando. Op. Cit. p. 680.

${ }^{101}$ NORONHA, Fernando. Op. Cit. p.682.
} 
parcela do dano que pode ser atribuída à sua conduta, incidindo a causalidade concorrente. Na seara médica, por exemplo, quando se tem a evolução da própria doença do paciente e a deficiência no tratamento, podendo o dano ter resultado de um deles, ou atuado conjuntamente, ambos podem ser a causa adequada do dano.

Para Noronha, se aqui fosse aplicado o padrão do "tudo ou nada", e o fato de não haver prova o suficiente para apontar qual das possíveis causas provocou o dano acabar deixando a vítima sem reparação, seria injusto. "Se é sabido que o dano foi causado por um de dois fatos, e que pode até ter resultado da ação dois, não é razoável que o lesado fique sem reparação nenhuma." 102

Esse dano deverá ser reparado, sendo o responsável obrigado a reparar "uma fração do dano total, igual ao da probabilidade em que seu fato contribuiu para o dano". ${ }^{103}$ Dessa forma, exemplifica o autor: "...se a falha médica subtraiu dois terços das chances da vida da vítima, a reparação deve guardar a mesma proporção em relação ao dano final verificado" 104 .

Quanto à causalidade alternativa, Noronha preceitua que "a solução, nessas situações tem de seguir linhas paralelas às válidas nos casos de causalidade concorrente" ${ }^{105}$. Têm-se dois fatos que podiam ter dado causa ao dano, igualmente, mas isso não significa que o nexo de causalidade deva ser excluído por conta disto.

"E também aqui haverá que fazer um cálculo das probabilidades que cada um dos fatos postos em alternativa teria, na causação do dano. A reparação deve corresponder à porcentagem das chances com que o fato do responsável contribuiu para o final: esse será o valor da chance subtraída ao lesado. Em suma, o valor do dano deverá ser repartido na proporção em que cada um dos fatos em alternativa concorreu para o dano final" ${ }^{106}$.

\footnotetext{
${ }^{102}$ Ibid, p. 683.

${ }^{103}$ Idem.

${ }^{104}$ NORONHA, Fernando. Op. Cit. p. 683.

${ }^{105}$ Ibid., p. 676.

${ }^{106}$ Ibid., p. 684.
} 
Portanto, mesmo nas modalidades de perda de uma chance em que o processo aleatório chega ao seu final, o autor considera os prejuízos distintos e autônomos, divergindo da doutrina majoritária ${ }^{107}$.

Note que Noronha, no que tange à modalidade de perda da chance em que o processo aleatório chega ao seu final, utiliza-se dos institutos da causalidade concorrente e alternativa para aplicar a responsabilidade civil pela perda de uma chance. Noronha não menciona o conceito de causalidade parcial.

A causalidade alternativa atua por presunções ${ }^{108}$. Tais presunções são utilizadas para "inverter ou suavizar" o ônus probatório da conditio sine qua non, que, na maioria das vezes, cabe à vítima, possibilitando, dessa forma, a comprovação do nexo de causalidade entre a conduta do ofensor e o dano sofrido pela vítima. $\mathrm{O}$ instituto da causalidade alternativa ${ }^{109}$ é usado, em regra, para indenizar o dano final, ou seja, a vantagem final que era esperada pela vítima no processo aleatório, diferentemente da proposta de Noronha ao aplicar o instituto na perda das chances ${ }^{110}$.

Rafael Peteffi da Silva entende que, quanto à causalidade concorrente, essa não parece ser a solução mais adequada, já que a força maior e o caso fortuito, segundo o autor, não podem ser utilizados para dirimir a responsabilidade, apenas para excluí-la, ou seja, ou o ofensor responde integralmente pelo dano ou o caso fortuito ou força maior rompem o nexo de causalidade ${ }^{111}$. Assim, ou o caso fortuito rompe o nexo de causalidade, e o

\footnotetext{
${ }^{107}$ SILVA, Rafael Peteffi da. Op. Cit. p.109.

108 Ibid., p. 242.

${ }^{109}$ A causalidade alternativa também é aplicada em outra seara do direito civil, a responsabilidade civil dos grupos. O instituto é utilizado quando um grupo causa dano a terceiro, sem poder se identificar qual membro especificamente causou o dano. Nesses casos, o grupo responderá pelo dano de forma solidária. É possível citar aqui exemplo extraído do Tribunal do Rio Grande do Sul, em que em um desfile de carro alegórico, um carro, denominado "os caçadores", que homenageava o esporte da caça, efetuava disparos de festim, utilizando confete ao invés de chumbo. Ocorre que, dentre os tiros de festim, houve disparo de tiro real, com chumbo e confete, disparo este que acabou lesionando um homem que assistia o desfile de sua sacada. Perquiriu-se qual dos "caçadores" havia efetuado o disparo, porém todos negaram. Foi aplicado, portanto, a responsabilidade civil dos grupos, e todos os integrantes dos "caçadores" foram condenados solidariamente a indenizar a vítima, pois tinham o dever de guarda em relação às armas e munições.

Ibid., p. 48.

110 Ibid., p. 242.

${ }^{111}$ SILVA, Rafael Peteffi da. Op. Cit. p. 237/238.
} 
réu não responde, ou não existe prova suficiente que houve caso fortuito, e o réu, reparado o dano em sua integralidade, aplicando-se a regra do "tudo ou nada".

No entender de Peteffi da Silva, os casos de perda de uma chance são diferentes dos casos acima retratados de concorrência entre caso fortuito ou força maior e a conduta do ofensor. $\mathrm{O}$ autor baseia sua colocação em Jacques Boré, que afirma que "enquanto nos casos de predisposições patológicas se verifica a concorrência de duas condições necessárias para a efetivação do dano, nas hipóteses da teoria da perda de uma chance há os “efeitos prováveis de vários fatores igualmente prováveis"112.

Portanto, acredita Peteffi da Silva que a causalidade alternativa e a causalidade concorrente não apresentam os fundamentos mais adequados para a "tranquila aplicação sistemática em relação aos casos de responsabilidade pela perda de uma chance, nos quais o processo aleatório em que se encontrava a vítima foi até o seu final"113.

Por seu turno, em relação à causalidade parcial na perda de uma chance, assevera que "quando o processo aleatório chegou até final, como costuma acontecer na seara médica, a noção de causalidade parcial é chamada a depor"114. Por fim, Peteffi da Silva conclui que:

\footnotetext{
"Observando esses rígidos parâmetros, sem nunca olvidar da seriedade da chance perdida, a aplicação da teoria da perda de uma chance estaria de acordo com o novo paradigma solidarista. Visto por este ângulo e sob essas circunstâncias, é possível afirmar que a perda de uma chance, aplicada em hipóteses nas quais o processo aleatório chegou ao seu final, não depende de uma desvirtuação do nexo causal, mas de uma evolução deste" ${ }^{\prime 15}$.
}

O Autor faz a ressalva, entretanto, que a utilização da causalidade parcial deve ser uma exceção ao modelo atual da responsabilidade civil no direito brasileiro, devendo ser empregado como uma opção subsidiária,

\footnotetext{
${ }^{112}$ VINEY, genevieve; JOURDAN, patrice, 1998, p. 300/301 apud SILVA, Rafael Peteffi da p. 244.

${ }^{113}$ SILVA, Rafael Peteffi da. Op. Cit. p. 244.

${ }^{114}$ Ibid., p. 106.

Á$^{115}$ Ibid., p. 253.
} 
"somente após esgotadas as possibilidades da utilização ortodoxa do nexo causal" 116 .

Alexandre Martins de Castro e Maurilio Casas Maia, em recente artigo publicado na Revista de Direito do Consumidor, analisam que a teoria da perda de uma chance de cura, sobrevivência ou melhora da saúde, sofre um enfraquecimento da certeza do nexo de causalidade entre a conduta culposa do médico e o dano final sofrido pela vítima, "nunca sendo dispensada a certeza do nexo causal quanto ao dano da chance violada, dano esse distinto do retrocitado dano final" ${ }^{\prime 117}$.

\subsubsection{Chances Reais e Sérias}

Mister se faz ressaltar que não é qualquer chance perdida que será indenizada. Os danos meramente hipotéticos não devem ser reparados. Diante do caso concreto, é necessário que seja feita uma análise pelo magistrado para verificar se está diante de uma chance real e séria, conforme prelecionado pela jurisprudência francesa. No entanto, indaga-se: em que consiste a chance real e séria?

Para Sérgio Cavalieri Filho:

“A vantagem esperada pelo lesado não pode consistir numa mera eventualidade,
suposição ou desejo, do contrário estar-se-ia premiando os oportunismos, e não
reparando as oportunidades perdidas" (grifo original) ${ }^{118}$.
O jurista também recorda a importância do princípio da razoabilidade a ser aplicado nos casos de perda de uma chance.

Daniel Carnaúba faz a importante ressalva de que:

"A técnica de reparação das chances tem assim uma forte tendência à vulgarização [...] O método redundaria no direito ao sonho: o réu estaria obrigado a reparar todas

\footnotetext{
${ }^{116}$ SILVA, Rafael Peteffi da. Op. Cit. p. 246.

${ }^{117}$ MARTINS DE CASTRO, Alexandre; CASAS MAIA, Maurilio. Op. Cit. p.299.

${ }^{118}$ CAVALIERI FILHO, Sérgio. Op. Cit., p. 77.
} 
as aspirações da vítima; o único limite dessa dívida seria a imaginação do prejudicado"119.

Fernando Noronha assim analisa a questão:

"Para tal, em primeiro lugar importa averiguar se a chance perdida era real e séria: se for, haverá obrigação de indenizar; se ela tiver caráter meramente hipotético, não. E para se saber se a oportunidade era real e séria, haverá que recorrer às regras de experiência comum subministradas pela observação do que ordinariamente acontece, como se dispõe no art. 335 do Código de Processo Civil. ${ }^{120}$

A solução encontrada pela doutrina e jurisprudência italiana é aquela esposada por Bocchiola e utilizada pela Corte di Cassazione, na qual somente será possível se indenizar a chance perdida se a vítima demonstrar que a probabilidade de conseguir a vantagem esperada era superior a 50\% (cinquenta por cento) $)^{121}$.

Rafael Peteffi da Silva critica tal entendimento, observando que existem inúmeros casos, que apresentam razoável grau de certeza, em que a vítima tenha perdido menos de $50 \%$ das chances de alcançar a vantagem esperada. Esses casos, ao contrário do que o entendimento italiano consagra, devem ser indenizados, na visão do autor ${ }^{122}$.

Para Daniel Carnaúba, a técnica empregada de condicionar a reparação a uma porcentagem mínima, conforme feito na Itália, gera discriminações injustas e representa uma solução simplista e inadequada. "Não se pode ignorar que algumas oportunidades, conquanto inferiores a $50 \%$, podem representar interesses particularmente importantes para aqueles que as detêm"123. O Autor cita o exemplo de vestibulando que possui 20\% de chances de passar em faculdade de primeira linha, que valem muito mais do que $80 \%$ de chances de ser aprovado em instituição de pouco renome.

\footnotetext{
${ }^{119}$ CARNAÚBA, Daniel Amaral. Op. Cit., p. 123.

${ }^{120}$ NORONHA, Fernando. Op. Cit. p. 674.

${ }^{121}$ SAVI, Sérgio. Op. Cit. p. 31.

122 SILVA, Rafael Peteffi da. Op. Cit. p. 142.

${ }^{123}$ CARNAÚBA, Daniel Amaral. Op. Cit., p. 124.
} 
Apesar de as chances serem maiores em números, não se pode dizer que essa última seja mais séria do que a primeira ${ }^{124}$.

A jurisprudência francesa, que afirma que a chance deve ser real e séria, o que foi acolhido também pela doutrina, definiu dois elementos para serem levados em consideração nos casos envolvendo a perda de uma chance. O primeiro, as probabilidades envolvidas no caso, ou seja, quanto menores forem as probabilidades das chances perdidas, mais razões haverá para considerar a chance como irrelevante ou não séria; o segundo, a prova de que a chance em questão interessava efetivamente ao seu beneficiário. Assim, procura-se a prova de que aquela chance era realmente importante para a vítima e que a perda delaa representou uma lesão efetiva a um interesse seu. ${ }^{125}$

Rafael Peteffi da Silva descreve ainda o sistema adotado nos Estados Unidos. No caso de responsabilidade civil pela perda de uma chance, principalmente nos da seara médica, utiliza-se o padrão "more likely than not'. Tal padrão significa que, caso um procedimento médico retire $51 \%$ das chances de sobrevivência de um paciente, fica comprovada a existência do nexo de causalidade entre a conduta do agente e o dano, de forma a não incidir a teoria da perda de uma chance. Dessa forma, a teoria da perda de uma chance só seria aplicada nos casos em que se retirem menos de 50\% das chances de a vítima obter a vantagem esperada. Percebe-se que o padrão americano é quase o oposto daquele adotado na Itália ${ }^{126}$.

Portanto, tem-se que a chance perdida, para que seja indenizável, deve guardar estreita relação com a realidade, ou seja, deve constituir-se em autêntica oportunidade de sucesso e não apenas em mera suposição ou conjectura.

\subsubsection{A Quantificação da Indenização decorrente da Perda de uma Chance}

\footnotetext{
124 Ibid., p. 183.

${ }^{125}$ CARNAÚBA, Daniel Amaral. Op. Cit., p. 126.

${ }^{126}$ SILVA, Rafael Peteffi da. Op. Cit. p.141.
} 
À luz das informações contidas nas linhas acima, impõe-se dissecar a questão da quantificação da indenização decorrente da chance perdida. $\mathrm{O}$ valor da indenização não pode ser equivalente ao montante da vantagem final esperada pela vítima, devendo ser indenizadas apenas as chances perdidas. Essa é a regra fundamental da responsabilidade civil pela perda de uma chance.

Conforme examina Peteffi da Silva, é por conta dessa impossibilidade de reparar o dano final que a doutrina e jurisprudência, às vezes, afirmam que a reparação pela perda de uma chance viola o princípio da responsabilidade civil da reparação integral do prejuízo. Entretanto:

\begin{abstract}
“...isso não quer dizer que o dano pela perda de uma chance não esteja sujeito aos princípios da reparação integral; pelo contrário, a indenização concedida sempre repara de forma integral as chances perdidas, pois a perda de uma chance é um dano específico e independente em relação ao dano final, que era a vantagem esperada que foi definitivamente perdida" ${ }^{127}$.
\end{abstract}

Sobre a quantificação da indenização decorrente da perda de uma chance, Fernando Noronha assim preceitua:

“...nos casos em que a chance era real e séria, vai ser necessário estimar o valor desta. Para tal efeito, é preciso considerar a álea presente no caso concreto; o valor da chance só pode ser aferido através do cômputo do grau de probabilidade, que havia, de vir a concretizar-se o resultado que estava em expectativa. [...] A probabilidade poderá ser alta ou reduzida; poderá até ser tão desprezível que nem possa ser tida como correspondendo a um interesse digno de tutela jurídica, se se considerar a função social das obrigações" ${ }^{228}$.

E continua o ilustre doutrinador:

"A determinação do quantitativo a ser atribuído ao lesado vai depender da probabilidade, maior ou menor, que havia de que o resultado se concretizasse. Essa probabilidade há de ser traduzida numa porcentagem sobre o valor do dano total (ou dano final) que o lesado teria, se a vantagem desejada se concretizasse" 129 .

\footnotetext{
${ }^{127}$ Idem.

${ }^{128}$ NORONHA, Fernando. Op. Cit. p. 674.

129 Ibid., p. 675.
} 
Sérgio Savi, em análise acerca da Corte di Cassazioni e sua jurisprudência, preleciona que o juiz, para encontrar o valor da indenização, deve partir do dano final e fazer incidir sobre esse o percentual de probabilidade de obtenção da vantagem esperada. Para Savi, a forma de quantificação do prejuízo da perda de uma chance pode ser representada pela seguinte fórmula:

$$
\mathrm{VI}=\mathrm{VRF} \times \mathrm{Y}
$$

Em que VI representa o valor da indenização da chance perdida, VRF, o valor do resultado final e $\mathrm{Y}$, o percentual de probabilidade de obtenção do resultado final ${ }^{130}$.

Portanto, se o conjunto probatório demonstra que a probabilidade, por exemplo, de o recurso ser provido era de trinta por cento (30\%), e a vantagem esperada com a procedência da ação teria sido de dez mil reais, a indenização da perda da chance será quantificada em três mil reais ${ }^{131}$.

Jean-Pierre Couturier, através de conceito matemático, define a quantificação da indenização da chance perdida como "a função chance perdida" sendo derivada da "função vantagem esperada (dano final)" e varia conforme essa, mesmo mantendo a sua autonomia ${ }^{132}$.

Quanto à quantificação da chance perdida em si, Peteffi da Silva apresenta em Responsabilidade Civil pela Perda de uma Chance, Uma Análise do Direito Comparado e Brasileiro, a inovadora proposta de Paul Speaker, usando como modelo os casos da esfera médica, em que o processo aleatório chegou ao seu final. A fórmula desenvolvida por Speaker leva em conta a chance de a pessoa evitar o dano finalm representada por "x", e, após a conduta do réu, essa chance diminuída passa a ser representada por Y". Assim, a chance perdida é igual a $\mathrm{X}$ menos $\mathrm{Y}$, dividido por 1 menos $\mathrm{Y}^{133}$ :

\footnotetext{
${ }^{130}$ SAVI, Sérgio. Op. Cit. p. 32.

${ }^{131}$ CHATIER, Yves. apud Silva, Rafael Peteffi da. p. 28.

${ }^{132}$ COUTIRIER, Jean Pierre, p.160 apud Silva, Rafael Peteffi da. p. 144.

${ }^{133}$ SPEAKER, Paul. 2002 p.359 apud Silva, Rafael Peteffi da. p. 150.
} 


\section{$\mathrm{X}-\mathrm{Y} / 1-\mathrm{Y}$}

Tal fórmula apresenta resultado distinto do método tradicional utilizado para a quantificação da indenização nos casos de chance perdida. Para ilustrar a aplicação da fórmula, Peteffi descreve o caso de uma fábrica que contamina o lençol freático de uma cidade, sendo comprovado cientificamente que a ingestão da água aumenta a probabilidade dos bebês nascerem com Síndrome de Down. Comprovado cientificamente também é a taxa de nascimento de bebês com Síndrome de Down na cidade, de 1\%, antes do acidente que contamina a água. Após a contaminação, essa taxa passa a ser de $2 \%$.

Aplicando o método tradicional de quantificação, haveria um por cento de chances perdidas, dado que uma criança que possuía $99 \%$ de chance de viver, após a contaminação, passa a ter $98 \%$ de chances. Utilizando-se a fórmula de Paul Speaker, o resultado final seria de $50 \%$ de chances de sobreviver perdidas, já que, em cada dois bebês que nascem na cidade com Síndrome de Down, um teve como causa a contaminação da água pela fábrica.

$$
0,99-0,98 / 1-0,98=0,5
$$

Paul Speaker reconhece que a aplicação ideal da sua fórmula se dá no campo das ações coletivas. Peteffi da Silva pondera que a fórmula de Speaker tem aplicação mais adequada nos casos de perda de uma chance em que o processo aleatório chegou até o seu final, no qual a chance perdida não passa de uma parcela do dano final, verificada através da utilização da causalidade parcial. Já nos casos de perda de uma chance em que o dano seja autônomo e independente, o método clássico de quantificação deve ser utilizado, por apresentar características distintas ${ }^{134}$.

${ }^{134}$ SILVA, Rafael Peteffi da. Op. Cit. p. 154. 


\section{Capítulo 3. A Teoria da Perda de uma Chance no Direito Brasileiro}

\subsection{Manifestação da Doutrina}

Assim como na França, na Itália e nos Estados Unidos, o Direito brasileiro também teve que lidar com a álea no campo da responsabilidade civil $^{135}$. Os mesmos conflitos e indagações envolvendo a certeza do dano e o nexo de causalidade tiverem que ser enfrentados. Sérgio Savi e Pettefi da Silva reconhecem que a responsabilidade civil pela perda de uma chance não era muito debatida pela doutrina, havendo pouca produção doutrinária no país. No entanto, atualmente tal panorama tem se alterado largamente, embora para Sérgio Savi o tema ainda seja tratado de forma superficial por muitos doutrinadores brasileiros.

Posto isso, pode-se dizer que ampla é a aceitação da aplicação da teoria da perda de uma chance no Direito brasileiro, inobstante a ausência de previsão legal específica, em consonância com os princípios constitucionais como princípio da solidariedade, princípio da dignidade da pessoa humana e princípio da reparação integral dos danos.

O clássico doutrinador Agostinho Alvim enfrentou o tema da responsabilidade civil pela perda de uma chance, quando em 1955, analisou dois casos distintos: o primeiro sendo o de pessoa que vai participar de concurso que deve apresentar animal raro e permite que esse morra em acidente, por sua culpa. O segundo caso, no campo da responsabilidade civil do advogado, na hipótese em que esse perde prazo para interpor recurso contra sentença de juiz que mal apreciou a prova. Alvim reconhece haver dano diverso da perda da causa, sendo o dano aqui configurado a chance

${ }^{135}$ CARNAÚBA, Daniel Amaral. Op. Cit. p. 157. 
perdida de ver seu recurso ser apreciado pelo Tribunal ${ }^{136}$. Sobre a indenização de tal chance perdida, assim asseverou:

"O crédito valia dez. Suposta a sentença absolutória, que mal apreciou a prova, seu valor passou a ser cinco. Dado, porém, que a mesma haja transitado em julgado, tal valor desceu a zero. O prejuízo que o advogado ocasionou ao cliente, deixando de apelar, foi de cinco" $" 137$.

José de Aguiar Dias também tratou da teoria da perda de uma chance, analisando a responsabilidade civil do advogado. Trata-se de caso julgado pelo $1^{\circ}$ Tribunal de Alçada do Rio de Janeiro, em que Aguiar Dias denomina como "bisonho" o magistrado que decidiu que o advogado, no caso em tela, não era responsável pela perda do prazo, porque não havia dano configurado, sendo esse somente verificável caso o resultado do recurso fosse certo. Assim expôs o Autor:

\begin{abstract}
"Confundiram-se o an debeatur com o quantum debeatur, por má informação sobre o conceito de dano. Sem dúvida que este deve ser certo e provado desde logo na ação. Mas o dano, na espécie, era a perda de um direito, o de ver a causa julgada na instância superior. Se a vitória não podia ser afirmada, também o insucesso não o podia. E este, ainda que ocorresse, correspondia ao quantum debeatur, o que sucede mais vezes do que supõem os que desconhecem a distinção, pois, ainda que ganha uma causa, a liquidação pode ser negativa, isto é, não representar valor pecuniário ${ }^{138}$.
\end{abstract}

Aguiar Dias critica tal julgado, mas afirma que a prova do prejuízo, nesse caso, seria muito difícil de ser produzida pela vítima e, por isso, seria inadequado se falar em reparação ${ }^{139}$. O Autor acredita que a prova de que, se o recurso tivesse sido interposto, a sentença seria reformada, deve ser feita pela vítima, o que é impossível, já que se está no campo do álea.

J. M de Carvalho Santos ${ }^{140}$ também considera a perda de uma chance como lucro cessante e vai além, pois não vislumbra a existência de dano no

\footnotetext{
136 ALVIM, Agostinho Neves Arruda. Da inexecução das obrigações e suas consequências. $4^{\mathrm{a}}$. Edição São Paulo: Saraiva, 1972, p. 207/209.

${ }^{137}$ Idem.

${ }^{138}$ AGUIAR DIAS, José de. Op. Cit. p. 361.

${ }^{139}$ Ibid. p. 361/363.

${ }^{140}$ CARVALHO SANTOS., J. M de. Código Civil Brasileiro. Interpretado: principalmente sobre o ponto de vista prático. $11^{\text {a }}$ Edição, Rio de Janeiro: Freitas Bastos, 1964 p. 321/322.
} 
caso do advogado negligente que perde o prazo para recorrer, dado que a prova de que a sentença, caso interposto o recurso, seria efetivamente reformada seria impossível. Assim assinala o doutrinador: "parece duvidoso o direito do constituinte de poder exigir qualquer indenização, precisamente porque não lhe era possível provar o dano"141.

Sérgio Novais Dias foi o primeiro no Brasil a enfrentar a problemática da perda de uma chance no campo da responsabilidade civil do advogado. Novais Dias identifica a chance perdida como espécie de lucro cessante. Em sua obra, sustenta que, nos casos de recurso não interposto por negligência do advogado, se a matéria discutida não tinha nenhuma probabilidade de êxito, então a chance perdida não poderia ser considerada como dano patrimonial, devendo ser tratada como dano extrapatrimonial ou moral ${ }^{142}$.

Rafael Peteffi da Silva afirma que o Novais Dias, em sua obra, apresenta "exemplos poucos precisos". Ressalta que o doutrinador em questão não enfrenta a questão da quantificação da indenização decorrente da chance perdida expressamente, mas que, pelos exemplos colocados, levam a concluir que "a indenização que seria auferida pela vítima seria a totalidade da vantagem esperada, isto é, o dano final [...]"143.

Além dos já mencionados, outros doutrinadores brasileiros que se manifestaram favoráveis à teoria da perda de uma chance, incluem Caio Mário da Silva Pereira, Miguel Maria de Serpa Lopes, Sérgio Cavalieri Filho e Silvio Salvo Venosa, ressaltando todos que só será indenizável a chance séria e real, que tenha "probabilidade suficiente" e que o valor da indenização será menor do que a vantagem final almejada.

Caio Mário da Silva Pereira, sobre o tema, assim dispõe:

“'É claro, então, que se a ação se fundar em mero dano hipotético, não cabe reparação. Mas esta será devida se se considerar, dentro da ideia da perda de uma oportunidade (pert d'une chance) e puder situar-se a certeza do dano"144.

\footnotetext{
${ }^{141}$ Ibid. p. $321 / 322$.

${ }^{142}$ DIAS, Sergio Novais. Responsabilidade Civil do Advogado. São Paulo: Ltr, 1999 p. 67.

${ }^{143}$ SILVA, Rafael Peteffi da. Op. Cit. p. 195.

${ }^{144}$ PEREIRA, Caio Mário da Silva. Responsabilidade Civil. 4a ed. Rio de Janeiro: Forense, 2002 p. 42.
} 
Já Miguel Maria Serpa de Lopes, sobre a responsabilidade civil pela perda de uma chance, afirma que:

\begin{abstract}
"Tem-se entendido pela admissibilidade do ressarcimento em tais casos, quando a possibilidade de obter lucro ou evitar prejuízo era muito fundada, isto é, quando mais do que a possibilidade havia uma probabilidade suficiente, é de se admitir que o responsável indenize essa frustração. Tal indenização, porém, se refere à própria chance [...] Tudo quanto se impõe é a investigação judicial em torno das circunstâncias de que se revista cada caso, e apurar se delas emerge uma situação clara e definida, uma apreciação sobre a possibilidade perdida, se certa ou hipotética" ${ }^{145}$.
\end{abstract}

Sílvio Sálvio Venosa preceitua que a perda da chance pode ser considerada uma terceira modalidade de dano, "a meio caminho entre o dano emergente e o lucro cessante" 146 , e Sérgio Cavalieri Filho reconhece ser controvertida a questão, havendo aqueles que consideram a chance perdida como dano emergente, lucro cessante ou ainda dano moral. No entanto, ressalta que:

"De qualquer forma, a indenização deve corresponder à própria chance, que o juiz apreciará in concreto, e não ao lucro ou perda que dela era objeto, uma vez que o que falhou foi a chance, cuja natureza é sempre problemática na sua realização"147.

Outra autora ainda que é digna de menção e que, mais recentemente, realizou estudo aprofundado sobre o tema é foi Judith Martins-Costa, que em seus comentários sobre o Novo Código Civil, asseverou:

"Embora a realização da chance nunca seja certa, a perda da chance pode ser certa. Por estes motivos não vemos óbice à aplicação criteriosa da Teoria. O que o art. 403 afasta é o dano meramente hipotético, mas se a vítima provar a adequação do nexo causal entre a ação culposa e ilícita do lesante e o dano sofrido (a perda da probabilidade séria e real), configurados estarão os pressupostos de indenizar"148.

\footnotetext{
${ }^{145}$ SERPA LOPES, Miguel Maria de. Curso de Direito Civil, v.II: Obrigações em Geral. 7 ed. Revista e atualizada pelo Prof. José Serpa Santa Maria, Rio de Janeiro: Freitas Bastos, 2000, p. 391. ${ }^{146}$ VENOSA, Sílvio de Salvo. Direito civil: responsabilidade civil. 6. Ed. São Paulo: Atlas, 2006. p.272.

${ }^{147}$ CAVALIERI FILHO, Sérgio. Op. Cit. p. 80.

148 MARTINS COSTA, Judith. Comentários ao Novo Código Civil, v. V, tomo II: Do inadimplemento das Obrigações, coord. Sálvio Figueiredo Teixeira, Rio de Janeiro: Editora Forense, 2003, p.362.
} 
Sobre o tema, também realizaram trabalhos aprofundados Fernando Noronha, Rafael Peteffi da Silva e Sérgio Savi, os quais vêm sendo objeto de extensa análise no presente ensaio. Atualmente, o tema da teoria da perda de uma chance ainda se encontra em plena efervescência, sendo estudada inclusive a aplicação da teoria no âmbito do direito trabalhista e do direito de família $^{149}$.

Na doutrina moderna, mostra-se contrário à aceitação da teoria Rui Stoco. Sustenta o Autor que a perda de uma chance, aplicada aos casos de responsabilidade civil ao advogado, "para nós exsurge como inaceitável”, já que seria impossível prever qual seria a decisão do Tribunal ao analisar o recurso, profetizando-se a íntima convicção dos magistrados. Desse modo, aceitar a reparação nesses casos seria como se presumir que a decisão, caso o recurso intempestivo tivesse sido interposto a tempo, seria favorável. Para o doutrinador, estar-se-ia se responsabilizando o advogado por fato que não ocorreu, tratando-se de dano meramente hipotético, não comprovado, além de causar a reparação pelo resultado em uma obrigação contratual de meios. ${ }^{150}$

\subsection{Compatibilidade da Teoria com o Ordenamento Jurídico Brasileiro}

A teoria da perda de uma chance não está positivada em nosso ordenamento pátrio. No entanto, ampla é sua aceitação, sendo essa respaldada através de uma interpretação sistemática do Código Civil à luz dos princípios constitucionais.

Ademais, o Código Civil, em seu Capítulo II, do Título IX, que trata da indenização, assim dispõe em seus artigos 948 e 949:

\footnotetext{
${ }^{149}$ Para maior conhecimento sobre o tema vide : teoria da perda de uma chance aplicada ao Direito de Família: utilizar com moderação. Cristiano Chaves de Farias. In http://patriciafontanella.adv.br/wp-content/uploads/2011/01/artperdadechancedireitofamilia.pdf. E A perda da chance na justiça do trabalho: o dano moral na fase pré-contratual enquanto garantia fundamental. Luiz Henrique Mengon Dutra. In http://www.boletimjuridico.com.br/doutrina/texto.asp?id=2731

${ }^{150}$ STOCO, Rui. Tratado de Responsabilidade Civil. 6. ed. rev., atual. e ampl. São Paulo: Revista dos Tribunais, 2004. p.489/490.
} 
Art. 948. No caso de homicídio, a indenização consiste, sem excluir outras reparações:

I - no pagamento das despesas com o tratamento da vítima, seu funeral e o luto da família;

II - na prestação de alimentos às pessoas a quem o morto os devia, levando-se em conta a duração provável da vida da vítima

Art. 949. No caso de lesão ou outra ofensa à saúde, o ofensor indenizará o ofendido das despesas do tratamento e dos lucros cessantes até ao fim da convalescença, além de algum outro prejuízo que o ofendido prove haver sofrido. (grifo nosso)

Fazendo-se uma intepretação sistemática das regras de responsabilidade civil em nosso ordenamento, é possível sustentar que as chances perdidas devem ser indenizadas, desde que sérias e relevantes. Isso porque, assim como os Códigos Civis francês e italiano, o Código Civil brasileiro estabelece uma cláusula geral de responsabilidade civil, em que prevê a indenização para qualquer espécie de dano sofrido pela vítima, desde que preenchidos os requisitos que culminam no dever de indenizar ${ }^{151}$.

Além disso, o art. 402 CC assim estabelece:

Art. 402 CC Salvo as exceções expressamente previstas em lei, as perdas e danos devidas ao credor abrangem, além do que ele efetivamente perdeu, o que razoavelmente deixou de lucrar.

Através do referido dispositivo, tem-se o princípio da reparação integral dos danos. Tal princípio garante que haja um equilíbrio entre o dano e a reparação, para que seja restaurado, sempre que possível o status quo $a^{a n e^{152}}$. Deve, pois, a vítima ser reparada por todos os danos sofridos, dentre ele, as chances perdidas.

A aceitação da teoria da perda de uma chance no ordenamento jurídico brasileiro está em consonância com o novo paradigma no qual se insere a responsabilidade civil, que se baseia nos princípios da dignidade da pessoa humana e da solidariedade social.

${ }^{151}$ SAVI, Sérgio. Op. Cit. p. 106.

152 Idem. 
Maria Celina Bodin de Moraes, ao analisar o novo paradigma do Direito Civil, avalia a mudança de foco que ocorreu na seara da responsabilidade civil, voltando-se hoje todas as atenções para a vítima, ao invés do ofensor:

"O Direito Civil atual inverteu o polo e concentra-se na pessoa da vítima, considerando que, se alguém sofre um dano imerecido, faz jus, em princípio, à indenização. Houve, portanto, como já tantas vezes sublinhado, a inversão do fundamento geral de responsabilidade, que hoje tem por princípio geral a ideia de que 'a vítima não deve ficar irresarcida', em lugar da máxima que vigia anteriormente na matriz liberal, isto é, nenhuma responsabilidade sem culpa" ${ }^{\text {"153 }}$.

Logo, a fim de que a vítima não reste desamparada, deve ser indenizada a chance perdida. Sobre o dano decorrente da perda de uma chance, dispõe Savi:

\begin{abstract}
"A perda de uma chance, por sua vez, na grande maioria dos casos, será considerada um dano injusto e, assim, passível de indenização. Ou seja, a modificação do foco da responsabilidade civil, para a vítima do dano injusto, decorrente da evolução da responsabilidade civil, acaba por servir como mais um fundamento para a indenização desta espécie de dano. ${ }^{154 \text { ” }}$
\end{abstract}

\title{
Rafael Peteffi da Silva considera ainda outro elemento que favorece a
} reparação das chances perdidas, sendo esse os novos estudos sobre ciência estatística, além do progresso tecnológico.

Também se manifesta assim Sérgio Savi, citando Piero Calamandrei:

"Graças ao desenvolvimento do estudo das estatísticas e probabilidades, é possível hoje predeterminar, com uma aproximação mais que tolerável, o valor de um dano que, inicialmente, parecia entregue apenas à sorte, ao ponto de poder considerá-lo um valor normal, quase estável, dotado de uma certa autonomia em relação ao resultado definitivo.

Sendo assim, o recurso à estatística e ao estudo das probabilidades proposto por Calamandrei, mostra-se bastante útil, na medida em que permite verificar se antes da ocorrência do evento danoso já existia uma possibilidade com certo conteúdo patrimonial positivo para a vítima, a qual, após o evento danoso, restou perdida"155.

153 MORAES, Maria Celina Bodin de. Op. Cit. p. 131.

${ }^{154}$ SAVI Sérgio. Op. Cit. p. 119.

${ }^{155}$ Ibid., p. 20. 
Percebe-se, pois, que não há qualquer entrave para a adoção da teoria da perda de uma chance pelo Direito brasileiro. Pelo contrário, pode-se dizer que, negar a sua adoção, representaria verdadeiro retrocesso no campo da responsabilidade civil.

\subsection{Análise Jurisprudencial}

Analisando a jurisprudência sobre o tema, percebe-se que os tribunais brasileiros vêm aceitando a aplicação da teoria da perda de uma chance, que ganhou enorme popularidade, sendo recente a maioria dos julgados encontrados.

O primeiro acórdão brasileiro ${ }^{156}$, segundo Sérgio Savi, que pode ser encontrado que enfrente o tema da responsabilidade civil pela perda de uma chance é de 1990, do Tribunal de Justiça do Rio Grande do Sul, relatado pelo Desembargador Ruy Rosado de Aguiar Júnior, e assim está ementado:

RESPONSABILIDADE CIVIL. MÉDICO. CIRURGIA SELETIVA PARA CORREÇÃO DE MIOPIA, RESULTANDO NÉVOA NO OLHO OPERADO E HIPERMETROPIA. RESPONSABILIDADE RECONHECIDA, APESAR DE NAO SE TRATAR, NO CASO, DE OBRIGAÇÃO DE RESULTADO E DE INDENIZAÇÃO POR PERDA DE UMA CHANCE.

Como se pode verificar, embora a teoria aqui tenha sido analisada, essa não foi aplicada pelo Desembargador. O caso tratava de ação de indenização por conta de erro médico. A Autora havia se submetido a uma cirurgia de miopia em grau quatro da qual resultou em hipermetropia em grau dois. Além disso, a cirurgia a deixou com cicatrizes na córnea que deixavam uma névoa no olho operado.

Ao analisar o caso, pode-se identificar que os danos ocasionados eram consequências diretas e imediatas da conduta médica, havendo nexo de causalidade entre a conduta culposa do médico e o dano final e, por isso, não

\footnotetext{
${ }^{156}$ Tribunal de Justiça do Rio Grande do Sul, Quinta Câmara Cível, Apelação Cível Nº 589069996, Rel. Des. Ruy Rosado de Aguiar Júnior, Julgado em 12/06/1990.
} 
incidindo a teoria da perda de uma chance. Assim explicou o Des. Ruy Rosado de Aguiar Júnior em seu voto:

É preciso esclarecer, para efeito de cálculo de indenização, que não se trata de perda de uma chance, a que em certa passagem se referiu o apelante. Na perda da chance, não há laço de causalidade entre o resultado e a culpa do agente (François Chabas, "La Pertre d'une Chance en Droit Français"- palestra na Faculdade de Direito 23.05.90) : "On remarque, dan ces affaires, le traits comuns qui sont les caracteristiques du probleme: 1. Une faute de l'agent. 2. Un enjeu total perdu et qui pourrait être lê prejudice. 3 . Une absence de preuve du lieu de causalité entre la pertre de cet enjeu et la faute, parce que, par definition, cet enjeu est aleatoire. C'est une caracteristique essentielle de la question" 157.

Cerca de um ano depois, o Des. Ruy Rosado de Aguiar Júnior relatou outro caso em que a responsabilidade civil pela perda de uma chance também foi discutida. Nesse julgado, o dano da chance perdida foi reconhecido. Segue a ementa do caso concreto ${ }^{158}$.

RESPONSABILIDADE CIVIL. ADVOGADO. PERDA DE UMA CHANCE. AGE COM NEGLIGÊNCIA O MANDATÁRIO QUE SABE DO EXTRAVIO DOS AUTOS DO PROCESSO JUDICIAL E NÃO COMUNICA O FATO Á SUA CLIENTE NEM TRATA DE RESTAURÁ-LOS, DEVENDO INDENIZAR Á MANDANTE PELA PERDA DA CHANCE.

O caso tratava de ação de indenização proposta por autora que havia contratado o réu como seu advogado para ajuizar ação contra o INPS para que recebesse pensão previdenciária decorrente da morte de seu marido. A ação judicial, que fora distribuída em 1975, no Foro de Nova Hamburgo, para a $1^{\text {a }}$ Vara Cível, extraviou. Apesar de ciente do extravio, o advogado da autora nunca a informou sobre o ocorrido, e também não providenciou a restauração dos autos, de forma que a autora não pode buscar seus direitos.

\footnotetext{
157 Trecho Retirado de Savi, Sérgio. Op. Cit. p. 48. Em tradução livre: "Podemos perceber, nestes casos, os traços comuns que são as características do problema: 1. Uma falta do agente. 2. Uma chance perdida que poderia ser o dano. 3. Uma ausência de prova do nexo de causalidade entre a perda desta chance e a falta, porque por definição, esta chance é aleatória. É uma característica essencial da questão."

${ }^{158}$ Tribunal de Justiça do Rio Grande do Sul, Quinta Câmara Cível, Apelação Cível N 591064837, Relator: Ruy Rosado de Aguiar Júnior, Julgado em 29/08/1991.
} 
Foi reconhecido que a conduta do advogado fez com que a autora perdesse a chance de ver sua ação julgada e, com isso, sofreu dano representado pela chance perdida, devendo ser indenizada.

Oportuno se faz transcrever trecho do voto do relator acerca da indenização pela perda da chance da autora:

\begin{abstract}
"Não lhe imputo o fato do extravio, nem asseguro que a autora venceria a demanda, mas tenho por irrecusável que a omissão da informação do extravio e não restauração dos autos causaram à autora a perda de uma chance e nisso reside o seu prejuízo. Como ensinou o Prof. François Chabas: "Portanto, o prejuízo não é a perda da aposta (do resultado esperado), mas dá chance que teria de alcança-la." ('La Perte d'une chance em Droit Français', conferencia na Faculdade de Direito da UFRGS em 23.05.90) [...]

[...] a álea integra a responsabilidade pela perda de uma chance. Se fosse certo o resultado, não haveria a aposta e não caberia invocar este princípio específico da perda de uma chance, dentro do instituto da responsabilidade civil.
\end{abstract}

Isto posto, estou em negar o provimento ao apelo para manter a sentença de procedência, esclarecendo que a fixação da indenização, através de arbitramento, em liquidação de sentença, deverá atentar para o fato de que o dano corresponde apenas à perda da chance." ${ }^{159}$

A partir desse acórdão, apontados como os primeiros em todos os tribunais estaduais brasileiros, muitos outros julgados tratando sobre a responsabilidade civil pela perda de uma chance começaram a surgir. Nossa jurisprudência é, no entanto, ainda vacilante sobre o tema. Analisando os julgados produzidos em todo o país, percebe-se que não há uma uniformidade quanto ao que se entende pela perda de uma chance. A teoria, muitas vezes, é empregada de forma equivocada, sendo inobservada os seus requisitos, além de ainda ser controvertida a natureza jurídica da chance perdida. Além disso, é possível encontrar julgados que não aceitam a teoria. Abaixo, separou-se os julgados que apresentam equívocos na aplicação da teoria e aqueles que o fazem de forma correta e meticulosa.

\footnotetext{
159 Trecho do Voto do Des. Ruy Rosado de Aguiar na Apelação Cível Nº 591064837, Quinta Câmara Cível, Tribunal de Justiça do Rio Grande do Sul, Julgado em 29/08/1991.
} 


\subsubsection{A identificação do prejuízo a ser reparado como dano moral}

A técnica de reparação se propõe a indenizar os interesses aleatórios da vítima. Porém, há aqueles que confundem a perda de uma chance com um simples fato gerador de dano moral. A frustração de se ter uma chance perdida acarretaria simplesmente um dano moral à vítima, passível de indenização.

Nesse sentido:

Prestação de serviços advocatícios - Indenização por danos materiais e morais c.c. lucros cessantes - Indeferimento da inicial - Afastada a extinção do processo sem julgamento do mérito - Julgamento do mérito, nos termos do artigo 515 , § 30 do CPC - Negligência na prestação dos serviços, resultando no insucesso da demanda trabalhista ajuizada. - Alegação de que o advogado foi omisso ao não contatar o cliente para obter informação do local a ser realizada a perícia ambiental - Ausência de prova de que o autor foi devidamente cientificado para fornecer esta informação - Culpa do advogado demonstrada - Dever de indenizar apenas pelos danos morais, por "perda de uma chance" - Impossibilidade de fixação de danos materiais e lucros cessantes - Falhando o advogado em sua obrigação de meio ao deixar de informar nos autos o endereço necessário para a complementação da perícia, está a prejudicar o interesse de seu cliente. Ainda assim, não há possibilidade de fixação do valor do dano material por não se saber qual seria o eventual resultado se a informação tivesse sido prestada. Há dano moral, pois a falha profissional do advogado é causa de sofrimento para o cliente, que nele confiou e que sofre baixa de autoestima ao ver frustrada sua possibilidade de discutir o direito que entendia ter, ocorrendo a chamada "perda de uma chance". Afastada a extinção, acolhe-se parcialmente o pedido, para fixar indenização por dano moral, ante as especifícidades do caso, no valor equivalente a dez salários mínimos vigentes à época da fixação. - Ante a sucumbência recíproca, os honorários de advogado devem ser compensados entre as partes. - Recurso parcialmente provido, v.u (grifo nosso). ${ }^{160}$

O entendimento acima esposado coloca a perda de uma chance como fato que acarreta exclusivamente o dano moral. Não é analisado o interesse da vítima no aspecto material, se naquela chance perdida havia cunho patrimonial. Como bem adverte Daniel Carnaúba, "o entendimento em questão é uma nítida desnaturação da técnica." ${ }^{" 161} \mathrm{Na}$ responsabilidade civil pela perda de uma chance, procura-se indenizar o interesse que se tinha pela

\footnotetext{
160 Tribunal de Justiça de São Paulo, 35a Câmara de Direito Privado, Apelação Cível 9163372 31.2007.8.26.0000, Relator Manoel Justino Bezerra Filho, Data de Julgamento: 18/10/2010. No mesmo sentido: Apelação Cível 9245976-15.2008.8.26.0000, Tribunal de Justiça de São Paulo. ${ }^{161}$ CARNAÚBA, Daniel Amaral. Op.Cit. p.176.
} 
vantagem final esperada. A perda da chance de obter a vantagem, gerando frustrações, pode até ser indenizada como dano moral, mas esses dois danos são independentes, não se confundem e podem dar ensejo a reparações distintas.

Os magistrados acabam fazendo uso do conceito de dano moral para identificá-lo quando acharem oportuno, aplicando de forma inadequada a teoria da perda de uma chance e da própria técnica do dano moral.

Outro exemplo que pode ser citado em que a chance perdida foi enquadrada como dano moral de forma equivocada é o julgado do Tribunal de Justiça do Rio de Janeiro de $2003^{162}$ :

\begin{abstract}
MANDATO. RESPONSABILIDADE CIVIL DO ADVOGADO. INDENIZAÇÃO POR DANOS CAUSADOS EM VIRTUDE. DE PERDA DE PRAZO. DANOS MORAIS JULGADOS PROCEDENTES. A responsabilidade do advogado é contratual e decorre especificamente do mandato. Erros crassos como perda de prazo para contestar, recorrer, fazer preparo do recurso ou pleitear alguma diligência importante são evidenciáveis objetivamente. Conjunto probatório contrário a tese do Apelante. É certo que o fato de ter o advogado perdido a oportunidade de recorrer em consequência da perda de prazo caracteriza a negligência profissional. Da análise quanto à existência de nexo de causalidade entre a conduta do Apelante e o resultado prejudicial à Apelada resta evidente que a parte autora da ação teve cerceado o seu direito de ver apreciado o seu recurso à sentença que julgou procedente a reclamação trabalhista, pelo ato do seu mandatário, o qual se comprometera ao seu fiel cumprimento, inserido que está, no elenco de deveres e obrigações do advogado, aquele de interpor o recurso à sentença contra a qual irresignou-se o mandante. Houve para a Apelada a perda de uma chance, e nisso reside o seu prejuízo. Estabelecidas a certeza de que houve negligência do mandatário, o nexo de causalidade e estabelecido o resultado prejudicial demonstrado está o dano moral. RECURSO CONHECIDO E IMPROVIDO. (grifo nosso)
\end{abstract}

Em todos esses casos, ignora-se que a chance perdida pela vítima pode causar também danos de natureza patrimonial, cumulativamente ou não aos danos morais. Reitera-se que a perda de uma chance pode causar danos de naturezas distintas, de cunho patrimonial ou extrapatrimonial. O que se critica é o enquadramento do dano decorrente da perda de uma chance como

${ }^{162}$ Tribunal de Justiça do Rio de Janeiro, Décima Quarta Câmara Cível, Apelação Cível $n^{\circ}$ 2003.001.19138, Relator Des. Ferdinaldo do Nascimento, Data de Julgamento: 07/10/2003. 
exclusivamente moral, visto que na maioria das vezes a chance perdida possui natureza patrimonial, sendo considerada dano emergente.

\subsubsection{Equívocos na quantificação do dano a ser reparado}

Muitos julgados, apesar de reconhecerem a responsabilidade civil pela perda de uma chance, se equivocam quanto ao método de mensuração decorrente da chance perdida. Muitas vezes nem se menciona as probabilidades que estão em questão no caso concreto diante da vantagem esperada. Isso ocorre, por exemplo, nos casos acima tratados, quando se considera a perda de uma chance exclusivamente um dano moral. Cumpre examinarmos, nesse passo, o julgado abaixo:

AÇÃO DE REPARAÇÃO DE DANOS. Prestação de serviços advocatícios. Relação de consumo. Verificação. aplicação do prazo prescricional constante do art. 27 do CDC. Termo inicial da prescrição que deve ser contado a partir da data em que foi negado seguimento ao recurso. Prescrição não corporifiçada. Negativa de seguimento de recurso ordinário interposto em razão da intempestiva comprovação do recolhimento das custas. Falha incontroversa na prestação do serviço demonstrada. Decorrente impedimento de apreciação em instância superior que caracteriza perda de uma chance. Elementos objetivos que demonstram a viabilidade de provável sucesso. Prejuízo causado que exigem pronta reparação. Ausência de subsídios para a quantificação que impõe arbitramento em padrão razoável. [...] Demonstrada a realidade de eventual chance de sucesso por parte do apelante, inafastável que se imponha à apelada a obrigação de indenizar que, em não tendo aquele apresentado subsídios para a quantificação da provável perda, deve ser arbitrada dentro de um parâmetro de razoabilidade, ou seja, $\mathbf{R} \$ \mathbf{1 0 . 0 0 0 , 0 0}$ (dez mil reais), mais as despesas processuais (custas e todos os encargos). Recurso provido (grifo nosso). ${ }^{163}$

Há acórdãos ainda que, apesar de abordarem corretamente o conceito de perda de uma chance, indenizam a vítima no valor integral que representava a vantagem final esperada, em vez de indenizarem no valor equivalente a chance perdida. Segue exemplo abaixo:

RESPONSABILIDADE CIVIL. PROFISSIONAL LIBERAL. CONTRATAÇÃO DE SERVIÇOS ADVOCATÍCIOS. COMPROVADA NEGLIGÊNCIA POR

\footnotetext{
163 Tribunal de Justiça de São Paulo, 27a Câmara de Direito Privado, Apelação Cível 003438712.2008.8.26.0309, Relator Des. Dilmas Rubens Fonseca. Data de Julgamento: 05/04/2011.
} 
PARTE DOS RÉUS. DANO MATERIAL COMPROVADO NA FORMA DE LUCROS CESSANTES. CASO DE PERDA DA CHANCE. DANO MORAL INOCORRENTE. 1 . O caderno probatório comprova a conduta culposa dos réus, o que acarreta a responsabilidade de indenizar os prejuízos experimentados pela autora. 2. Os danos materiais suportados restaram comprovados, tendo em vista a análise detalhada da prova e a indenização foi fixada por equidade. [...] Assim, demonstrada a perda da chance da autora em ver-se ressarcida judicialmente pelos seus créditos trabalhistas, resta apenas quantificá-los. Nesse ponto, temse que o cotejo realizado com a ação movida [em caso semelhante] permite que se chegue a uma quantia aproximada do que receberia efetivamente a autora, técnica permitida pela aplicação da equidade ao caso. Recurso parcialmente provido (grifo nossso) ${ }^{164}$

Em casos como esses, em que, apesar de ser reconhecida a responsabilidade civil pela perda de uma chance, a vítima é indenizada pelo resultado final que esperava, há uma excessiva reparação. Conforme já visto neste ensaio, o valor da indenização pela chance perdida deve ser sempre inferior à vantagem que era almejada. Ninguém pode afirmar, por exemplo, no caso do advogado negligente que, caso o recurso tivesse sido interposto, esse teria sido provido, com certeza. As chances de êxito do recurso é que devem ser analisadas para quantificar-se a perda de uma chance.

Caso contrário, se fosse possível afirmar, com certeza, que caso o recurso tivesse sido interposto, esse seria provido, não se estaria mais na seara da responsabilidade civil pela perda de uma chance. Estaria presente o nexo de causalidade entre a conduta culposa do advogado e a perda da vitória na ação judicial, devendo a indenização ser quantificada pelos lucros cessantes, ou seja, a vítima seria indenizada pelo que lucraria com o êxito na ação judicial.

Sobre a responsabilidade civil do advogado, Sérgio Savi faz importante observação ao destacar que, com o advento da Emenda Constitucional $\mathrm{n}^{\circ} 45$ de 2004 e consequentemente a inserção da súmula vinculante, em alguns casos concretos de responsabilidade civil do advogado, será possível a condenação pelos lucros cessantes, como se a vítima de fato tivesse ganhado a demanda, e não pela chance perdida. Isso porque, com a

\footnotetext{
164 Tribunal de Justiça do Rio Grande do Sul, Primeira Turma Recursal Cível, Turmas Recursais, Recurso Cível No 71001196195, Relator: Ricardo Torres Hermann, Julgado em 12/07/2007.
} 
súmula vinculante, é sabido de antemão o posicionamento do Supremo Tribunal Federal acerca de determinada questão, e os Tribunais estão vinculados a tal entendimento. Então, no caso de recurso não interposto por conta de negligência do advogado, seria possível prever o resultado final caso o recurso tivesse sido interposto. Reitera-se que aqui não estará sendo aplicada a responsabilidade civil pela perda de uma chance ${ }^{165}$.

O Superior Tribunal de Justiça, acerca da quantificação da indenização decorrente da responsabilidade civil pela perda de uma chance, se manifestou em julgado proferido em 4 de dezembro de $2012^{166}$. Tratavase de caso de responsabilidade civil médica, relativo à perda de chance de cura, na qual o médico havia sido condenado pelo Tribunal de Justiça do Paraná, a indenização equivalente a morte do paciente. O Superior Tribunal de Justiça reformou a decisão, reiterando que o valor da indenização deve ser calculado em uma proporção sobre o dano final experimentado pela vítima. Dessa forma, o STJ reduziu o quantum indenizatório para $80 \%$ do valor, ponderando que: "Admitida a indenização pela chance perdida, o valor do bem deve ser calculado em uma proporção sobre o prejuízo final

\footnotetext{
${ }^{165}$ SAVI, Sergio. Op. Cit. p. 66.

166 STJ, REsp 1.254.141/PR, Rel. Min. Nancy Andrighi, julgado em 04.12.2012. DIREITO CIVIL. CÂNCER. TRATAMENTO INADEQUADO. REDUÇÃO DA POSSIBILIDADES DE CURA. ÓBITO. IMPUTAÇÃO DE CULPA AO MÉDICO.POSSIBILIDADE DE APLICAÇÃO DA TEORIA DA RESPONSABILIDADE CIVIL PELA PERDA DE UMA CHANCE. REDUÇÃO PROPORCIONAL DA INDENIZAÇÃO. RECURSO ESPECIAL PARCIALMENTE PROVIDO. 1. O STJ vem enfrentando diversas hipóteses de responsabilidade civil pela perda de uma chance em sua versão tradicional, na qual o agente frustra à vítima uma oportunidade de ganho. Nessas situações, há certeza quanto ao causador do dano e incerteza quanto à respectiva extensão, o que torna aplicável o critério de ponderação característico da referida teoria para a fixação do montante da indenização a ser fixada. Precedentes. 2. Nas hipóteses em que se discute erro médico, a incerteza não está no dano experimentado, notadamente nas situações em que a vítima vem a óbito. A incerteza está na participação do médico nesse resultado, à medida que, em princípio, o dano é causado por força da doença, e não pela falha de tratamento. 3. Conquanto seja viva a controvérsia, sobretudo no direito francês, acerca da aplicabilidade da teoria da responsabilidade civil pela perda de uma chance nas situações de erro médico, é forçoso reconhecer sua aplicabilidade. Basta, nesse sentido, notar que a chance, em si, pode ser considerado um bem autônomo, cuja violação pode dar lugar à indenização de seu equivalente econômico, a exemplo do que se defende no direito americano. Prescinde-se, assim, da difícil sustentação da teoria da causalidade proporcional.4. Admitida a indenização pela chance perdida, o valor do bem deve ser calculado em uma proporção sobre o prejuízo final experimentado pela vítima. A chance, contudo, jamais pode alcançar o valor do bem perdido. É necessária uma redução proporcional.5. Recurso especial conhecido e provido em parte, para o fim de reduzir a indenização fixada ${ }^{166}$. No mesmo sentido, STJ, REsp 1.184.128/MS, STJ - ERE 825037-DF, REsp 821004-MG, REsp 788459-BA.
} 
experimentado pela vítima. A chance, contudo, jamais pode alcançar o valor do bem perdido. É necessária uma redução proporcional. ”

\subsubsection{A Mera Possibilidade Não Pode Ser Indenizada}

Vale ratificar que somente a chance séria e real deve ser indenizada na responsabilidade civil pela perda de uma chance. É necessário que tais requisitos sejam observados para que não haja a banalização da teoria. Alguns julgados, no entanto, acabam determinando a indenização da chance perdida, sem essa chance ser real ou séria, e acabam-se prestigiando probabilidades corriqueiras e não sérias.

Em caso julgado pelo Tribunal de Justiça do Rio Grande do Sul ${ }^{167}$, em que se analisava a responsabilidade de advogado que perdeu o prazo para recorrer, foi determinada a indenização pela perda da chance, apesar de se ter reconhecido que as chances de êxito, caso o recurso houvesse sido interposto, eram mínimas.

Outro caso ainda, também julgado pelo Tribunal de Justiça do Rio Grande do $\mathrm{Sul}^{168}$, em que uma chance não séria e real foi indenizada, foi de

\footnotetext{
167 Tribunal de Justiça do Rio Grande do Sul, Décima Câmara Cível, Apelação Cível No 70006606487, Relator: Paulo Antônio Kretzmann, Julgado em 06/11/2003. Ementa: RESPONSABILIDADE CIVIL. DANO MORAL. ADVOGADO. RECURSO INTERPOSTO INTEMPESTIVAMENTE. PERDA DE UMA CHANCE. NEXO CAUSAL CONFIGURADO. INDENIZAÇÃO. MONTANTE. BENEFÍCIO DA GRATUIDADE. AUSÊNCIA. DESERÇÃO. 1. Responsabilidade civil do advogado que interpõe recurso fora do prazo legal. Alegação da ocorrência de greve por parte dos juízes federais, e conseqüente dedução de que houve a suspensão dos prazos processuais. Negativa de matrícula em disciplina na faculdade de Medicina. Mandado de segurança denegado. Hipótese de perda de uma chance a configurar o nexo causal ensejador de reparação do dano moral sofrido pela impetrante. 2. Valor fixado na sentença a título de ressarcimento por danos morais (10 salários mínimos) que permanece inalterado já que consentâneo com as circunstâncias do caso concreto e com os parâmetros adotados pela Câmara. 3. Em não havendo pedido anterior, e tampouco concessão do benefício da gratuidade, faz-se indispensável o pagamento das custas, juntamente com a interposição da apelação. Segundo a regra do art. 511 do CPC, o preparo deve ser comprovado no momento da interposição do recurso, sob pena de ser este considerado deserto. Ausência da comprovação da necessidade. Deserção verificada. Improveram os apelos da autora e do co-réu Luiz Carlos, e não conheceram do recurso do co-réu Guaraci.

168 Tribunal de Justiça do Rio Grande do Sul, Segunda Câmara Especial Cível, Apelação Cível No 70004650305, Relator: Mário Crespo Brum, Julgado em 19/12/2002. Ementa: ACIDENTE DE TRÂNSITO. CULPA CONCORRENTE. DANOS MORAIS. PENSIONAMENTO VITALÍCIO. AJUDA DE CUSTO. VINCULAÇÃO AO SALÁRIO MÍNIMO. PERDA DE UMA CHANCE. I - Vítima que confiou poder cruzar a via em segurança, já que o sinal estaria mudando, age de modo imprudente. II - Motorista que teve condições de ver a vítima, tendo, assim, também condições de acionar a buzina do veículo ou até mesmo acionar os freios, considerando a
} 
uma jovem atropelada que ficou com diversas sequelas, dentre elas, problemas na fala, cegueira e necessidade de ajuda para ler, escrever e caminhar. A jovem era revendedora de produtos de beleza e pretendia fazer curso de pedagogia ou informática. A vítima requereu indenização pelos danos sofridos, dentre eles o pagamento de pensão mensal vitalícia “com base na expectativa de ascensão profissional que tinha de passar de revendedora de produtos de beleza para pedagoga"169.

Em primeira instância, os pedidos da autora foram julgados parcialmente procedentes, por se entender haver concorrência de culpas no caso concreto. O réu foi condenado, portanto, a pagar, pela metade, todos os custos e gastos hospitalares, de tratamento médico, medicamentos e uma pensão vitalícia embasada na expectativa de sua ascensão profissional, com base no salário médio de uma pedagoga, além de indenização por danos morais no valor de 300 salários mínimos.

O Réu recorreu da decisão, contudo, e o Tribunal negou seguimento, confirmando a sentença de primeira instância.

Haveria equívoco na decisão acima proferida, pois, assim como bem apontado por Sérgio Savi ${ }^{170}$, apesar da gravidade do acidente, não se está diante de uma chance séria e real, quanto à condenação de pensão mensal vitalícia estimada em salário médio de pedagoga. A vítima tinha 19 anos, era revendedora de produtos de beleza e sequer estava participando de vestibular

\footnotetext{
baixa velocidade em que trafegava, já que lhe era previsível a possibilidade de ela vir, efetivamente, a tentar atravessar a avenida, como tentou fazer, despreza a cautela que se impunha. III - É sabido que a remuneração de prestador de serviços especializados ultrapassa em muito a soma de um salário mínimo, mormente considerando o fato de que, eventualmente, deverá a contratante também arcar com as despesas trabalhistas. Verba majorada. IV Sendo a vítima trabalhadora autônoma, revendendo produtos de beleza, é coerente a presunção de que auferisse, no mínimo, dois salários mínimos mensais a título de remuneração, restando evidente que teria ascensão profissional, visto que, na época do acidente, contava apenas 19 anos, estudava e tencionava fazer curso superior em Pedagogia. V - Acidente que a privou de uma chance plausível de ascensão profissional a médio prazo. VI A norma que veda a vinculação com o salário mínimo não incide na situação em apreço, visto que visa a impedir que o salário seja utilizado como indexador de preços e de tarifas, sendo que a lei proíbe a vinculação, e não a adoção do salário mínimo. Apelo desprovido e recurso adesivo parcialmente provido.
}

${ }^{169}$ SAVI, Sergio. Op. Cit. p. 63.

170 SAVI, Sergio. Op. Cit. p. 63. 
para qualquer universidade. Impossível dizer que a jovem iria, de fato, se torna-se uma pedagoga.

Infere-se, portanto, que o grande desafio, para que a técnica não receba abusos ou desnaturações, está em se definir critérios adequados para que somente as chances sérias e reais sejam indenizadas.

O Superior Tribunal de Justiça enfrentou tal problemática em acórdão ${ }^{171}$ sobre responsabilidade civil médica. A vítima falecera após se submeter a operação cardíaca, e era alegado que, por conta da negligência do médico no pós-operatório, o paciente havia sido privado de uma chance de sobrevida. Questionou-se ao perito do juízo se a morte de fato poderia ter sido evitada pelo médico, "caso tivesse havido acompanhamento médico mais próximo, no período pós-operatório", em que o perito respondeu: "Não há como fazer qualquer ilação. Mas é possível dizer que sim”. Com tal resposta, o Superior Tribunal de Justiça entendeu não se tratar de chance séria e real, afastando, portanto, a reparação.

Nesse julgado, o Superior Tribunal de Justiça definiu as balizas interpretativas na aplicação da teoria da perda de uma chance na área médica, sendo estas: (i) a atualidade e; (ii) certeza do dano em juízo de

\footnotetext{
${ }^{171}$ STJ, REsp 1104665/RS, Rel. Ministro Massami Uyeda, Terceira Turma, julgado em 09/06/2009, DJe 04/08/2009. RECURSO ESPECIAL - AÇÃO DE INDENIZAÇÃO - DANOS MORAIS ERRO MÉDICO - MORTE DE PACIENTE DECORRENTE DE COMPLICAÇ̃̃O CIRÚRGICA - OBRIGAÇÃO DE MEIO - RESPONSABILIDADE SUBJETIVA DO MÉDICO - ACÓRDÃO RECORRIDO CONCLUSIVO NO SENTIDO DA AUSÊNCIA DE CULPA E DE NEXO DE CAUSALIDADE - FUNDAMENTO SUFICIENTE PARA AFASTAR A CONDENAÇÃO DO PROFISSIONAL DA SAÚDE - TEORIA DA PERDA DA CHANCE - APLICAÇÃO NOS CASOS DE PROBABILIDADE DE DANO REAL, ATUAL E CERTO, INOCORRENTE NO CASO DOS AUTOS, PAUTADO EM MERO JUÍZO DE POSSIBILIDADE - RECURSO ESPECIAL PROVIDO I - A relação entre médico e paciente é contratual e encerra, de modo geral (salvo cirurgias plásticas embelezadoras), obrigação de meio, sendo imprescindível para a responsabilização do referido profissional a demonstração de culpa e de nexo de causalidade entre a sua conduta e o dano causado, tratando-se de responsabilidade subjetiva; II - O Tribunal de origem reconheceu a inexistência de culpa e de nexo de causalidade entre a conduta do médico e a morte da paciente, o que constitui fundamento suficiente para o afastamento da condenação do profissional da saúde; III - A chamada "teoria da perda da chance", de inspiração francesa e citada em matéria de responsabilidade civil, aplica-se aos casos em que o dano seja real, atual e certo, dentro de um juízo de probabilidade, e não de mera possibilidade, porquanto o dano potencial ou incerto, no âmbito da responsabilidade civil, em regra, não é indenizável; IV - In casu, o v. acórdão recorrido concluiu haver mera possibilidade de o resultado morte ter sido evitado caso a paciente tivesse acompanhamento prévio e contínuo do médico no período pós-operatório, sendo inadmissível, pois, a responsabilização do médico com base na aplicação da "teoria da perda da chance"; V - Recurso especial provido.
} 
probabilidade ${ }^{172}$, do que se extrai do seguinte trecho do acórdão:

\begin{abstract}
"A chamada "teoria da perda da chance", de inspiração francesa e citada em matéria de responsabilidade civil, aplica-se aos casos em que o dano seja real, atual e certo, dentro de um juízo de probabilidade, e não de mera possibilidade, porquanto o dano potencial ou incerto, no âmbito da responsabilidade civil, em regra, não é indenizável".
\end{abstract}

Outro julgado ${ }^{173}$ do Superior Tribunal de Justiça digno de menção é o REsp n ${ }^{\circ} 1115687 / \mathrm{SP}$, por reconhecer que:

“...somente a perda de uma oportunidade real, plausível e séria justifica a compensação por danos morais. Na hipótese dos autos, a chance de que fosse purgada a mora após a intimação pessoal dos devedores era remota e inexpressiva.":

Dessa feita, fica claro que a seriedade das chances perdidas devem ser analisadas para que haja reparação justa e adequada. A seriedade de uma chance pode decorrer de diversos fatores, dentre eles as probabilidades em questão. Consoante já esmiuçado, há quem seja a favor da técnica de adotar uma cifra única que determine a seriedade da chance. Sérgio Savi defende tal posicionamento em alinhamento com a doutrina e jurisprudência italiana, em que apenas as chances que representem uma probabilidade de êxito superiores a $50 \%$ devem ser reparadas ${ }^{174}$. Aquelas chances abaixo dessa cifra não receberiam a tutela do Direito.

O Superior Tribunal de Justiça não adota tal técnica, dado que os acórdãos não citam qualquer patamar mínimo ao abordarem a problemática

\footnotetext{
${ }^{172}$ MARTINS DE CASTRO, Alexandre; CASAS MAIA, Maurilio. Op. Cit. p.300.

173 STJ, REsp 1115687/SP, Rel. Ministra Nancy Andrighi, Terceira Turma, julgado em 18/11/2010, DJe 02/02/2011. DIREITO CIVIL. DANOS MORAIS. LEILÃO EXTRAJUDICIAL DE IMÓVEL REALIZADO NOS MOLDES DO DL 70/66. AUSÊNCIA DE INTIMAÇÃO PESSOAL DOS DEVEDORES. PERDA DA OPORTUNIDADE DE PURGAR A MORA. IMPROBABILIDADE DO PAGAMENTO. DANOS MORAIS. INDENIZAÇÃO INDEVIDA.1.É indispensável a intimação pessoal dos devedores acerca da data designada para o leilão do imóvel hipotecado em processo de execução extrajudicial realizado nos termos do DL 70/66. Precedentes. 2. Somente a perda de uma oportunidade real, plausível e séria justifica a compensação por danos morais. Na hipótese dos autos, a chance de que fosse purgada a mora após a intimação pessoal dos devedores era remota e inexpressiva.3. Recurso Especial parcialmente conhecido e provido.

${ }^{174}$ SAVI, Sérgio. Op. Cit., p. 80.
} 
da chance real e séria. Além disso, são diversos os precedentes que concedem reparações a chances perdidas cujas probabilidades de êxito eram menores que $50 \%{ }^{175}$

A questão já foi expressamente discutida no Recurso Especial $n^{\circ}$ 1.220.911-RS ${ }^{176}$, em que se afirmou que o percentual de $50 \%$ seria excessivamente elevado e que as hipóteses de perda de uma chance seriam indenizáveis mesmo quando as chances de se obter a vantagem final esperada fossem inferiores a tal cifra. Leia-se trecho do voto do Relator sobre tal ponto:

\begin{abstract}
A fim de criar um parâmetro objetivo, Sérgio Savi afirma que a teoria se aplica "apenas naqueles casos em que a chance for considerada séria e real, ou seja, em que for possível fazer prova de uma probabilidade de no mínimo 50\% (cinqüenta por cento) de obtenção do resultado esperado (...)" (in Responsabilidade Civil por Perda de uma Chance. São Paulo: Atlas, 2006, pp. 60/61).

Ainda que tal percentual não seja acolhido pela doutrina majoritária, por considerálo excessivamente alto, não pode se furtar o julgador da análise quanto à
\end{abstract}

\footnotetext{
175 Nesse sentido: STJ, REsp 788.459/BA; EDcl no AGRg no AI 1.916.957/DF; AgRg no REsp $1.220 .911 / \mathrm{SP}$.

${ }^{176}$ STJ, REsp 1.220.911-RS, Segunda Turma, Rel. Ministro Castro Meira, julgado em 17/03/2011, Data de Julgamento: 25/03/2011. Ementa: AGRAVO REGIMENTAL NO RECURSO ESPECIAL. PROCESSUAL CIVIL E DIREITO CIVIL. TEORIA DA PERDA DE UMA CHANCE. PRESSUPOSTOS INDENIZATÓRIOS.

ALEGADA VIOLAÇÃO DO ART. 159 DO CÓDIGO CIVIL. DANO MATERIAL HIPOTÉTICO. IMPOSSIBILIDADE. DANO MORAL. ACÓRDÃO A QUO BASEADO NO CONJUNTO FÁTICO-PROBATÓRIO. REVISÃO DE FATOS E PROVAS. SÚMULA No 07/STJ. 1. Cuida-se, na origem, de ação ordinária por meio da qual pretende o agravante ser indenizado pela União, em face dos danos materiais e morais sofridos em decorrência da sua reprovação no exame psicotécnico, com a consequente exclusão no concurso público destinado ao provimento de vagas para o cargo de Policial Rodoviário Federal. 2. O agravante logrou aprovação apenas na prova de conhecimento. Dessarte, ficaram pendentes as quatro fases seguintes da primeira etapa, compreendendo os seguintes exames: psicotécnico (considerando a inexistência de resultado válido), médicos, capacidade física e motricidade; e, ainda, a segunda etapa, de caráter eliminatório - Curso de Formação. 3. A pretensão não encontra amparo na "teoria da perda de uma chance" (perte d'une chance) pois, ainda que seja aplicável quando o ato ilícito resulte na perda da oportunidade de alcançar uma situação futura melhor, é preciso, na lição de Sérgio Cavalieri Filho, que: "se trate de uma chance real e séria, que proporcione ao lesado efetivas condições pessoais de concorrer à situação futura esperada" (Programa de Responsabilidade Civil, $4^{\mathrm{a}}$ ed., São Paulo: Malheiros, p. 92).4. Ademais, não se admite a alegação de prejuízo que elida um bem hipotético, como na espécie dos autos, em que não há meios de aferir a probabilidade do agravante em ser não apenas aprovado, mas também classificado dentro das 30 (trinta) vagas destinadas no Edital à jurisdição para a qual concorreu, levando ainda em consideração o nível de dificuldade inerente aos concursos públicos e o número de candidatos inscritos. 5. De mais a mais, o próprio autor afirma que não pretendia a investidura no cargo de Policial Rodoviário Federal, em face da sua nomeação para o de Procurador Federal. A pretensão não encontra guarida na teoria da perda de uma chance, aplicada somente "nos casos em que o ato ilícito tira da vítima a oportunidade de obter uma situação futura melhor, como progredir na carreira artística ou no trabalho, arrumar um novo emprego" (CAVALIERI FILHO, Sérgio. Op. cit., pp. 91-92) dentre outras. 6. Indevida indenização por dano moral, à míngua de efetiv comprovação, eis que o reexame dos aspectos de fato que lastreiam o processo, bem como sobre os elementos de prova e de convicção, encontra óbice no enunciado da Súmula 7/STJ, pois não há nos autos informação que justifique a condenação nessa verba. 7. Agravo regimental não provido.
} 
probabilidade do agravante de alcançar o bem almejado, caso o ato ilícito não lhe houvesse subtraído a chance alegada, ainda mais na circunstância como a que ora se analisa, em que o possível nem sempre é o provável. Como trazido a cotejo pelo agravante, o caso do "Show do Milhão", em que este Superior Tribunal reconheceu a perda da chance da participante em face de uma questão mal formulada, concluiuse que, em condições normais, a probabilidade de acerto seria de $1 \mathrm{em} 4$ (em face do número de alternativas possíveis). Mas o paradigma trazido à balha não guarda, é evidente, a mesma premissa fática dados autos, tanto por não se tratar de concurso público, como também pela viabilidade em demonstrar-se a existência de uma chance real e séria da parte autora em obter a vantagem almejada. Em suma, para fins de aplicação da teoria, não se admite a alegação de prejuízo que elida um bem hipotético, como no caso dos autos, em que não há meios de aferir a probabilidade do agravante em ser não apenas aprovado, mas também classificado dentro das 30 (trinta) vagas destinadas no Edital à jurisdição para a qual concorreu, levando ainda em consideração o nível de dificuldade inerente aos concursos públicos e o número de candidatos inscritos.

\section{O mesmo foi concluído no Enunciado $\mathrm{n}^{0} 444$ da $5^{\mathrm{a}}$ Jornada de Direito}

Civil, que assim dispõe sobre a chance indenizável: "deve ser séria e real, não ficando adstrita a percentuais apriorísticos"177.

Tal assertiva pode ser verificada ainda em recente julgado do Superior Tribunal de Justiça, o EDcl no AgRg no Ag 1196957/DF ${ }^{178}$ : Nesse caso, a

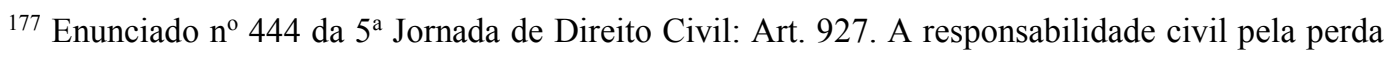
de chance não se limita categoria de danos extrapatrimoniais, pois, conforme as circunstâncias do caso concreto, a chance perdida pode apresentar também a natureza jurídica de dano patrimonial. A chance deve ser séria e real, não ficando adstrita a percentuais apriorísticos.

${ }^{178}$ STJ, EDcl no AgRg no Ag 1196957/DF, Rel. Ministra Maria Isabel Gallotti, Quarta Turma, julgado em 10/04/2012, DJe 18/04/2012. EMBARGOS DE DECLARAÇÃO. AGRAVO REGIMENTAL. AGRAVO DE INSTRUMENTO. OMISSÃO. E CONTRADIÇÃO. EXISTÊNCIA. SORTEIO. PROMOÇÃO PUBLICITÁRIA. VIOLAÇÃO DE DEVER CONTRATUAL. PERDA DE UMA CHANCE. 1. A recorrente recebeu bilhete para participar de sorteio em razão de compras efetuadas em hipermercado. Neste constava "você concorre a 900 vales-compras de $\mathrm{R} \$ 100,00$ e a 30 casas." Foi sorteada e, ao comparecer para receber o prêmio, obteve apenas um vale-compras, tomando, então, conhecimento de que, segundo o regulamento, as casas seriam sorteadas àqueles que tivessem sido premiados com os vale-compras. Este segundo sorteio, todavia, já tinha ocorrido, sem a sua participação. As trinta casas já haviam sido sorteadas entre os demais participantes. 2. Violação do dever contratual, previsto no regulamento, de comunicação à autora de que fora uma das contempladas no primeiro sorteio e de que receberia um segundo bilhete, com novo número, para concorrer às casas em novo sorteio. Fato incontroverso, reconhecido pelo acórdão recorrido, de que a falta de comunicação a cargo dos recorridos a impediu de participar do segundo sorteio e, portanto, de concorrer, efetivamente, a uma das trinta casas. 3. A circunstância de a participação no sorteio não ter sido diretamente remunerada pelos consumidores, sendo contrapartida à aquisição de produtos no hipermercado, não exime os promotores do evento do dever de cumprir o regulamento da promoção, ao qual se vincularam. 4. Dano material que, na espécie, não corresponde ao valor de uma das trinta casas sorteadas, mas à perda da chance, no caso, de 30 chances, em 900, de obter o bem da vida almejado. 5. Ausência de publicidade enganosa ou fraude a justificar indenização por dano moral. O hipermercado sorteou as trinta casas prometidas entre os participantes, faltando apenas com o dever contratual de informar, a tempo, a autora do segundo sorteio. Não é consequência inerente a qualquer dano material a existência de dano moral indenizável. Não foram descritas nos autos consequências extrapatrimoniais passíveis de
} 
empresa organizadora do sorteio falhou e a concorrente não foi informada de que se havia iniciado a segunda etapa do sorteio, na qual seriam sorteadas 30 casas entre os 900 participantes restantes. Note-se que as probabilidades da autora no caso em tela era de apenas $1 / 30$ de chances de obter o prêmio, mas o STJ, mesmo assim, reconheceu seu direito à indenização pela chance perdida, tratando essa como sendo séria e real.

À vista disso, infere-se que a seriedade da chance perdida deve ser analisada caso a caso, verificando-se a importância que a chance representava à vítima. Ademais, Rafael Peteffi da Silva evoca outro importante elemento que deve ser considerado quando se efetua análise da chance que foi perdida. Trata-se da proximidade temporal "do momento em que ocorreu o ato danoso que extinguiu as chances e o momento em que estas chances seriam utilizadas, na obtenção da vantagem esperada" ${ }^{179}$. Tal entendimento é corroborado pelo autor Daniel Amaral Carnaúba. Tal proximidade temporal significa dizer que há de ser avaliado se, no momento em que o dano é acarretado à vítima, essa esperava gozar da oportunidade em breve ou já a estava gozando. Nos casos em que não há esta referida proximidade temporal, o ônus probatório acaba sendo maior, para que reste comprovado a seriedade da chance perdida.

Daniel Carnaúba menciona ainda um terceiro elemento que deve ser considerado: a atitude da vítima com relação à chance perdida, "notadamente, se ela estava a se preparar para usufruir da chance adotando medidas capazes de permitir o seu gozo ou de ampliar suas probabilidades ${ }^{180}$.

Posto isso, pertinente à leitura de acórdãos de tribunais estaduais brasileiros que também aplicam a teoria da responsabilidade civil pela perda de uma chance de forma adequada. Esses analisam de forma ilustre a seriedade da chance perdida.

Digno de menção é acórdão da Apelação Cível nº 70005635750, julgado pelo

indenização em decorrência do aborrecimento de se ver a autora privada de participar do segundo sorteio. 6. Embargos de declaração acolhidos com efeitos modificativos.

179. SILVA, Rafael Peteffi da. Op. Cit. p.452/455.

${ }^{180}$ CARNAÚBA, Daniel Amaral. Op. Cit., p. 186. 
Tribunal de Justiça do Rio Grande do Sul ${ }^{181}$. Trata-se de caso de responsabilidade civil de advogado que interpõe apelação de forma intempestiva. Apesar de se reconhecer a teoria da perda de uma chance, considerou-se que essa não representava uma chance séria e real, já que a chance da sentença ser reformada era remota. Assim ponderou o Relator Des. Carlos Alberto Alvaro de Oliveira em seu voto:

Verifica-se, portanto, a perda de uma chance, pois, uma vez interposta em tempo a apelação, poderia em tese ocorrer mudança no resultado do julgamento em prol dos ora autores. Ademais, no dizer expressivo de Aguiar Dias (Da Responsabilidade Civil, vol. I, 10a. ed., Rio de Janeiro, Forense, 1997, n 128, p. 295), "A perda de prazo é a causa mais freqüente da responsabilidade do advogado. Constitui erro grave, a respeito do qual não é possível escusa, uma vez que os prazos são de direito expresso e não se tolera que o advogado o ignore."

Todavia, como bem acentua Sérgio Severo (Os Danos Extrapatrimoniais, São Paulo, Saraiva,1996, p.11 a 13), "A questão da perda de uma chance está inserida na esfera da certeza do dano, visando à indenização do dano causado quanto a vítima vê frustrada, por ato de terceiro, uma expectativa séria e provável, no sentido de obter um benefício ou de evitar uma perda que a ameaça". Por isso, adverte, invocando o ensinamento de Le Tourneau, "no que tange à indenização pela perda de uma chance é essencial que a mesma seja plausível e não aponte uma simples quimera" (...)" Trata-se da probabilidade de que o evento ocorresse; não fosse a intervenção do agente, esta chance deveria ser séria e viável" (...) Portanto, a chance deve ser considerável e não meramente eventual.

Ora, na espécie em julgamento, já havia, por um lado, a confissão quanto a matéria de fato, decorrente da revelia, e, por outro, no tocante à matéria de direito a cobrança de juros acima da Lei de Usura tem sido permitida nos negócios jurídicos bancários pela iterativa jurisprudência do Superior Tribunal de Justiça (v.g., REsp. $n^{\circ} .439828$, REsp. $n^{\circ} .430093$ e REsp. 337957). Além disso, os documentos de f. 163 a 169 não permitem outras ilações favoráveis aos apelantes. De resto, não ficou comprovado que a cobrança decorresse de valores indevidos, lançados sem fundamento na conta dos autores, ônus que incumbia aos autores. De ressaltar que a presente causa foi julgada antecipadamente, tendo os autores se contentado apenas com produção de prova documental, como se verifica da petição de f. 132. Em resumo, dada a imperícia e negligência do apelado pela não interposição do recurso, responde o advogado apenas pelos honorários que recebeu para o serviço que não desempenhou a contento e pelo preparo da apelação intempestiva.

\footnotetext{
${ }^{181}$ Tribunal de Justiça do Rio Grande do Sul, Sexta Câmara Cível, Apelação Cível No 70005635750 , Relator: Carlos Alberto Alvaro de Oliveira, Julgado em 17/09/2003. AÇÃ̃O DE REPARAÇÃO DE DANOS MATERIAIS E MORAIS. ALEGAÇÃO DE NEGLIGÊNCIA E IMPERICIA DE ADVOGADO, QUE SERIA RESPONSÁVEL PELA REVELIA E INTERPOSIÇÃO INTEMPESTIVA DE APELAÇÃO. PROVA QUE SÓ PERMITE CONCLUIR PELA CULPA DO PROFISSIONAL NA ÚLTIMA HIPÓTESE. PERDA DE UMA CHANCE. POSSIBILIDADE DE INDENIZAÇ̃̃O. NECESSIDADE, PORÉM, DA SERIEDADE E VIABILIDADE DA CHANCE PERDIDA. CIRCUNSTÂNCIAS NÃO PRESENTES NA ESPÉCIE. ACOLHIMENTO DO PEDIDO APENAS PARA CONDENAÇÃO DO PROFISSIONAL AO RESSARCIMENTO DOS HONORÁRIOS PAGOS PELOS AUTORES E PREPARO DO RECURSO INTEMPESTIVO. APELO EM PARTE PROVIDO (grifo nosso).
} 
Também cumpre citar acórdão do Tribunal de Justiça do Rio de Janeiro, na Apelação Cível $n^{0}$ 2003.001.16559, ${ }^{182}$ que aplicou de forma correta a responsabilidade civil pela perda de uma chance. A reparação, no caso em tela, foi negada pois se entendeu que não se estava diante de uma chance séria e real, além de não ter sido preenchido o requisito de certeza dos danos. $\mathrm{O}$ caso tratava de nome do autor que havia sido mantido de forma indevida no cadastro de maus pagadores e que, por essa razão, não conseguiu obter empréstimo que seria utilizado para quitar as dívidas de sua empresa.

Destaque-se o voto do Relator ao tratar da teoria da perda de uma chance:

Na pert d'une chance, todavia, o fato ilícito e culposo deve contribuir, de forma direta, para que outrem peça uma chance de conseguir um lucro ou de obter uma vantagem ou de evitar um prejuízo.

Contudo, é necessário que a chance perdue seja real e séria, tendo-se em conta, também, na avaliação dos danos, a alea susceptível de comprometer tal chance:

182 Tribunal de Justiça do Rio de Janeiro, Sexta Câmara Cível, Apelação Cível 2003.001.16559, Relator Des. Pestana de Aguiar, Data de Julgamento: 17/09/2003. Ementa: CIVIL. RESPONSABILIDADE CIVIL, DANO MORAL. RESTRIÇÃO AO CRÉDITO. ARQUIVO PRIVADO. DANO MATERIAL. PERDA DE UMA CHANCE. A simples abertura de arquivo de consumo, com anotações pessoais sobre a pessoa do consumidor, constitui violação dos direitos fundamentais do cidadão (art. $5^{\circ}$, incisos X, XIV, XXXIII e LXXII da Constituição Federal), A manutenção, sem qualquer dúvida, viola muito mais, dando margem, assim, à reparação civil. Por conseguinte, a manutenção do nome do autor no órgão particular protetivo pelo]'apelante, como é óbvio e notório, foi a causa direta e imediata da revolta, do aborrecimento, o vexame, e do constrangimento suportados pelo autor, situações estas configuradoras do dano moral. Evidente, portanto, que o dano injusto causado à reputação subjetiva do autor, além de ter apequenado a sua dignidade, gerou, também, a dor e o sofrimento, violentando, por fim, a sua própria honorabilidade moral, vinculando o responsável ao dever de indenizar, Se, por um lado, é preciso não deixar que a invocação do ato ilícito sirva de pretexto ao enriquecimento injusto da vítima, por outro, faz-se imperioso que não se avilte de tal modo o montante da indenização do ponto de não desestimular a conduta danosa, de não impingir alguma baixa nos contas do responsável pela lesão, Conseqüentemente, à falta de critério objetivo ou legal, a indenização do dano moral deve fazer-se por arbitramento, com ponderação e racionalidade, levando-se em conta a natureza do lesão, as condições da vítima e o atuar ilícito do agente. Há de orientar-se o juiz pelos critérios sugeridos pela doutrina e pela jurisprudência, com razoabilidade, curando, quando o caso não exigir sanção pecuniária predominantemente punitiva, para que não enriqueça a vítima à custa do injusto, Na pert d'une chance, todavia, o fato ilícito é culposo deve contribuir, de forma direta, para que outrem perca uma chance de conseguir um lucro ou obter uma vantagem ou de evitar um prejuízo. Contudo, é necessário que a chance perdue seja real e séria, tendo-se em conta, também, na avaliação dos danos, a alea susceptível de comprometer tal chance. Deve-se ter em conta, assim, não apenas a existência do fator alea, mas também o grau dessa alea, ou seja, leva-se em consideração, quanto à prova, o caráter atual ou eminente da chance de que o autor alega ter sido privado, Tratando-se de sucumbência parcial, impõe-se a aplicação do regra prevista no parágrafo único do art. 21 do Código de Processo Civil. SENTENÇA CORRETA. IMPROVIMENTO DE AMBOS OS RECURSOS. 
leva-se em consideração, quanto à prova, o caráter atual ou eminente da chance de que o autor alega ter sido privado.

No caso em exame, o primeiro apelante não trouxe aos autos qualquer documento, qualquer outra prova indicativa de que, de fato, as tratativas com a CEF se encontravam em estágio avançado, a tal ponto poder ser afirmado que a concessão do empréstimo era, sem qualquer dúvida, uma chance real e séria.

A mera expectativa, a simples eventualidade, o decadente esperado não tipificam, por certo, a chance perdida, a perda irreparável.

Assim, como bem posiciona o douto Julgador de primeiro grau, em face da não comprovação de tal condição, repita-se, para tal enquadramento, ratifica-se também a não concessão de verba específica em relação a esse tópico.

\subsubsection{A Teoria da Perda de uma Chance no STJ}

\subsubsection{Os primeiros casos no STJ}

Um dos primeiros casos em que a responsabilidade civil pela perda de uma chance foi discutida pelos Ministros do Superior Tribunal de Justiça foi o Recurso Especial n ${ }^{0} 57.529 / \mathrm{DF}^{183}$. Conforme se depreende da leitura do julgado, trata-se de ação proposta por empresa de alimentos contra empresa área, pois essa última realizou viagem em nome da parte autora para se apresentar ao ato público de concorrência para aquisição de alimentos, levando consigo amostras que eram necessárias para participar do certame. Ocorre que houve extravio de bagagem, e as amostras não puderam ser exibidas, de forma que a autora foi excluída da concorrência. A autora pleiteou, dessa forma, as despesas gastas com a viagem, além da reparação do dano decorrente do extravio da bagagem e indenização pela perda da concorrência que "certamente venceria em razão dos menores preços que ofereceu, conforme documentação que juntou".

Em primeira instância, o pedido foi julgado parcialmente procedente, deferindo-se apenas o montante de 150 BTNs, conforme artigos 248 e 260 da Lei 7.565/86, Código Brasileiro de Aeronáutica). A autora apelou, e o

\footnotetext{
${ }^{183}$ TRANSPORTES AEREO. - E LIMITADA, NOS TERMOS DA LEGISLAÇÃO ESPECIAL, A RESPONSABILIDADE DA EMPRESA TRANSPORTADORA, EM CASO DE EXTRAVIO DE BAGAGEM DURANTE A EXECUÇÃO DO CONTRATO DE TRANSPORTE. - RECURSO ESPECIAL NÃO CONHECIDO. MAIORIA. REsp 57.529/DF, Rel. Ministro RUY ROSADO DE AGUIAR, Rel. p/ Acórdão Ministro FONTES DE ALENCAR, QUARTA TURMA, julgado em 07/11/1995, DJ 23/06/1997.
} 
recurso foi parcialmente provido para elevar o valor da condenação. $O$ Tribunal de Justiça do Distrito Federal entendeu que a responsabilidade da empresa área se encontrava limitada pelo Código Brasileiro de Aeronáutica e que, além disso, o pedido de lucros cessantes não poderia ser acolhido visto que se estava diante de um dano hipotético, dado que não havia como afirmar com certeza que a parte autora sairia vitoriosa do certame.

Contra esse acórdão foi interposto Recurso Especial, relatado pelo Ministro Ruy Rosado de Aguiar, que conheceu o recurso e lhe deu provimento, por entender incidir a responsabilidade pela perda de uma chance. No entanto, o ilustre ministro foi voto vencido, tendo sido mantida a decisão do Tribunal de Justiça do Distrito Federal. Não obstante, cumpre transcrever trecho do voto do relator, que aborda o tema da perda de uma chance:

A autora pretende a indenização pela perda de uma chance. $\mathrm{O}$ tema tem sido versado em outros países, especialmente na França, onde a doutrina, incentivada por decisões da Corte de Cassação, admite a necessidade de ser responsabilizado o autor da ação ou da omissão que causa a outrem a perda de uma oportunidade real de alcançar uma vantagem ou evitar um prejuízo, nas mais diversas situações jurídicas $[\ldots]$

Mme. Viney examina e rebate as objeções opostas a esta hipótese de responsabilização: o caráter futuro do dano não se constitui em empecilho para que se admita a responsabilidade civil, sendo comum nos casos de danos contínuos, como na indenização por incapacidade física, ou por morte do obrigado a prestar alimentos, etc. A oportunidade, a chance de obter uma certa situação futura é uma realidade concreta, ainda que não seja a real concretização dessa perspectiva; é um fato do mundo, um dado da realidade, tanto que o bilhete de loteria tem valor, o próprio seguro repousa sobre a ideia de chance. A dificuldade de sua avaliação não é maior do que avaliar o dano moral pela morte de um filho, ou o dote devido à mulher agravada em sua honra (art. 1548 do CC). É preciso, porém, estabelecer linhas limitadoras: a chance deve ser real e séria; o lesado deve estar efetivamente em condições pessoais de concorrer à situação futura esperada; deve haver proximidade de tempo entre a ação do agente e o momento em que seria realizado $\mathrm{o}$ ato futuro: a reparação deve necessariamente ser menor do que o valor da vantagem perdida (Viney, Genevieve, La responsabilité, in Traité de Droit Civil, Jacques Ghestin, LGDJ, 1982, 341 e seguintes).

No caso dos autos, estão reconhecidos os pressupostos de fato para o reconhecimento da responsabilidade da transportadora: houve o extravio da bagagem mencionada pela autora, que por isso deixou de participar da concorrência que se realizava naquele dia. Apenas que a eg. Camara julgou inexistir o direito à reparação quando há somente a perda de uma chance, situação não prevista em lei. 
Penso que tal decisão causa ofensa do disposto no artigo 159 do Código Civil, clausula geral que contempla inclusive a hipótese da perda de uma real oportunidade de obtenção de uma certa vantagem. Não se indeniza a vantagem de quem venceria a concorrência, mas a perda real da oportunidade de concorrer, que é um fato provado, causador de prejuízo de não concorrer, e por isso incluído no âmbito do artigo 159 do CC, pois foi causado por culpa da transportadora.

O Ministro Sálvio de Figueiredo Teixeira, apesar de não ter dado provimento ao recurso, admitiu a aplicação da teoria da responsabilidade civil por perda de uma chance nesse julgado. Desse modo, esse foi um dos primeiros julgados do Superior Tribunal de Justiça que enfrentou a teoria da perda de uma chance.

Outra decisão proferida pelo Superior Tribunal de Justiça que foi uma das primeiras a discutir a perda de uma chance foi a $\mathrm{AG} \mathrm{n}{ }^{0} 272.635-\mathrm{SP}^{184}$, julgada em 11/02/2000, em que o Ministro Eduardo Ribeiro julgou o Agravo de Instrumento em caso de responsabilidade civil de advogado que perde o prazo para interpor recurso, contra sentença desfavorável de seu cliente. Assim dispõe o Ilustre Ministro Relator:

Em sua inicial, pediu o autor que a indenização pelos danos suportados com a conduta desidiosa dos advogados fosse equivalente ao que pleiteava na ação trabalhista. O tribunal de origem entendeu que, embora provada a culpa do primeiro réu, o pedido seria improcedente porque incertos os danos pleiteados. Concluiu-se que o autor deveria ter requerido indenização pelo fato de ter perdido a chance de ser vencedor em sua demanda.

De fato, houve-se com acerto o corte estadual. A condenação em perdas e danos pressupõe a prova efetiva do gravame suportado pelo requerente. No presente caso, não há como se estabelecer se o autor teria sua pretensão julgada procedente em sua totalidade. É possível que sua vitória fosse apenas parcial. Do mesmo modo, a outra parte poderia ser a vencedora. Está-se, portanto, diante de uma possibilidade de dano, mas não há certeza quanto a sua efetiva ocorrência, ou quanto à sua extensão, razão pela qual há de ser mantida a decisão recorrida.

Infere-se, portanto, da leitura do voto do Relator, que a teoria da perda de uma chance teria sido acolhida, e o Autor teria sido indenizado, caso esse tivesse sido o pedido formulado em sua demanda.

${ }^{184}$ STJ. Agravo Regimental no 272.635/SP. Relator: Min Eduardo Ribeiro. Data de julgamento: $11 / 02 / 2000$. 
Sérgio Savi faz importante ressalva nesse ponto. Aduz Savi que, nos casos em que o Autor formula pedido de reparação pelos lucros cessantes, o juiz deverá verificar a intenção do Autor - se essa foi a indenização pela perda de uma chance, ainda que esse a tenha qualificado erroneamente como lucros cessantes - deve o magistrado julgar o pedido procedente e qualificar o dano como dano emergente. No entanto, caso se constate que o Autor ambicionava a indenização somente pelos lucros cessantes, pela vantagem final esperada, então deve o juiz julgar o pedido improcedente, pois a perda de uma chance não caracteriza os lucros cessantes.

Por fim, Savi aconselha que para se precaver, o melhor é fazer pedidos alternativos na inicial, pleiteando-se os lucros cessantes ou, caso o juiz entenda não haver certeza quanto ao dano, a indenização pela perda de uma chance $^{185}$.

\subsubsection{O acolhimento da teoria - Leading Case Show do Milhão}

O famoso caso Show do Milhão ${ }^{186}$ é apontado como leading case na jurisprudência brasileira, no qual se pode dizer que o Superior Tribunal de Justiça de fato acolheu a teoria da perda de uma chance. O Recurso Especial $\mathrm{n}^{\mathrm{o}}$ 788.459-BA foi julgado em 08 de novembro de 2005.

A demanda foi interposta por participante de programa de perguntas e respostas do canal televiso SBT, denominado "Show do Milhão", que pleiteou indenização pelos danos materiais e morais sofridos em decorrência do ocorrido em sua participação no programa. O "Show do Milhão" consiste

\footnotetext{
${ }^{185}$ SAVI, Sérgio. Op. Cit. p. 95.

186 STJ, REsp 788.459/BA, Rel. Ministro Fernando Gonçalves, Quarta Turma, julgado em 08/11/2005, DJ 13/03/2006. RECURSO ESPECIAL. INDENIZAÇÃO. IMPROPRIEDADE DE PERGUNTA FORMULADA EM PROGRAMA DE TELEVISÃO. PERDA DA OPORTUNIDADE.1. O questionamento, em programa de perguntas e respostas, pela televisão, sem viabilidade lógica, uma vez que a Constituição Federal não indica percentual relativo às terras reservadas aos índios, acarreta, como decidido pelas instâncias ordinárias, a impossibilidade da prestação por culpa do devedor, impondo o dever de ressarcir o participante pelo que razoavelmente haja deixado de lucrar, pela perda da oportunidade. 2. Recurso conhecido e, em parte, provido.
} 
em concurso de perguntas e respostas, cujo prêmio máximo é um milhão de barras de ouro, concedido ao participante que acertar um número determinado de questões sobre conhecimentos gerais. A autora havia brilhantemente acertado as perguntas, chegando à última indagação, conhecida como "pergunta do milhão". Ao se deparar com tal pergunta, a autora preferiu não responder a ela, para salvaguardar o prêmio já acumulado de quinhentos mil reais. Pois, caso errasse a "pergunta do milhão", iria perder o valor já conquistado. Todavia, a autora considerou que a ré teria agido de má-fé, pois para a "pergunta do milhão" formulada, não havia resposta correta. Assim eram os termos da referida pergunta:

"A Constituição reconhece direitos aos índios de quanto do território brasileiro?" Resposta 1) 22\% Resposta 2) 2\% Resposta 3) 4\% Resposta 4) 10\%?

A pergunta formulada de fato não possui resposta, tendo em vista que não há na Constituição Federal qualquer passagem que designe uma porcentagem do território nacional aos povos indígenas.

A ré, em sua defesa, sustentou que haveria resposta correta para pergunta formulada, já que o artigo 231 da Constituição Federal assim dispõe:

São reconhecidos aos índios sua organização social, costumes, línguas, crenças $e$ tradições, e os direitos originários sobre as terras que tradicionalmente ocupam, competindo à União demarcá-las, proteger e fazer respeitar todos os seus bens.

Portanto, alega a Ré que se a autora soubesse a área do território nacional e a quantidade de terras que os índios ocupam, poder-se-ia responder à pergunta.

Ocorre que, conforme apontado na sentença, à ré não assiste razão, porque a "pergunta do milhão" deixa claro que na Constituição Federal haveria porcentagem expressa de terras pertencentes aos indígenas, o que não é verdade. Ademais, assim ainda conclui o magistrado do caso: "nem poderia fazê-lo, eis que, até hoje, a União não concluiu o processo de levantamento e de demarcação do território indígena, havendo, inclusive, até os dias atuais, tribos ainda desconhecidas vivendo nos grotões das selvas brasileiras". 
Em primeira instância, dessa forma, o pedido autoral foi acolhido quanto ao dano material, já que se entendeu que de fato não haveria resposta para a referida pergunta. A sentença tem como fundamento a teoria da perda de uma chance. Apesar disso, a ré foi condenada ao pagamento de quinhentos mil reais, a títulos de danos materiais, valor esse que a autora receberia caso tivesse acertado a pergunta.

Foi interposta apelação pela empresa ré, tendo sido negado provimento ao recurso pelo Tribunal de Justiça da Bahia. Contra o acórdão, interpôs-se recurso especial na qual a ré sustentou que o valor da condenação havia sido excessivo, visto que as chances da autora responder corretamente à "pergunta do milhão" eram de $25 \%$, tendo em vista haver quatro alternativas para a resposta. Assim, o valor da indenização deveria ser de cento e vinte e cinco mil reais e não de quinhentos mil reais. Tal argumento foi acolhido pelo Superior Tribunal de Justiça.

O equívoco do programa causou dano à autora. No entanto, o prêmio de um milhão de reais que ela almejava não passava de uma probabilidade, uma incerteza.

O Ministro Fernando Gonçalves, relator do caso, entendeu que se tratava de hipótese de responsabilidade civil pela perda de uma chance, dando provimento ao Recurso Especial. Necessária se faz a leitura de parte do voto do Relator, que expõe de forma muito clara a questão:

Na espécie dos autos, não há, dentro de um juízo de probabilidade, como se afirmar categoricamente - ainda que a recorrida tenha, até o momento em que surpreendida com uma pergunta no dizer do acórdão sem resposta, obtido desempenho brilhante no decorrer do concurso - que, caso fosse o questionamento final do programa formulado dentro de parâmetros regulares, considerando o curso normal dos eventos, seria razoável esperar que ela lograsse responder corretamente à "pergunta do milhão".

Isto porque há uma série de outros fatores em jogo, dentre os quais merecem destaque a dificuldade progressiva do programa (refletida no fato notório que houve diversos participantes os quais erraram a derradeira pergunta ou deixaram de respondê-la) e a enorme carga emocional que inevitavelmente pesa ante as circunstâncias da indagação final (há de se lembrar que, caso o participante optasse por respondê-la, receberia, na hipótese, de erro, apenas $\mathrm{R} \$ 300,00$ (trezentos reais).

Destarte, não há como concluir, mesmo na esfera da probabilidade, que o normal andamento dos fatos conduziria ao acerto da questão. Falta, assim, pressuposto 
essencial à condenação da recorrente no pagamento da integralidade do valor que ganharia a recorrida caso obtivesse êxito na pergunta final, qual seja, a certeza - ou a probabilidade objetiva - do acréscimo patrimonial apto a qualificar o lucro cessante.

Não obstante, é de se ter em conta que a recorrida, ao se deparar com questão mal formulada, que não comportava resposta efetivamente correta, justamente no momento em que poderia sagrar-se milionária, foi alvo de conduta ensejadora de evidente dano.

Resta, em consequência, evidente a perda de oportunidade pela recorrida, seja ao cotejo da resposta apontada pela recorrente como correta com aquela ministrada pela Constituição Federal que não aponta qualquer percentual de terras reservadas aos indígenas, seja porque o eventual avanço na descoberta das verdadeiras condições do programa e sua regulamentação, reclama investigação probatória e análise de cláusulas regulamentares, hipóteses vedadas pelas súmulas 5 e 7 do Superior Tribunal de Justiça.

Quanto ao valor do ressarcimento, a exemplo do que sucede nas indenizações por dano moral, tenho que ao Tribunal é permitido analisar com desenvoltura e liberdade o tema, adequando-o aos parâmetros jurídicos utilizados, para não permitir o enriquecimento sem causa de uma parte ou o dano exagerado de outra.

A quantia sugerida pela recorrente ( $\mathrm{R} \$ 125.000,00$ cento e vinte e cinco mil reais) - equivalente a um quarto do valor em comento, por ser uma "probabilidade matemática" de acerto de uma questão de múltipla escolha com quatro itens) reflete as reais possibilidades de êxito da recorrida.

Sérgio Savi, ao comentar caso, considera o referido acórdão "quase impecável" e "merecedor de nossos aplausos pela forma técnica em que foi elaborado"187. A única ressalva do Autor é quanto aos limites da aplicação da teoria da perda de uma chance, já que Savi é adepto do entendimento de que a chance para ser considerada séria e real e, portanto, indenizável, deve ser aquela superior a $50 \%$, ou seja, que tem mais de $50 \%$ de probabilidade de lograr êxito. No caso do "Show do Milhão", as chances da autora eram de $25 \%$ de êxito, e dessa maneira, a chance perdida não deveria ser indenizada. Contudo, o Autor pondera:

"Não há como afirmar que o acórdão está equivocado neste ponto. A diferença entre o entendimento esposado pelo STJ no caso do show do milhão e aquele por nós defendido neste livro, é tão somente, em relação ao critério a ser adotado" ${ }^{188}$.

${ }^{187}$ SAVI, Sérgio. Op. Cit., p. 79.

${ }^{188}$ Ibid., p. 80. 
Já Rafael Peteffi da Silva, apesar de reconhecer a importância do julgado, por esse representar a consagração da teoria da perda de uma chance pelo Tribunal que tem a responsabilidade de dar a última palavra nas questões infraconstitucionais, entende que a indenização da autora deveria ter sido maior. Para o autor,

“...é forçoso admitir que, no caso em tela, qualquer pessoa, mesmo uma criança em tenra idade ou um amental, teria, matematicamente, ao menos $25 \%$ de chances de acertar a derradeira pergunta do programa televiso".

\title{
E conclui:
}

"Como a vítima havia mostrado, durante o próprio programa, impressionante conhecimento enciclopédico, acreditamos que, mesmo levando em conta o elevado grau de complexidade da "pergunta do milhão", a indenização deveria ter ficado um pouco acima dos $25 \%$ concedidos no julgamento final" 189 .

\subsubsection{A Consolidação da Teoria}

\author{
Após o importante julgamento do leading case do "Show do Milhão", \\ outros casos foram enfrentados pelo Superior Tribunal de Justiça que \\ merecem ser destacados.
}

Um deles é o Recurso Especial n ${ }^{0}$ 1.079. 1850- $\mathrm{MG}^{190}$, relatado pela Ministra Nancy Andrighi, em que se reconheceu a possibilidade da perda de

\footnotetext{
${ }^{189}$ SILVA, Rafael Peteffi da. Op. Cit. p. 205.

${ }^{190}$ STJ, REsp 1079185/MG, Rel. Ministra Nancy Andrighi, Terceira Turma, julgado em 11/11/2008, DJe 04/08/2009. Caso semelhante REsp no ${ }^{\circ}$. 965.758- RS. PROCESSUAL CIVIL E DIREITO CIVIL. RESPONSABILIDADE DE ADVOGADO PELA PERDA DO PRAZO DE APELAÇÃO. TEORIA DA PERDA DA CHANCE. APLICAÇÃO. RECURSO ESPECIAL. ADMISSIBILIDADE. DEFICIÊNCIA NA FUNDAMENTAÇÃO. NECESSIDADE DE REVISÃO DO CONTEXTO FÁTICO-PROBATÓRIO. SÚMULA 7, STJ. APLICAÇÃO. - A responsabilidade do advogado na condução da defesa processual de seu cliente é de ordem contratual. Embora não responda pelo resultado, o advogado é obrigado a aplicar toda a sua diligência habitual no exercício do mandato. - Ao perder, de forma negligente, o prazo para a interposição de apelação, recurso cabível na hipótese e desejado pelo mandante, o advogado frusta as chances de êxito de seu cliente. Responde, portanto, pela perda da probabilidade de sucesso no recurso, desde que tal chance seja séria e real. Não se trata, portanto, de reparar a perda de "uma simples esperança subjetiva", nem tampouco de conferir ao lesado a integralidade do que esperava ter caso obtivesse êxito ao usufruir plenamente de sua chance. - A perda da chance se aplica tanto aos danos materiais quanto aos danos morais. - A hipótese revela, no entanto, que os danos materiais ora pleiteados já tinham sido objeto de ações autônomas e que o dano moral não pode ser majorado por deficiência na fundamentação do recurso especial. - A pretensão de simples reexame de prova
} 
uma chance dar origem a danos de natureza jurídica distintas: patrimoniais e extrapatrimoniais.

Trata-se de caso de advogado que perde prazo de interposição de recurso de sua cliente, agindo de forma negligente. A autora requereu o ressarcimento pelos danos morais e materiais sofridos.

Reconheceu-se a possibilidade de indenização pela teoria da perda de uma chance. Destaca-se trecho do voto da Ministra da Nancy Adrighi:

Diante deste panorama, a doutrina tradicional sempre teve alguma dificuldade para implementar, em termos práticos, a responsabilidade do advogado. Com efeito, mesmo que comprovada sua culpa grosseira, é difícil antever um vínculo claro entre esta negligência e a diminuição patrimonial do cliente, pois o que está em jogo, no processo judicial de conhecimento, são apenas chances e incertezas que devem ser aclaradas em um juízo de cognição. Em outras palavras, ainda que o advogado atue diligentemente, o sucesso no processo judicial depende de outros favores não sujeitos ao seu controle. Daí a dificuldade de estabelecer, para a hipótese, um nexo causal entre a negligência e o dano.

Para solucionar tal impasse, a jurisprudência, sobretudo de direito comparado, e a doutrina passaram a cogitar da teoria da perda da chance. A aludida teoria procura dar vazão para o intricado problema das probabilidades, com as quais nos deparamos no dia-a-dia, trazendo para o campo do ilícito aquelas condutas que minam, de forma dolosa ou culposa, as chances, sérias e reais, de sucesso às quais a vítima fazia jus.

Não se trata, portanto, de reparar a perda de "uma simples esperança subjetiva", nem tampouco de conferir ao lesado a integralidade do que esperava ter caso obtivesse êxito ao usufruir plenamente de sua chance (Rafael Peteffi da Silva. Responsabilidade Civil pela Perda de uma Chance. São Paulo: Atlas, 2007, p. 134).

É preciso ressaltar que, naturalmente, há possibilidades e probabilidades diversas e tal fato exige que a teoria seja vista com o devido cuidado. No mundo das probabilidades, há um oceano de diferenças entre uma única aposta em concurso nacional de prognósticos, em que há milhões de possibilidades, e um simples jogo de dado, onde só há seis alternativas possíveis.

Assim, a adoção da teoria da perda da chance exige que o Poder Judiciário bem saiba diferenciar o "improvável" do "quase certo", a "probabilidade de perda" da "chance de lucro", para atribuir a tais fatos as consequências adequadas (REsp 965.758/RS, 3a Turma, minha relatoria, DJe 03/09/2008)

não enseja recurso especial. Aplicação da Súmula 7, STJ. - Não se conhece do Especial quando a decisão recorrida assenta em mais de um fundamento suficiente e o recurso não abrange todos eles. Súmula 283, STF. Recurso Especial não conhecido. 
Quanto à possibilidade da perda de uma chance dar origem a danos de natureza jurídica distintas: patrimoniais e extrapatrimoniais, assim colocou a Ilustre Ministra Nancy Adrighi:

\begin{abstract}
A sentença, nesse ponto mantida pelo Tribunal de origem, posiciona-se na tese de que a aplicação da teoria da perda da chance só pode levar ao ressarcimento por danos morais.

Com a devida vênia aos entendimentos contrários, a probabilidade perdida pode ter contornos materiais bem definidos, que só não são relevantes nesta hipótese porque o pedido encontra-se bem delimitado e, além disso, como demonstrei, tais prejuízos foram objetos de ações diversas. Destaco a recente doutrina sobre o tema:

“(...) não há dúvida de que, em determinados casos, a perda da chance, além de representar um dano material, poderá, também, ser considerada um 'agregador' do dano moral. $\mathrm{O}$ que não se pode admitir é considerar o dano da perda de chance como sendo um dano exclusivamente moral" (Sérgio Savi. Responsabilidade civil por perda de uma chance. São Paulo: Atlas, 2006, p. 53).
\end{abstract}

O Julgado acima exposto deve ter sua importância reconhecida já que a tendência nos Tribunais Estaduais, em sua maioria, é de indenizar a perda de uma chance como dano moral. E, em tal decisão, foi reconhecida a perda de uma chance como dano patrimonial.

Para fins didáticos, cumpre analisar outros julgados do Superior Tribunal de Justiça que revelam aspectos importantes da responsabilidade civil pela perda de uma chance. O Recurso Especial n ${ }^{0} 1.190 .180-$ RS $^{191}$ é um deles.

191 STJ, REsp 1190180/RS, Rel. Ministro Luis Felipe Salomão, Quarta Turma, julgado em 16/11/2010, DJe 22/11/2010. Ementa: RESPONSABILIDADE CIVIL. ADVOCACIA. PERDA DO PRAZO PARA CONTESTAR. INDENIZAÇÃO POR DANOS MATERIAIS FORMULADA PELO CLIENTE EM FACE DO PATRONO. PREJUÍZO MATERIAL PLENAMENTE INDIVIDUALIZADO NA INICIAL. APLICAÇÃO DA TEORIA DA PERDA DE UMA CHANCE. CONDENAÇÃO EM DANOS MORAIS. JULGAMENTO EXTRA PETITA RECONHECIDO.1. A teoria da perda de uma chance (perte d'une chance) visa à responsabilização do agente causador não de um dano emergente, tampouco de lucros cessantes, mas de algo intermediário entre um e outro, precisamente a perda da possibilidade de se buscar posição mais vantajosa que muito provavelmente se alcançaria, não fosse o ato ilícito praticado. Nesse passo, a perda de uma chance - desde que essa seja razoável, séria e real, e não somente fluida ou hipotética - é considerada uma lesão às justas expectativas frustradas do indivíduo, que, ao perseguir uma posição jurídica mais vantajosa, teve o curso normal dos acontecimentos interrompido por ato ilícito de terceiro. 2. Em caso de responsabilidade de profissionais da advocacia por condutas apontadas como negligentes, e diante do aspecto relativo à incerteza da vantagem não experimentada, as demandas que invocam a teoria da "perda de uma chance" devem ser solucionadas a partir de uma detida análise acerca das reais possibilidades de êxito do processo, eventualmente perdidas em razão da desídia do causídico. Vale dizer, não é o só fato de o advogado ter perdido o prazo para a 
O referido julgado, além de ratificar o entendimento do Superior Tribunal de Justiça acerca da teoria da perda de uma chance, enfrenta a questão do pedido autoral formulado apenas pleiteando os lucros cessantes e não contempla o pedido de indenização pela perda de uma chance. No caso concreto, a Autora havia requerido indenização no montante esperado desde que obtivesse êxito no processo de execução, ou seja, apenas pediu os danos materiais sofridos. O Tribunal de Justiça do Rio Grande do Sul julgou o pedido parcialmente procedente e condenou os advogados réus que haviam atuado com negligência ao pagamento de $\mathrm{R} \$ 25.000,00$, a título de danos morais, com base na teoria da perda de uma chance.

O Recurso Especial foi interposto pelos réus perante o Superior Tribunal de Justiça com a alegação de que o autor não havia pedido indenização por danos morais nem por danos decorrentes da perda de uma chance, classificando a decisão proferida pelo TJRS como extra petita. O STJ deu provimento ao Recurso dos advogados negligentes, determinando que o TJRS fizesse outro julgamento, observando os limites estabelecidos no pedido autoral ${ }^{192}$.

contestação, como no caso em apreço, ou para a interposição de recursos, que enseja sua automática responsabilização civil com base na teoria da perda de uma chance. É absolutamente necessária a ponderação acerca da probabilidade - que se supõe real - que a parte teria de se sagrar vitoriosa. 3 . Assim, a pretensão à indenização por danos materiais individualizados e bem definidos na inicial, possui causa de pedir totalmente diversa daquela admitida no acórdão recorrido, de modo que há julgamento extra petita se o autor deduz pedido certo de indenização por danos materiais absolutamente identificados na inicial e o acórdão, com base na teoria da "perda de uma chance", condena o réu ao pagamento de indenização por danos morais.4. Recurso especial conhecido em parte e provido.

${ }^{192}$ Leia-se a ementa do acórdão do novo julgamento do TJRS acerca do caso: APELAÇÃO CÍVEL. AÇÃO DE INDENIZAÇÃO. PREJÚIZZOS CAUSADOS EM RAZÃO DE MANDATO. SERVIÇOS ADVOCATÍCIOS. Agravo retido. Inépcia da inicial. Descabimento. Pretensão deduzida na inicial está embasada em prejuízos concretos, inclusive havendo constrição judicial em bens do demandante. Prestação de serviços profissionais. Patrocínio faltoso de advogado pode resultar em duas situações: na primeira, ajuíza-se ação indenizatória decorrente de perda de chance cujos danos são hipotéticos e com base em juízo de probabilidade; na segunda, ajuíza-se ação indenizatória por danos materiais cujos danos devem ser certos quanto à sua ocorrência. No caso dos autos, não há prova concreta da extensão dos danos materiais eventualmente suportados por ocasião do patrocínio defeituoso dos advogados. O ônus probatório quanto à extensão dos danos é de incumbência apenas da parte autora, nos termos do que dispõe o art. 333, inc. I, do CPC. Ônus da sucumbência: Invertidos. NEGARAM PROVIMENTO AO AGRAVO RETIDO E DERAM PROVIMENTO ÀS APELAÇÕES. UNÂNIME. Tribunal de Justiça do Rio Grande do Sul, Décima Sexta Câmara Cível, Apelação Cível No 70016193252, Relator: Ergio Roque Menine, Julgado em $15 / 12 / 2011$. 
O erro do autor, portanto, foi formular seu pedido somente quanto aos danos materiais pela vantagem que esperava auferir com a vitória da sua demanda, pressupondo a certeza do provimento do seu recurso.

Cumpre observar também que, nesse Recurso Especial, o Superior Tribunal de Justiça se posicionou no sentido de que o dano decorrente da perda de uma chance possui natureza material, estando ele entre o dano emergente e o lucro cessante. Portanto, o dano à chance poderia ser considerado como uma terceira categoria lesiva:

\begin{abstract}
"A teoria da perda de uma chance (perte d'une chance) visa à responsabilização do agente causador não de um dano emergente, tampouco de lucros cessantes, mas de algo intermediário entre um e outro, precisamente a perda da possibilidade de se buscar posição mais vantajosa que muito provavelmente se alcançaria, não fosse o ato ilícito praticado". Desta forma, reconheceu o STJ uma natureza peculiar a chance perdida, em que o dano decorrente da chance perdida estaria situado entre o dano emergente e o lucro cessante, categoria inédita no ordenamento jurídico brasileiro.
\end{abstract}

Convém ainda analisar o já mencionado REsp 1.254.141/ PR ${ }^{193}$, porém sob outro enfoque. Tal acórdão, relatado pela Ilustre Ministra Nancy Andrighi, é de suma importância, tendo abordado diversos aspectos relevantes sobre a teoria da perda de uma chance. Além de representar acórdão em que a indenização da chance perdida foi quantificada de forma correta, esse também apontou a distinção entre a teoria da perda de uma chance clássica e a teoria da perda de uma chance na seara médica.

Cite-se, à guisa de exemplo, o juiz federal Márcio André Calvacante do TRF-1 ${ }^{a}$ região, que afirmou que, na teoria clássica da perda de uma chance, "há sempre certeza quanto à autoria do fato que frustrou a oportunidade, existindo incerteza quanto à existência/extensão dos danos". Já a teoria da perda de uma chance na seara médica, a "atividade do dano já está definida (a pessoa morreu), e o que resta saber é se esse dano teve como concausa a conduta do réu"194.

${ }^{193}$ STJ, REsp 1.254.141/PR, Rel. Min. Nancy Andrighi, julgado em 04.12.2012.
${ }^{194}$ MARTINS DE CASTRO, Alexandre; CASA MAIA, Maurilio. Op. Cit. p. 302. 
O referido acórdão trata de caso de aplicação da teoria da perda de uma chance em tratamento oncológico no qual o médico foi acusado de cometer diversos erros, tais como a falta de recomendação de quimioterapia à paciente; a mastectomia realizada foi parcial, quando seria recomendável a mastectomia radical, além de não ter sido transmitida à paciente a orientação para não engravidar. Foi dado provimento ao Recurso Especial para reduzir o quantum indenizatório para $80 \%$ do valor inicialmente estipulado, já que o valor da chance perdida deve ser sempre inferior ao valor do bem perdido.

A Ministra Nancy Andrighi assim se manifestou sobre o erro médico: “...a incerteza não está no dano experimentado, notadamente nas situações em que a vítima vem a óbito”, mas sim “... na participação do médico nesse resultado, à medida que, em princípio, o dano é causado por força da doença, e não pela falha do tratamento".

A Terceira Turma do STJ, portanto, estaria reconhecendo de forma implícita a teoria da perda de uma chance na seara médica como elemento de suavização do ônus da prova sobre o nexo causal, e, dessa forma, a facilitação da comprovação dos requisitos da responsabilidade civil ${ }^{195}$.

Nesse julgado, a perda de uma chance também foi reconhecida como dano autônomo. Assim dispôs o Ministro Ricardo Villas Boas Cueva no julgado:

"A chance perdida é um meio jurídico autônomo que não se confunde com o resultado que normalmente se indeniza quando há dano moral, por exemplo, e ela é aferível, sim, pelo princípio da causalidade, mas uma causalidade que utiliza já a estatística para aferir a probabilidade daquela chance perdida". Infere-se, portanto, que o dano da perda de uma chance é tratado como nova modalidade de dano, com uma nova análise da causalidade, que usa as probabilidades e estatísticas.

\section{Destaque-se também trecho do voto da Ministra Nancy Andrighi:}

“... a responsabilidade civil pela perda de uma chance, não atua, nem mesmo na seara médica, no campo da mitigação do nexo causal. A perda da chance, em verdade, consubstancia uma modalidade autônoma de indenização, passível de ser invocada nas hipóteses em que não se puder apurar a responsabilidade direta do agente pelo dano final. Nessas situações, o agente não responde pelo resultado para o qual sua conduta pode ter contribuído, mas apenas pela chance de que ele privou

${ }^{195}$ MARTINS DE CASTRO, Alexandre; CASAS MAIA, Maurilio. Op. Cit. p. 303. 
o paciente. Com isso, resolve-se, de maneira eficiente, toda a perplexidade que a apuração do nexo causal pode suscitar."

Em seu voto, a Relatora também sintetiza os pressupostos necessários pra aplicação da teoria da perda de uma chance, sendo necessário se fazer observar a presença ": (i) de uma chance concreta, real, com alto grau de probabilidade de obter um benefício ou sofrer um prejuízo; (ii) que a ação ou omissão do defensor tenha nexo causal com a perda da oportunidade de exercer a chance (sendo desnecessário que esse nexo se estabeleça diretamente com o objeto final); (iii) atentar para o fato de que o dano não é o benefício perdido, porque este é sempre hipotético."

Outro interessante caso que aqui merece ser apontado é o Recurso Especial $n^{\circ}$ 821.004-MG ${ }^{196}$, relatado pelo Ministro Sidnei Beneti. No caso, o autor, que concorria ao cargo de vereador do Município Carangola, em Minas Gerais, entrou com ação em face de empresa de rádio, pois, às vésperas do dia da eleição municipal, essa teria veiculado a falsa notícia de que sua candidatura havia sido cassada, não sendo eleito por apenas oito votos. Em primeira instância, o pedido foi julgado procedente e condenou-se a ré ao pagamento de indenização fixada em trinta salários mínimos a título de danos morais e $\mathrm{R} \$ 83.820,64$ a título de danos materiais, calculados com base no subsídio mensal de Vereador nos quatro anos de mandato. Em segunda

\footnotetext{
${ }^{196}$. STJ, REsp 821.004/MG, Rel. Ministro Sidnei Beneti, Terceira Turma, julgado em 19/08/2010, DJe 24/09/2010. Ementa: DIREITO CIVIL E PROCESSUAL CIVIL. RECURSO ESPECIAL. 1) NEGATIVA DE PRESTAÇÃO JURISDICIONAL AFASTADA. 2) PERDA DE CHANCE QUE GERA DEVER DE INDENIZAR. 3) CANDIDATO A VEREADOR, SOBRE QUEM PUBLICADA NOTÍCIA FALSA, NÃO ELEITO POR REDUZIDA MARGEM DE VOTOS. 4) FATO DA PERDA DA CHANCE QUE CONSTITUI MATÉRIA FÁTICA NÃO REEXAMINÁVEL PELO STJ. I.- Os Embargos de Declaração são corretamente rejeitados se não há omissão, contradição ou obscuridade no acórdão embargado, tendo a lide sido dirimida com a devida e suficiente fundamentação. II.- As Turmas que compõem a Segunda Seção desta Corte vêm reconhecendo a possibilidade de indenização pelo benefício cuja chance de obter a parte lesada perdeu, mas que tinha possibilidade de ser obtida III.- Aplica-se a teoria da perda de uma chance ao caso de candidato a Vereador que deixa de ser eleito por reduzida diferença de oito votos após atingido por notícia falsa publicada por jornal, resultando, por isso, a obrigação de indenizar. IV.- Tendo o Acórdão recorrido concluído, com base no firmado pelas provas dos autos, no sentido de que era objetivamente provável que o recorrido seria eleito vereador da Comarca de Carangola, e que esse resultado foi frustrado em razão de conduta ilícita das rádios recorrentes, essa conclusão não pode ser revista sem o revolvimento do conteúdo fático-probatório dos autos, procedimento vedado em sede de Recurso Especial, nos termos da Súmula 7 desta Corte. V.- Recurso Especial improvido. (grifo nosso).
} 
instância, o Tribunal reduziu o valor da indenização pelos danos materiais pela metade, aplicando a teoria da perda de uma chance. Entendeu o tribunal que a parte ré havia retirado sua chance de ser eleito vereador do município e que deveria receber o subsídio mensal referente ao cargo, mas "de forma proporcional à probabilidade da eleição", e, por isso, reduziu pela metade o montante dos danos materiais.

Desse modo, verifica-se que a Corte Superior entendeu não poder apreciar o caso devido à incidência da Súmula 7 do STJ, ou seja, o caso necessitava de análise do conteúdo fático-probatório, apesar de reconhecer que "era objetivamente provável que o recorrido seria eleito vereador da Comarca de Carangola e que esse resultado foi frustrado em razão de conduta ilícita das rádios recorrentes".

Sérgio Savi faz aprimorada análise sobre tal caso, afirmando que:

"Apesar de o TJMG ter julgado o caso adequadamente à luz da teoria da perda de uma chance, dependendo da prova que tenha sido produzida no curso da instrução, a conclusão final pode ter sido equivocada" ${ }^{197}$.

Savi assinala o fato do candidato não ter se elegido por apenas oito votos. Dessa forma, caso se conseguisse comprovar na instrução do processo, através de prova testemunhal, que de fato oito pessoas não votaram no candidato por conta da falsa notícia veiculada na rádio, o Doutrinador entende não ser caso de aplicação da teoria da perda de uma chance, devendo a vítima ser indenizada pelos lucros cessantes (ou seja, deveria receber o valor integral dos proventos de vereador durante mandato de quatro anos).

No entanto, caso não fosse possível fazer tal prova, ou seja, se, por exemplo, menos de oito testemunhas admitissem não ter votado no candidato somente por conta da falsa notícia sobre sua candidatura, correta está a aplicação da teoria da perda de uma chance no caso concreto.

${ }^{197}$ SAVI, Sérgio. Op. Cit., p. 93. 
Por fim, um dos mais recentes julgados em que a teoria da perda de uma chance é aplicada é o REsp n ${ }^{0} 1291247 / \mathrm{RJ}^{198}$, julgado em 19 de agosto de 2014. Trata-se de caso em que os autores firmaram contrato com empresa para a coleta e armazenagem de células-tronco embrionárias do seu futuro filho, que também figurou como demandante da ação. A data da cesariana foi comunicada à empresa que, contudo, não compareceu para a coleta do material contratado no dia do parto. Inconformados, os genitores pleitearam indenização pelos danos extrapatrimoniais sofridos.

O juízo de primeiro grau julgou o pedido parcialmente procedente, apenas para condenar a parte ré a pagar aos pais a quantia de $\mathrm{R} \$ 15.000,00$, pois entendeu não haver dano moral configurado no caso do menor, por conta de sua "tenra idade" e pela inocorrência da perda de uma chance. Em segunda instância, a decisão foi reformada apenas para majorar o valor da condenação devida aos pais, a título de danos morais. O REsp foi interposto, desse modo, apenas no nome do menor, pleiteando a indenização dos danos extrapatrimoniais embasada na teoria da perda de uma chance.

O Relator, Ministro Paulo de Tarso Sanseverino, considerou em seu voto que a criança foi a principal prejudicada pelo ato ilícito cometido pela empresa e entendeu restar configurada a responsabilidade civil pela perda de uma chance. Ressaltou o ministro que nesses casos não se exige a certeza do

\footnotetext{
${ }^{198}$ STJ, REsp 1291247/RJ, Rel. Ministro Paulo de Tarso Sansverino, Terceira Turma, julgado em 19/08/2014, DJe 01/10/2014.Ementa: RECURSO ESPECIAL. RESPONSABILIDADE CIVIL. PERDA DE UMA CHANCE.DESCUMPRIMENTO DE CONTRATO DE COLETA DE CÉLULAS-TRONCO EMBRIONÁRIAS DO CORDÃO UMBILICAL DO RECÉM NASCIDO. NÃO COMPARECIMENTO AO HOSPITAL. LEGITIMIDADE DA CRIANÇA PREJUDICADA. DANO EXTRAPATRIMONIAL CARACTERIZADO.1. Demanda indenizatória movida contra empresa especializada em coleta e armazenagem de células tronco embrionárias, em face da falha na prestação de serviço caracterizada pela ausência de prepostos no momento do parto.2. Legitimidade do recém-nascido, pois "as crianças, mesmo da mais tenra idade, fazem jus à proteção irrestrita dos direitos da personalidade, entre os quais se inclui o direito à integralidade mental, assegurada a indenização pelo dano moral decorrente de sua violação" (REsp. 1.037.759/RJ, Rel. Min. Nancy Andrighi, TERCEIRA TURMA, julgado em 23/02/2010, DJe 05/03/2010).3. A teoria da perda de uma chance aplica-se quando o evento danoso acarreta para alguém a frustração da chance de obter um proveito determinado ou de evitar uma perda.4. Não se exige a comprovação da existência do dano final, bastando prova da certeza da chance perdida, pois esta é o objeto de reparação.5. Caracterização de dano extrapatrimonial para criança que tem frustrada a chance de ter suas células embrionárias colhidas e armazenadas para, se for preciso, no futuro, fazer uso em tratamento de saúde.6. Arbitramento de indenização pelo dano extrapatrimonial sofrido pela criança prejudicda.7. Doutrina e jurisprudência acerca do tema.8. RECURSO ESPECIAL PROVIDO.
} 
dano final, bastando a certeza da chance perdida, ou seja, da certeza da probabilidade. Assim, o Ministro entendeu que:

"É possível que o dano final nunca venha a se implementar, bastando que a pessoa recém-nascida seja plenamente saudável, nunca desenvolvendo qualquer doença tratável com a utilização de células-tronco retiradas do cordão umbilical. O certo, porém, é que perdeu definitivamente a chance de prevenir o tratamento dessas patologias, sendo essa chance perdida o objeto da indenização"

Esse, entretanto, não foi o entendimento da Ministra Nancy Adrighi. Para a Ministra a teoria da perda de uma chance não poderia ser aplicada no caso em tela, assim fundamentando seu posicionamento:

“ A meu sentir, a análise do contexto fático, tal e qual descrito no acórdão impugnado, embora evidencie o inadimplemento contratual da recorrida - pelo qual, repita-se, foi condenada a indenizar os pais - não revela a certeza da probabilidade necessária à configuração do dano moral sofrido pelo recémnascido, senão apenas perda de uma possiblidade de tratamento se e somente se ele vier a contrair uma patologia ou correr tal risco e se essa patologia puder ser prevenida ou curada pelo uso das células-tronco, que deveriam ter sido coletadas e não o foram.

A conclusão, portanto, de que a recorrida, por negligência, interrompeu, definitivamente, a chance de o recorrente prevenir o tratamento de patologia grave, baseia-se, no meu entender, em premissas supostas, as quais, vale frisar, não refletem a realidade atual do menor, já que a probabilidade não se fazia presente no momento do fato lesivo"

"E mais, no campo das suposições, conviria até considerar a hipótese - não muito remota, aliás - de a medicina vir a descobrir outros meios para a coleta das células embrionárias, antes do recorrido vir a delas necessitar, o que reavivaria a expectativa de prevenção ou tratamento de eventual patologia e, por conseguinte, a chance inicialmente perdida, restando apenas o descumprimento do contrato". (grifo original)

A Ministra, todavia, foi voto vencido e a obrigação de indenizar foi estabelecida. A empresa ré foi condenada a pagar $\mathrm{R} \$ 60.000,00$ para o menor a título de danos morais.

Com a análise da jurisprudência, pode-se verificar que os tribunais brasileiros vêm aplicando a responsabilidade civil pela perda de uma chance, buscando adaptá-la ao nosso ordenamento, sem, no entanto, haver qualquer positivação acerca da teoria. Percebe-se que algumas particularidades da teoria permanecem controvertidas. 
A jurisprudência do Superior Tribunal de Justiça possui grande relevância na composição e harmonia do ordenamento jurídico infraconstitucional brasileiro. O tribunal é o responsável por pacificar e uniformizar a aplicação do direito federal em todo o país. À luz das informações contidas nos julgados acima analisados, podem-se destacar três principais funções da perda de uma chance no direito brasileiro: (i) uma nova modalidade de dano; (ii) "diferenciado critério probabilístico do nexo causal ligado ao dano à chance que solidariamente ameniza o ônus probatório da vítima..." e; (iii) mecanismo de quantificação indenizatória ${ }^{199}$.

${ }^{199}$ MARTINS DE CASTRO, Alexandre; CASAS MAIA, Maurilio. Op. Cit. p. 306. 


\section{Conclusão}

No cenário internacional, a teoria da perda de uma chance foi e vem sendo objeto de debate há anos, destacando-se aqui a doutrina francesa e italiana. Menciona-se ainda a doutrina americana que também reconheceu a tutela jurídica da chance perdida.

$\mathrm{Na}$ doutrina brasileira, a responsabilidade civil pela perda de uma chance foi objeto de estudo recentemente.

Inicialmente, muitas críticas foram feitas à teoria, por entender-se que a mesma tratava de hipótese de indenização por dano hipotético e eventual. Além disso, outro óbice seria a impossibilidade de se quantificar a indenização decorrente da chance perdida.

A teoria, contudo, cada vez mais é debatida com maior profundidade e aplicada pelos tribunais. Os seus principais aspectos foram abordados neste ensaio, como a natureza jurídica da chance perdida, se dano emergente ou lucro cessante, ou ainda se dano moral ou material. Foi concluído que a perda de uma chance pode acarretar danos materiais e danos morais, cumulativamente ou não, embora a tendência dos tribunais seja condenar a chance perdida apenas como dano moral.

Viu-se ainda o entendimento que considera o dano decorrente da chance perdida como uma terceira categoria lesiva, entre o dano emergente e o lucro cessante.

No caso da chance perdida acarretar dano de natureza patrimonial, parece que o melhor entendimento é aquele que a considera dano emergente, pois a chance já pertencia ao patrimônio da vítima antes do evento danoso e dessa forma, elimina-se o problema da certeza do dano. "Ou seja, não estamos diante de uma hipótese de lucros cessantes em razão da vitória futura que restou frustrada, mas de um dano emergente em razão da atual possibilidade de vitória que deixou de existir" ${ }^{200}$.

200 SAVI, Sérgio. Op. Cit., p. 122. 
Outra questão relevante e de opinião unívoca na doutrina, é que indeniza-se a própria chance perdida e não a vantagem final que era esperada, o que é utilizado também como critério para quantificação da indenização.

Analisou-se, nesse passo, a jurisprudência nacional acerca do assunto, com enfoque no Superior Tribunal de Justiça, que tem a importante função de uniformizar a interpretação da Lei Federal e vem proferindo diversos precedentes. Verificou-se que o STJ considera a chance perdida como dano autônomo. Porém, para tanto, exige-se que tal chance seja séria e real para ser indenizável.

Convém ressaltar ainda, que a teoria da perda de uma chance não está positivada no ordenamento pátrio, fato este que decorre provavelmente do descompasso entre a evolução das relações sociais e da legislação. Nesse ponto, Maria Celina Bodin de Moraes faz importante consideração, digna de menção, sobre como o direito da responsabilidade civil "é antes de tudo jurisprudencial"201. Explica-se que os magistrados são os primeiros a sentirem as mudanças sociais e frente às novas controvérsias jurídicas, dãolhes respostas normativas, enquanto o legislativo mantém-se inerte.

\footnotetext{
"Mas isto somente ocorre porque o mecanismo da responsabilidade civil é composto, em sua maioria, por cláusulas gerais e por conceitos vagos e indeterminados, carecendo de preenchimento pelo juiz a partir do exame do caso concreto. Com a incidência dos princípios e valores constitucionais se faz, em via mediata, justamente desta maneira, através do preenchimento valorativo desses conceitos, vê-se que a constitucionalização responsabilidade civil pode se dar naturalmente" 202 .
}

Nesse prisma, insere-se a responsabilidade pela perda de uma chance, que a despeito de não possuir previsão legal especifica não encontra óbice para sua aceitação no Direito brasileiro.

Conforme observado, são pressupostos da responsabilidade civil a conduta, o dano e o nexo de causalidade. Na perda de uma chance, tais

\footnotetext{
${ }^{201}$ MORAES, Maria Celina Bodin de. Op cit. p. 238.

202 Ibid., p. 239.
} 
elementos estão presentes, sendo o nexo de causalidade entre a conduta e o dano da chance perdida e não entre o dano final.

Em alguns casos, quando o processo aleatório transcorre até o fim e não é interrompido, a responsabilidade civil pela perda de uma chance será fundada na causalidade parcial. Em que pese ser uma exceção ao sistema brasileiro de utilização do nexo causal, representa uma solução mais justa e adequada, devendo ser usada como opção subsidiária. Nas palavras de Peteffi da Silva, “...não depende de uma desvirtuação do nexo causal, mas de uma evolução deste" 203 .

Além disso, a cláusula geral de responsabilidade civil, que torna o conceito de dano aberto, podendo ser inserido o dano da chance perdida e o princípio da reparação integral dos danos, tornam compatível a teoria da perda de uma chance com o ordenamento jurídico brasileiro.

Em virtude dessas considerações, impende ressaltar que a técnica de reparação de chances constitui uma evolução da responsabilidade civil, em consonância com os princípios constitucionais. A vítima que sofre lesão a seu interesse jurídico não pode restar desamparada. A álea e a incerteza deixam de representar um obstáculo à aplicação da responsabilidade civil e os interesses aleatórios passam a ser protegidos de forma salutar.

${ }^{203}$ SILVA, Rafael Peteffi da. Op. Cit p. 259. 


\section{Referências Bibliográficas}

AGUIAR DIAS, José de. Da Responsabilidade Civil. 12a Edição. Rio de Janeiro: Editora Lumen Juris, 2012.

ALVIM, Agostinho Neves de Arruda. Da inexecução das obrigações e suas consequências. $4^{\text {a }}$ Edição. São Paulo: Saraiva, 1972.

CARNAÚBA, Daniel Amaral. Responsabilidade Civil pela Perda de uma Chance: a álea e a técnica. São Paulo: Método, 2013.

CARVAlHO SANTOS, J. M. de. Código Civil Brasileiro Interpretado: principalmente sobre o ponto de vista prático, $11^{\text {a }}$ Edição. Rio de Janeiro: Freitas Bastos, $1964-\mathrm{v}$.

CAVAlIERI FILHO, Sérgio. Programa de Responsabilidade Civil. 9a Edição. São Paulo: Atlas, 2010.

DIAS, Sergio Novais. Responsabilidade Civil do Advogado. São Paulo: Ltr, 1999.

DINIZ, Maria Helena. Curso de Direito Civil Brasileiro - Responsabilidade Civil. 17ª Edição. São Paulo: Saraiva, 2003. VII.

KFOURI NETO, Miguel. Culpa Médica e Ônus Prova: presunções, perda de uma chance, cargas probatórias dinâmicas, inversão do ônus probatório e consentimento informado: responsabilidade civil em pediatria, responsabilidade civil em gineco-obstetrícia. São Paulo: Editora Revista dos Tribunais, 2002. 
MARTINS COSTA, Judith. Comentários ao Novo Código Civil, v. V, tomo II: Do inadimplemento das Obrigações, coord. Sálvio Figueiredo Teixeira, Rio de Janeiro: Editora Forense, 2003.

MARTINS DE CASTRO, Alexandre; CASAS MAIA, Maurilio. A Responsabilidade Civil pela Perda de uma Chance de Cura ou Sobrevivência na Atividade Médica: Entre a Doutrina e a visão do Superior Tribunal de Justiça. In Revista de Direito do Consumidor. Ano 23. Vol. 95. Setembro/ Outubro 2014. Coordenação Claudia Lima Marques.

MORAES, Maria Celina Bodin de. A constitucionalização do Direito Civil e seus efeitos sobre a Responsabilidade Civil. In: SOUZA NETO, Cláudio Pereira de; SARMENTO, Daniel (orgs). A constitucionalização do direito. Fundamentos Teóricos e aplicações especificas. Rio de Janeiro: Lumen Juris, 2007. Disponível em $<$ http://www.estig.ipbeja.pt/ ac_direito/Bodin_n29.pdf $>$ :

MORAES, Maria Celina Bodin de. Danos à pessoa humana: uma leitura civil-constitucional dos danos morais. Rio de Janeiro: Renovar, 2009.

NORONHA, Fernando. Direito das Obrigações: fundamentos do direito das obrigações: introdução à responsabilidade civil. v.1, São Paulo: Saraiva, 2003.

PEREIRA, Caio Mário da Silva. Responsabilidade Civil. Rio de Janeiro; 9a Edição. Rio de Janeiro: Forense, 2002.

RODRIGUES, Silvio. Direito Civil v. IV, $17^{\text {a }}$ Edição. São Paulo: Saraiva, 1999.

SAVI, Sérgio. Responsabilidade Civil pela Perda de uma Chance. $3^{\text {a }}$ Edição, São Paulo: Atlas, 2012. 
SERPA LOPES, Miguel Maria de. Curso de Direito Civil, v.II: Obrigações em Geral. $7^{\text {a }}$ Edição. Revista e atualizada pelo Prof. José Serpa Santa Maria, Rio de Janeiro: Freitas Bastos, 2000, -v

SILVA, Rafael Peteffi da. Responsabilidade Civil Pela Perda de uma Chance: uma análise do direito comparado e brasileiro. $3^{\text {a }}$ Edição. São Paulo: Atlas, 2013.

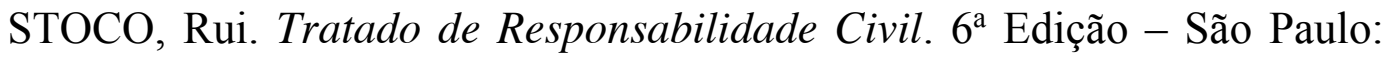
Editora Revista dos Tribunais, 2004.

STJ, REsp 57.529/DF, Rel. Min. Ruy Rosado de Aguiar, Quarta Turma, Brasília, 07 de nov. de 1995

STJ, Agravo Regimental no 272.635/SP, Rel. Min. Eduardo Ribeiro, Brasília, 11 de fev. de 2000

STJ, REsp 788.459/BA, Rel. Min. Fernando Gonçalves, Quarta Turma, Brasília, 08 de nov. de 2005

STJ, REsp 1079185/MG, Rel. Min. Nancy Andrighi, Terceira Turma, Brasília, 11 de nov. de 2008

STJ, REsp 1104665/RS, Rel. Min. Massami Uyeda, Terceira Turma, Brasília, 09 de junho de 2009.

STJ, REsp 1190180/RS, Rel. Min. Luis Felipe Salomão, Quarta Turma, Brasília, 16 de nov. de 2010 
STJ, REsp 821.004/MG, Rel. Min. Sidnei Beneti, Terceira Turma, Brasília, 19 de agosto de 2010.

STJ, REsp 1115687/SP, Rel. Ministra Nancy Andrighi, Terceira Turma, Brasília, 18 de nov de 2011

STJ, EDcl no AgRg no Ag 1196957/DF, Rel. Min. Maria Isabel Galloti, Quarta Turma, Brasília, 10 de abril de 2012.

STJ, REsp 1.254.141/PR, Rel. Min. Nancy Andrighi, Brasília, 04 de nov. de 2012 .

STJ, REsp 1291247/RJ, Rel. Ministro Paulo de Tarso Sansverino, Terceira Turma, Brasília, 19 de agosto de 2014

Tribunal de Justiça do Rio de Janeiro, Sexta Câmara Cível, Apelação Cível 2003.001.16559, Rel. Des. Pestana de Aguiar, Rio de Janeiro, 17 de set. de 2009

Tribunal de Justiça do Rio de Janeiro, 14ª Câmara Cível, Apelação Cível 2003.001.19138, Rel. Des. Ferdinaldo do Nascimento, Rio de Janeiro, 07 de out. de 2003.

Tribunal de Justiça do Rio Grande do Sul, $5^{\text {a }}$ Câmara Cível, Apelação Cível 589069996, Rel. Des. Ruy Rosado de Aguiar Júnior, Porto Alegre, 12 de junho de 1990.

Tribunal de Justiça do Rio Grande do Sul, $5^{\text {a }}$ Câmara Cível, Apelação Cível 591064837, Rel. Des. Ruy Rosado de Aguiar Júnior, Porto Alegre, 29 de agosto de 1991. 
Tribunal de Justiça do Rio Grande do Sul, 2a Câmara Especial Cível, Apelação Cível 70004650305, Rel. Des. Mário Crespo Brum, Porto Alegre, 19 de dez. de 2002

Tribunal de Justiça do Rio Grande do Sul, $6^{\text {a }}$ Câmara Cível, Apelação Cível № 70005635750, Rel. Des. Carlos Alberto Alvaro de Oliveira, Porto Alegre, 17 de set. de 2009

Tribunal de Justiça do Rio Grande do Sul, $10^{a}$ Câmara Cível, Apelação Cível 70006606487, Rel. Des. Paulo Antônio Kretzmann, Porto Alegre, 06 de nov. de 2003

Tribunal de Justiça do Rio Grande do Sul, Primeira Turma Recursal Cível, Turmas Recursais, Recurso Cível No 71001196195, Rel. Des. Ricardo Torres Hermann, Porto Alegre, 12 de julho de 2007

Tribunal de Justiça de São Paulo, $6^{\text {a }}$ Câmara de Direito Privado, Apelação Cível 9176724-03.2000.8.29.0000, Rel. Des. Ministro Sebastião Carlos Garcia, São Paulo, 23 de nov. de 2004

Tribunal de Justiça de São Paulo, $35^{\text {a }}$ Câmara de Direito Privado, Apelação Cível 9163372-31.2007.8.26.0000, Rel. Des. Manoel Justino Bezerra Filho, São Paulo, 18 de out. de 2010.

Tribunal de Justiça de São Paulo, 27 Câmara de Direito Privado, Apelação Cível 0034387-12.2008.8.26.0309, Rel.Des. Dilmas Rubens Fonseca, São Paulo, 05 de abril de 2011.

VENOSA, Sílvio de Salvo. Direito civil: responsabilidade civil. $6^{a}$ Edição. V.4 São Paulo: Atlas, 2006. 


\section{Pontifícia Universidade Católica $_{\text {a }}$ \\ DO RIO DE JANEIRO}

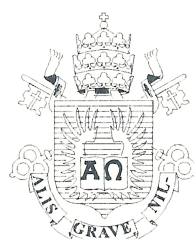

\section{NORMAS PARA ELABORAÇÃO E APRESENTAÇÃO DA MONOGRAFIA JUR 1919 ou JUR 1916}

\section{ANEXO II \\ A Monografia deve ser entregue até o dia 4 de novembro de 2014.}

A presente Monografia, apresentada pelo (a) aluno (a)_Bmma Gabsielle Marmi rezende

ser submetida à exposição e defesa perante a Banca Examinadora designada pelo Departamento de Direito da PUC-Rio.

Rio de Janeiro, 81 de Qutubwde 2014.

Marcelo Calixto

Nome do (a) professor (a) orientador (a)

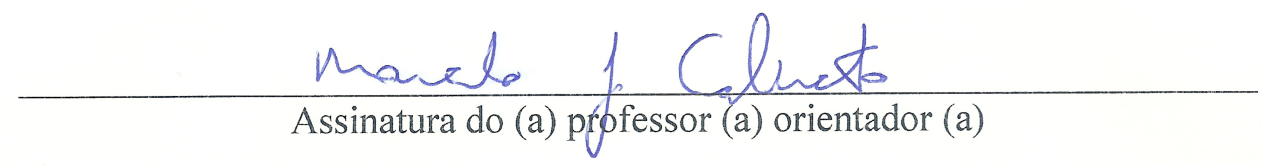

O (A) autor (a) declara para todos os fins de Direito ser este um trabalho inédito de sua autoria e autoriza o Departamento de Direito da PUC-Rio a divulgá-lo, no todo ou em parte, resguardados os direitos autorais conforme legislação vigente.

Rio de Janeiro, 04 de noven be 2014.

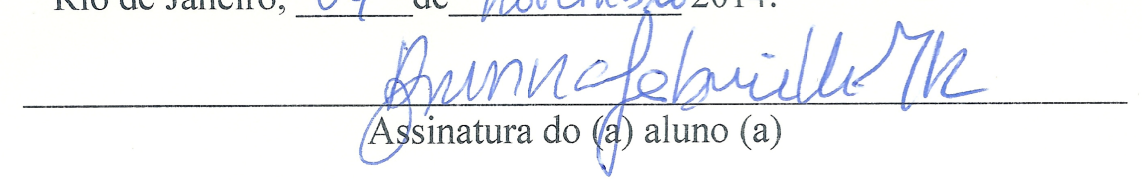

